UNIVERSIDADE DE SÃO PAULO

FACULDADE DE FILOSOFIA, CIÊNCIAS E LETRAS DE RIBEIRÃO PRETO-USP

DEPARTAMENTO DE PSICOLOGIA

PROGRAMA DE PÓS-GRADUAÇÃO EM PSICOLOGIA

Ana Carolina Fortes Paiva de Pina

Dinâmica psíquica familiar de adolescentes com obesidade

Ribeirão Preto 
ANA CAROLINA FORTES PAIVA DE PINA

\section{Dinâmica psíquica familiar de adolescentes com obesidade}

\section{Versão original}

Dissertação apresentada à Faculdade de Filosofia, Ciências e Letras de Ribeirão Preto da Universidade de São Paulo para a obtenção do título de Mestre em Ciências.

Área de concentração: Psicologia em Saúde e Desenvolvimento.

Orientadora: Prof ${ }^{\mathrm{a}} \mathrm{Dr}^{\mathrm{a}}$ Valeria Barbieri 
Autorizo a reprodução e divulgação total ou parcial deste trabalho, por qualquer meio convencional ou eletrônico, para fins de estudo e pesquisa, desde que citada a fonte.

\section{FICHA CATALOGRÁFICA}

Pina, Ana Carolina Fortes Paiva de

Dinâmica psíquica familiar de adolescentes com obesidade. Ribeirão Preto, 2021.

312 p. : il. ; $30 \mathrm{~cm}$

Dissertação de Mestrado apresentada à Faculdade de Filosofia, Ciências e Letras de Ribeirão Preto, Universidade de São Paulo - USP. Área de concentração: Psicologia em Saúde e Desenvolvimento.

Orientadora: Prof. ${ }^{\text {a }}$ Dr. ${ }^{\text {a }}$ Barbieri, Valeria

1. Família 2. Obesidade 3. Adolescência 4. Psicanálise 5. Transmissão psíquica entre gerações 
Nome: Pina, Ana Carolina Fortes Paiva de

Título: Dinâmica psíquica familiar de adolescentes com obesidade

Dissertação apresentada à Faculdade de Filosofia, Ciências e Letras de Ribeirão Preto da Universidade de São Paulo para a obtenção do título de Mestre em Ciências. Área de concentração: Psicologia em Saúde e Desenvolvimento.

Aprovado em:

\section{Banca Examinadora}

Prof. Dr.

Instituição:

Julgamento:

Prof. Dr.

Instituição:

Julgamento:

Prof. Dr.

Instituição:

Julgamento:

Prof. Dr.

Instituição:

Julgamento: 


\section{Apoio financeiro:}

Este trabalho foi financiado pela Coordenação de Aperfeiçoamento de Pessoal de Nível Superior (CAPES), mediante concessão de bolsa de Mestrado, no período de março de 2017 a março de 2019.

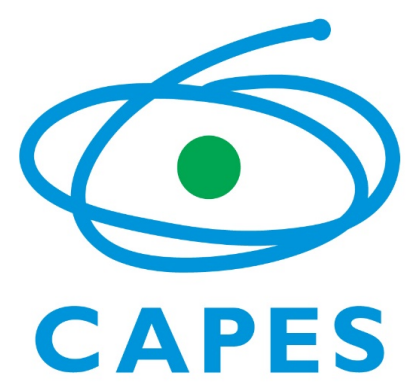


Numa incerta hora fria perguntei ao fantasma que força nos prendia, ele a mim, que presumo estar livre de tudo, eu a ele, gasoso, todavia palpável na sombra que projeta sobre meu ser inteiro: um ao outro, cativos desse mesmo princípio ou desse mesmo enigma que distrai ou concentra e renova e matiza, prolongando-a no espaço uma angústia do tempo.

Perguntei-lhe em seguida o segredo de nosso convívio sem contato, de estarmos ali quedos, eu em face do espelho, e o espelho devolvendo uma diversa imagem, mas sempre evocativa do primeiro retrato que compõe de si mesma a alma predestinada a um tipo de aventura terrestre, cotidiana.

Perguntei-lhe por fim a razão sem razão de me inclinar aflito sobre restos de restos, de onde nenhum alento vem refrescar a febre desse repensamento: sobre esse chão de ruínas imóveis, militares na sua rigidez que o orvalho matutino já não banha ou conforta.

No vôo que desfere, silente e melancólico, rumo da eternidade ele apenas responde (se acaso é responder a mistérios, somar-lhes um mistério mais alto):

Amar depois de perder.

(Carlos Drummond de Andrade, Perguntas) 


\section{AGRADECIMENTOS}

Caminho e atrás de mim caminham as estrelas até seu próximo amanhã o segredo, a morte, o que nasce, o cansaço amortecem meus passos, avivam meu sangue.

Não iniciei a trilha, ainda não vejo nenhum jazigo caminho até mim mesmo, até meu próximo amanhã caminho e atrás de mim caminham as estrelas.

(Adonis)

Este trabalho foi feito ao longo de anos presenteados por muitos desafios. Sou hoje uma pesquisadora graças a uma trajetória de arrebatamento com a mente humana, especialmente a minha própria. Graças a uma relação complicada e muito apaixonada com o conhecer e o não saber, que avivam meu sangue, tenho estudado, pesquisado e questionado. Se por um lado é o que me intriga e me faz viver, também é a nascente de uma angústia sem medida e da minha inquietude cotidiana. Morar em mim não seria possível, se não me habitassem também todas as minhas estrelas, minha preciosa constelação.

Agradeço a todos que me ajudaram a confiar no que sinto e, com seu brilho, iluminaram meu caminho. Agradeço àqueles que confiaram em mim e, por vezes, apagaram as luzes.

À Clara, dedico estes pensamentos, que surgiram antes dela, mas junto a ela puderam ser gestados.

Ao Cassio, dedico todas estas palavras, cada uma escrita com o amparo do nosso amor.

À Valeria, dedico esta pesquisa, nutrida com sua receptividade, paciência e doçura, sua capacidade de ensinar, de esperar e se entusiasmar com o que pude realizar em meus limites.

À Marta, dedico estes sentimentos, os que transbordaram daqui e os que puderam ficar, criando o que escrevi e os espaços em branco.

À minha mãe, dedico estas emoções; dedico a força, o amor e a intensidade que estão nestas páginas. 
Agradeço aos meus avós e antepassados, os que conheci e que não conheci, pelos enigmas que me propõem e por tudo aquilo que desejaram eternizar, e hoje me compõe.

Agradeço a toda a minha família, pela condição que tenho de sentir em mim o que é ter uma família. Agradeço às estrelas do céu e às da terra, origens do amor em mim.

Agradeço à Camila e à Sofia, que me ensinaram que em meio às bagunçadas transmissões geracionais existe lugar para as ternas memórias e muito espaço para a criação.

Aos meus amigos, agradeço por não serem a minha família; e por serem, sim, uma família para mim. Àqueles que me diversificam, que comigo têm compartilhado companhia, casa, brincadeiras e sonhos.

Agradeço às famílias participantes desta pesquisa e aos jovens que as instigam. Agradeço também aos colegas e instituições que me ajudaram na árdua caminhada em busca de encontrá-los.

Aos membros da minha banca de qualificação, Luciana Torrano e Fernanda Mishima Gomes, agradeço pelo olhar generoso e pelas valiosas contribuições.

Aos membros do Laboratório de Avaliação Psicológica Infantil, Adolescente, Adulto e Familiar, por compartilharmos conhecimentos, dúvidas, interesses e até mesmo as terríveis burocracias.

À Coordenação de Aperfeiçoamento de Pessoal de Nível Superior (CAPES) agradeço pela concessão da bolsa de Mestrado e pelo incentivo à pesquisa em psicanálise.

Ao prazo final de entrega desta dissertação, agradeço por ter sido esse horizonte inexorável, que inspirou agilidade ao meu pensamento.

A todos os autores que de alguma forma orientaram este trabalho com suas teorias, pesquisas e seus questionamentos, cada um com seu brilhante caminho.

Ao que em mim persiste. 


\section{RESUMO}

Pina, A. C. F. P. de (2021). Dinâmica psíquica em famílias de adolescentes com obesidade. (Dissertação de Mestrado). Faculdade de Filosofia, Ciências e Letras de Ribeirão Preto, Universidade de São Paulo, São Paulo.

A obesidade é um problema crítico de saúde pública no Brasil e no mundo. Apresenta-se frequentemente como fonte de sofrimento físico e emocional, e seu caráter multifatorial torna a compreensão desta patologia um desafio contemporâneo. Estudos vinculam a sustentação da obesidade na infância e na adolescência, dentre outras hipóteses, a disfunções nas relações familiares e a dificuldades no processo de subjetivação do indivíduo, decorrentes de uma indiferenciação em relação a seus objetos primordiais. Diante dessas considerações, esta pesquisa teve como objetivo conhecer o funcionamento psíquico de famílias de adolescentes obesos, com o propósito de investigar se as relações intersubjetivas familiares e a constituição da imagem inconsciente do corpo familiar poderiam contribuir para o surgimento e a manutenção dessa patologia no jovem. A pesquisa foi realizada numa perspectiva clínicoqualitativa, utilizando dois instrumentos projetivos desenvolvidos para a avaliação psicológica familiar, a Espaciografia Projetiva e a Genografia Projetiva, e entrevistas semiestruturadas acerca da história familiar, hábitos alimentares e do habitat familiar. A codificação das técnicas projetivas teve como referência os guias propostos em seus manuais e os dados coletados foram organizados em sínteses interpretativas a partir de uma perspectiva clínica psicanalítica. Os resultados evidenciaram a presença de dinâmicas fusionais, relacionamentos simbióticos e indiferenciação entre os membros das famílias, especialmente entre mães e filhos. $\mathrm{O}$ distanciamento ou enfraquecimento da figura do pai também foi observado em todos os casos, assim como um afastamento da família em relação ao mundo externo, confirmando dados da literatura. Além disso, observou-se em todas as famílias um esforço grupal de suprimir das experiências da vida os limites da morte, numa recusa inconsciente a viverem a perda de seus objetos de amor. Cria-se um pacto familiar em que a dissolução dos objetos é impedida, inviabilizando movimentos psíquicos imprescindíveis ao processo de subjetivação. Há uma paralização dos objetos e um movimento de incorporação que os inclui de forma não transformável dentro da mente dos indivíduos. Os processos de simbolização e representação são gravemente perturbados, ocorrendo o predomínio de modos de relacionamento que primam pela inércia e o sedentarismo, como a aglutinação, a contiguidade e a aderência. Revelou-se nas famílias uma exclusão da experiência da perda, e as denegações necessárias a este processo levam à criação de criptas, as quais são transmitidas às gerações seguintes, provocando uma alienação da subjetividade dos indivíduos. Estes se tornam submissos às demandas ancestrais, cuja penalidade para a desobediência é o exílio e a perda do amor da família. A relação entre indivíduos é, então, substituída por um vínculo de cada um dos membros da família com um núcleo aglutinado. Os indivíduos devem alimentar essa relação com o núcleo familiar, atuando em repetições os mandatos identitários para que seja preservada a ilusão de uma unidade fusional. A esse conjunto de ações psíquicas, denominamos pacto denegativo familiar do trabalho do negativo.

Palavras-chave: família, obesidade, adolescência, psicanálise, transmissão psíquica entre gerações. 


\begin{abstract}
Pina, A. C. F. P. de (2021). Family psychodynamics of adolescents with obesity. (Dissertação de Mestrado). Faculdade de Filosofia, Ciências e Letras de Ribeirão Preto, Universidade de São Paulo, São Paulo.

Obesity is a critical public health problem in Brazil and worldwide. It often presents itself as a source of physical and emotional suffering, and its multifactorial causation makes its comprehension a contemporary challenge. Studies link the emergence of obesity in childhood and adolescence to dysfunctions in family relations and difficulties in the subjectivation process, due to undifferentiation regarding its primordial objects. Given these considerations, this research aimed to understand the psychic functioning of families of obese teenagers, with the purpose of investigating whether intersubjective family relationships and the constitution of the unconscious image of the family body could contribute to the emergence and maintenance of this pathology in the youngster. The research was carried out in a clinicalqualitative perspective, utilizing two projective instruments oriented for the psychological evaluation of the family, namely the Projective Spatiography and the Projective Genography, as well as semi-structured interviews about family history, eating habits and family habitat. The codification of the projective techniques was based on the guides proposed in their manuals, and the collected data were organized in interpretative syntheses from a psychoanalytic clinical perspective. Results showed a presence of states of fusion, symbiotic relationships and undifferentiation between family members, specially between mothers and children. The distancing or weakening of the father figure was also observed in all cases, as well as seclusion from the external world, confirming data from literature. Furthermore, a group effort was observed in all families to suppress the boundaries of death from the experiences of life, in an unconscious refusal to undergo the loss of their objects. A family pact is created in which the dissolution of objects is blocked, rendering unviable the psychic processes that are essential to subjectivation. The objects are paralyzed and incorporated in a non-transformable form within the individuals' minds. Capacities for symbolization and representation are severely disturbed. Forms of relation prevail in which inertia and sedentarism are found, such as agglutination, contiguity and adherence. An exclusion of the experience of loss was revealed in these families, and the denial which is necessary to this process led to the creation of crypts, which are passed on to subsequent generations, causing alienation of the individuals' subjectivity. They become submissive to these ancestral demands, and the penalty for disobedience is exile and deprivation of family love. Thus, the relationship between family members is replaced by an unique bond with an agglutinated nucleus. The individuals are compelled to encourage this relationship with the family nucleus, acting in repetition the mandates of their ancestors so that the illusion of a fusional unity is preserved. We denominated this set of psychic actions as a family denegative pact for the work of the negative.
\end{abstract}

Key-words: family, obesity, adolescence, psychoanalysis, psychic transmission between generations. 


\section{LISTA DE ILUSTRAÇÕES}

Figura 1 - Desenho da Árvore Genealógica da família de Pedro.............................................81

Figura 2 - Desenho da Casa dos Sonhos da família de Pedro....................................................95

Figura 3 - Desenho da Árvore Genealógica da família de Camila.........................................116

Figura 4 - Desenho da Casa dos Sonhos da família de Camila...............................................129

Figura 5 - Desenho da Árvore Genealógica da família de Diego............................................153

Figura 6 - Desenho da Casa dos Sonhos da família de Diego...............................................165

Figura 7 - Desenho da Árvore Genealógica da família de Marina..........................................183

Figura 8 - Desenho da Casa dos Sonhos da família de Marina................................................192 


\section{LISTA DE TABELAS}

Tabela 1 - Codificação do desenho da árvore genealógica da família de Pedro..........................83

Tabela 2 - Codificação do desenho da casa dos sonhos da família de Pedro..............................98

Tabela 3 - Codificação do desenho da árvore genealógica da família de Camila.....................116

Tabela 4 - Codificação do desenho da casa dos sonhos da família de Camila..........................129

Tabela 5 - Codificação do desenho da árvore genealógica da família de Diego.......................153

Tabela 6 - Codificação do desenho da casa dos sonhos da família de Diego............................165

Tabela 7 - Codificação do desenho da árvore genealógica da família de Marina......................183

Tabela 8 - Codificação do desenho da casa dos sonhos da família de Marina..........................192 


\section{SUMÁRIO}

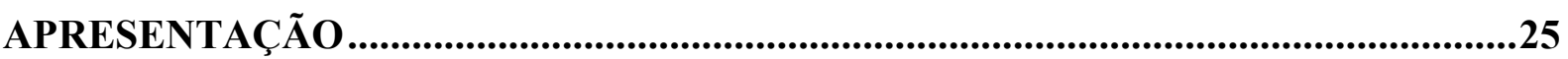

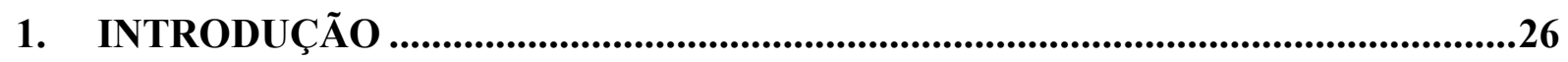

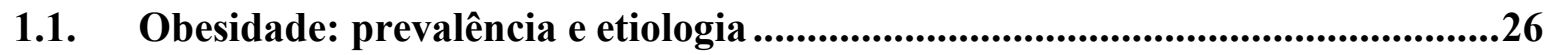

1.2. Obesidade na infância e na adolescência.........................................................28

1.3. A família e a obesidade do adolescente .......................................................30

1.4. A intersubjetividade na constituição do psiquismo ...........................................33

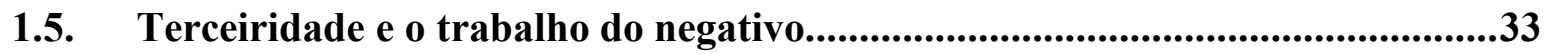

1.6. Alianças inconscientes.................................................................................................33

1.7. Transmissão psíquica geracional........................................................................33

1.8. Imagem inconsciente do corpo familiar e obesidade do adolescente..................33

2. JUSTIFICATIVA ......................................................................................................35

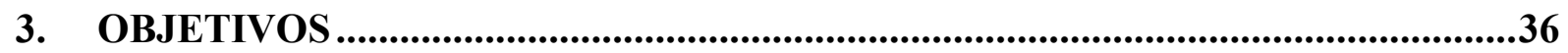

3.1. Objetivo geral....................................................................................................36

3.2. Objetivos específicos ............................................................................................36

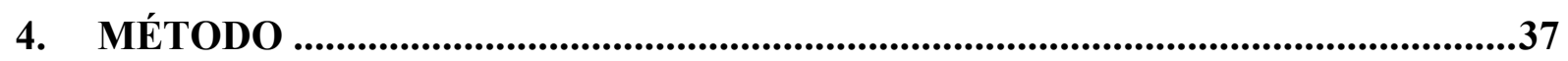

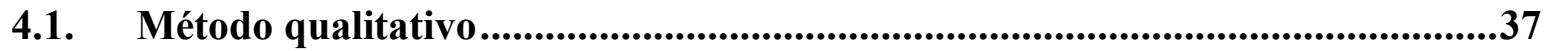

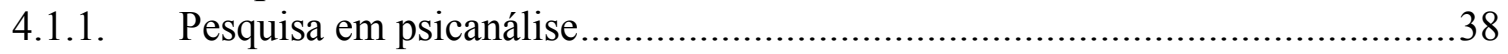

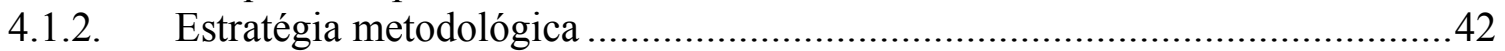

4.1.3. Técnicas projetivas na pesquisa psicanalítica .......................................... 42

4.2. Participantes ............................................................................................43

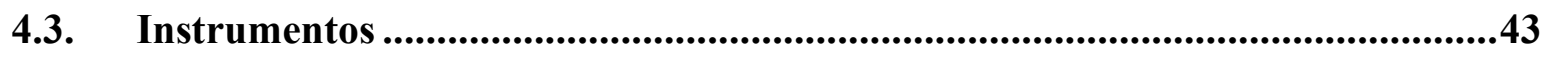

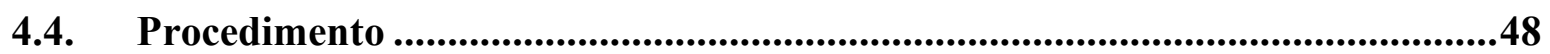

4.5. Análise de dados........................................................................................49

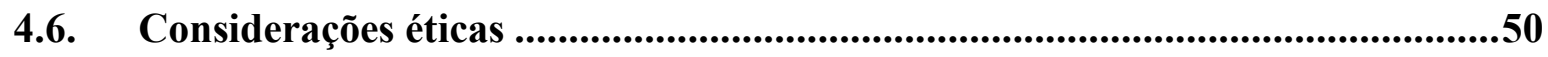

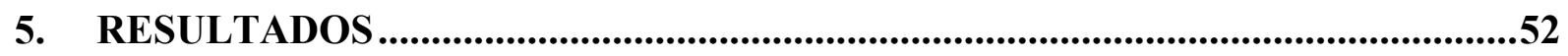

5.1. Família de Pedro ........................................................ Erro! Indicador não definido. 5.1.1. Apresentação................................................. Erro! Indicador não definido.

5.1.2. Entrevista sobre a História Familiar e Hábitos AlimentaresErro! Indicador não definido.

5.1.2.1. Síntese da entrevista Erro! Indicador não definido.

5.1.2.2. Análise da entrevista ................................. Erro! Indicador não definido.

5.1.3. Genografia Projetiva Familiar ......................... Erro! Indicador não definido.

5.1.3.1. Desenho da Ârvore Genealógica.................... Erro! Indicador não definido.

5.1.3.2. Inquérito...................................................... Erro! Indicador não definido.

5.1.3.3. Codificação do desenho da árvore genealógicaErro! Indicador não definido.

5.1.3.4. Análise da Genografia Projetiva Familiar ..... Erro! Indicador não definido.

5.1.4. Entrevista sobre o Habitat Familiar.................... Erro! Indicador não definido. 
5.1.4.1. Síntese da entrevista .................................... Erro! Indicador não definido.

5.1.4.2. Análise da entrevista ................................. Erro! Indicador não definido.

5.1.5. Espaciografia Projetiva Familiar...................... Erro! Indicador não definido.

5.1.5.1. Desenho da Casa dos Sonhos........................ Erro! Indicador não definido.

5.1.5.2. Inquérito.................................................... Erro! Indicador não definido.

5.1.5.3. Codificação do desenho da casa dos sonhos.. Erro! Indicador não definido.

5.1.5.4. Análise da Espaciografia Projetiva Familiar . Erro! Indicador não definido.

5.1.6. Síntese da família de Pedro ............................. Erro! Indicador não definido.

5.2. Família de Camila ...................................................... Erro! Indicador não definido.

5.2.1. Apresentação................................................... Erro! Indicador não definido.

5.2.2. Entrevista sobre a História Familiar e Hábitos AlimentaresErro! Indicador não definido.

5.2.2.1. Síntese da entrevista

Erro! Indicador não definido.

5.2.2.2. Análise da entrevista Erro! Indicador não definido.

5.2.3. Genografia Projetiva Familiar

Erro! Indicador não definido.

5.2.3.1. Desenho da Árvore Genealógica......

Erro! Indicador não definido.

5.2.3.2. Inquérito.

Erro! Indicador não definido.

5.2.3.3. Codificação do desenho da árvore genealógicaErro! Indicador não definido.

5.2.3.4. Análise da Genografia Projetiva Familiar ...... Erro! Indicador não definido.

5.2.4. Entrevista sobre o Habitat Familiar.................... Erro! Indicador não definido.

5.2.4.1. Síntese da entrevista .................................... Erro! Indicador não definido.

5.2.4.2. Análise da entrevista ................................. Erro! Indicador não definido.

5.2.5. Espaciografia Projetiva Familiar.......................... Erro! Indicador não definido.

5.2.5.1. Desenho da Casa dos Sonhos........................ Erro! Indicador não definido.

5.2.5.2. Inquérito................................................... Erro! Indicador não definido.

5.2.5.3. Codificação do desenho da casa dos sonhos.. Erro! Indicador não definido.

5.2.5.4. Análise da Espaciografia Projetiva Familiar. Erro! Indicador não definido.

5.2.6. Síntese da família de Camila ............................ Erro! Indicador não definido.

5.3. Família de Diego ...................................................... Erro! Indicador não definido.

5.3.1. Apresentação.................................................. Erro! Indicador não definido.

5.3.2. Entrevista sobre a História Familiar e Hábitos AlimentaresErro! Indicador não definido.

5.3.2.1. Síntese da entrevista

Erro! Indicador não definido.

5.3.2.2. Análise da entrevista Erro! Indicador não definido.

5.3.3. Genografia Projetiva Familiar Erro! Indicador não definido.

5.3.3.1.

Desenho da Árvore Genealógica.

Erro! Indicador não definido.

5.3.3.2.

5.3.3.3. definido.

5.3.3.4. Inquérito Erro! Indicador não definido.

5.3.4. Entrevista sobre o Habitat Familiar.

Análise da Genografia Projetiva Familiar ..... Erro! Indicador não definido.

5.3.4.1. Síntese da entrevista.... Erro! Indicador não definido.

5.3.4.2.

Análise da entrevista

Erro! Indicador não definido.

5.3.5. Espaciografia Projetiva Familiar. Erro! Indicador não definido.

5.3.5.1. Desenho da Casa dos Sonhos Erro! Indicador não definido.

5.3.5.2. Inquérito. Erro! Indicador não definido.

5.3.5.3. Codificação do desenho da casa dos sonhos.. Erro! Indicador não definido. Erro! Indicador não definido. 
5.4. Família de Marina Erro! Indicador não definido.

5.4.1. Apresentação. Erro! Indicador não definido.

5.4.2. Entrevista sobre a História Familiar e Hábitos AlimentaresErro! Indicador não definido.

5.4.2.1. Síntese da entrevista

Erro! Indicador não definido.

5.4.2.2. Análise da entrevista Erro! Indicador não definido.

5.4.3. Genografia Projetiva Familiar Erro! Indicador não definido.

5.4.3.1. Desenho da Árvore Genealógica. Erro! Indicador não definido.

5.4.3.2. Inquérito... Erro! Indicador não definido.

5.4.3.3. Codificação do desenho da árvore genealógicaErro! Indicador não definido.

5.4.3.4. Análise da Genografia Projetiva Familiar ..... Erro! Indicador não definido. 5.4.4. Entrevista sobre o Habitat Familiar. Erro! Indicador não definido.

5.4.4.1. Síntese da entrevista Erro! Indicador não definido.

5.4.4.2. Análise da entrevista Erro! Indicador não definido.

5.4.5. Espaciografia Projetiva Familiar. Erro! Indicador não definido.

5.4.5.1. Desenho da Casa dos Sonhos........................ Erro! Indicador não definido.

5.4.5.2. Inquérito.................................................. Erro! Indicador não definido.

5.4.5.3. Codificação do desenho da casa dos sonhos.. Erro! Indicador não definido.

5.4.5.4. Análise da Espaciografia Projetiva Familiar . Erro! Indicador não definido.

5.4.6. Síntese da família de Marina ........................... Erro! Indicador não definido.

6. DISCUSSÃO.............................................. ERRO! INDICADOR NÃO DEFINIDO.

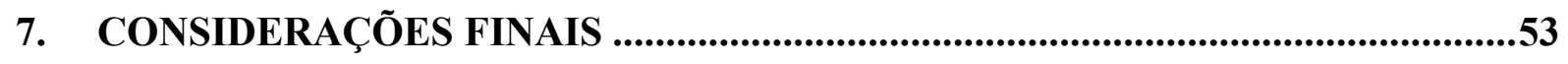

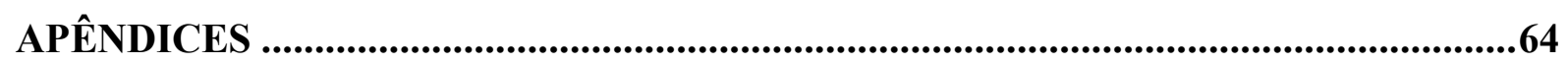

ANEXOS 



\section{APRESENTAÇÃO}

Este projeto faz parte de uma pesquisa mais ampla intitulada "O adolescente obeso face à sua família: pesquisa intercultural", fruto de uma parceria entre o Programa de Pósgraduação em Psicologia da Faculdade de Filosofia, Ciências e Letras de Ribeirão Preto da Universidade de São Paulo, a Universidade do Franche-Comté de Besançon, França, e a Universidade de Istambul, Turquia. O estudo tem como pesquisadoras responsáveis a Prof. ${ }^{a}$

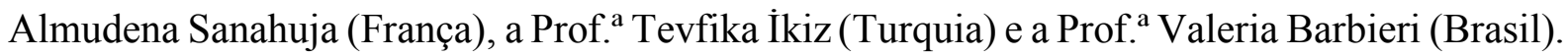
O objetivo central do projeto intercultural é analisar a dinâmica psíquica e a imagem inconsciente do corpo familiar e individual em famílias francesas, turcas e brasileiras em que ao menos um de seus membros (um adolescente) é obeso. Desta forma, procura-se apresentar novas pistas para um trabalho terapêutico direcionado ao adolescente e sua família, nos casos em que houver sofrimento emocional. Inicialmente, a pesquisa maior fará um contraste entre as famílias de adolescentes obesos e não-obesos dentro de cada um dos três países (França, Turquia e Brasil). Para o presente projeto de mestrado, o recorte realizado envolve o estudo de grupos familiares brasileiros nos quais um adolescente apresenta obesidade. A comparação entre todas as famílias participantes do estudo, francesas, turcas e brasileiras, será realizada pela equipe de pesquisa do projeto intercultural numa etapa posterior. 


\section{INTRODUÇÃO}

\subsection{Obesidade: prevalência e etiologia}

A obesidade é definida pela Organização Mundial de Saúde (OMS) como uma patologia crônica caracterizada por um acúmulo excessivo de tecido adiposo no organismo, que pode oferecer riscos à saúde do indivíduo (World Health Organization, 2018). A referência mais utilizada para a sua mensuração é o IMC, Índice de Massa Corporal, calculado pelo peso em quilogramas dividido pelo quadrado da altura em metros. Por meio desta medida, considerase em sobrepeso o indivíduo que possuir um IMC igual ou superior a $25 \mathrm{~kg} / \mathrm{m}^{2}$. Já a obesidade é dividida em três níveis: o grau I, que compreende IMC entre 30 e $34,9 \mathrm{~kg} / \mathrm{m}^{2}$; o grau II, para um IMC entre 35 e 39,9 kg/m²; e o grau III (obesidade mórbida ou severa), que se refere a um IMC acima de $40 \mathrm{~kg} / \mathrm{m}^{2}$ (World Health Organization, 2018).

Não existe ainda uma definição única de obesidade para a população infantil e jovem (Latzer \& Stein, 2013). O critério utilizado atualmente se fundamenta na análise de percentis proposta pelo Centro de Controle e Prevenção de Doenças dos Estados Unidos (CDC). De acordo com os dados dos Gráficos de Crescimento do CDC para a mesma idade e sexo, para crianças e adolescentes dos 2 aos 19 anos de idade, o sobrepeso é definido por um IMC acima do percentil 85 e a obesidade por um IMC acima do percentil 95 (Centers for Disease Control and Prevention, 2018). A OMS classifica a obesidade por escores-z, situando os pontos de corte para sobrepeso e obesidade respectivamente acima dos percentis 85 e 97. Este critério foi adotado pelo Ministério da Saúde do Brasil desde 2009 para crianças e adolescentes, desde o lactente até os 19 anos de idade. As curvas em escores-z propostas pela OMS são utilizadas para o diagnóstico assim como para a avaliação da evolução do paciente durante o tratamento (Melo, 2009). Adotamos para este trabalho o critério proposto pela OMS, devido à sua utilização pelo projeto intercultural anteriormente mencionado, do qual a presente pesquisa faz parte.

Nas últimas décadas, os índices de obesidade no mundo todo têm aumentado de forma preocupante. Pesquisas indicam que esta patologia configura hoje uma epidemia global (Camargo, Barros Filho, Antonio \& Giglio, 2013; Fisberg, Maximino, Kain \& Kovalskys, 2016), pois abrange todas as faixas etárias e níveis socioeconômicos, e atinge países desenvolvidos assim como aqueles em desenvolvimento. Segundo índices da OMS, em 2016 havia no mundo por volta de 1,9 bilhão de adultos de mais de 18 anos de idade com sobrepeso, dentre os quais 650 milhões eram obesos (World Health Organization, 2018). 
No Brasil, o excesso de peso e a obesidade são encontrados com frequência em todos os grupos de renda e regiões do país. Em 2014, atingiam quase 60\% da população (Instituto Brasileiro de Geografia e Estatística, 2014). Uma publicação recente do Ministério da Saúde apoiada pelos dados da Pesquisa de Vigilância de Fatores de Risco e Proteção para Doenças Crônicas por Inquérito Telefônico (Vigitel) mostrou que a obesidade no Brasil chegou a um nível recorde em 2018, atingindo $19,8 \%$ da população, o que significa um aumento de $67,8 \%$ neste índice desde 2006. O sobrepeso também teve seu índice aumentado no país, atingindo hoje 55,7\% dos brasileiros (Ministério da Saúde, 2019).

Caballero e Popkin (2002) assinalam que os avanços tecnológicos na produção de alimentos possibilitaram uma atenuação da fome generalizada e uma redução dos quadros de desnutrição; no entanto, a urbanização e a globalização, com a expansão dos meios de comunicação de massa e o marketing têm incentivado o consumo de alimentos industrializados ultraprocessados, excessivamente calóricos e de baixo valor nutritivo. A introdução cada vez maior desse tipo de alimento em diversos países e sua produção em larga escala, que minimiza seus preços, faz com que o consumo dos alimentos in natura, mais saudáveis e benéficos ao organismo, diminua progressivamente.

Além disso, os hábitos de vida da população mundial têm se transformado marcadamente ao longo das últimas décadas, tornando-se mais predominantes as atividades sedentárias (Xavier, Bielemann, Maciel, Neutzling \& Gigante, 2014). Todos esses fatores contribuem para a diminuição dos quadros de desnutrição e o aumento expressivo da prevalência de sobrepeso e obesidade ao redor do mundo, caracterizando a chamada transição nutricional, fenômeno que ocorre atualmente em vários países devido ao excesso e inadequação do consumo alimentar (Camargo et al., 2013).

Diversas comorbidades são associadas ao sobrepeso e à obesidade, como diabetes tipo 2, hipertensão arterial, doenças cardiovasculares e osteoartrite, que prejudicam a qualidade de vida do indivíduo e oferecem riscos à sua saúde (Pulgarón, 2013). De um ponto de vista psicológico, a obesidade não é considerada uma psicopatologia, já que não implica necessariamente a experiência do conflito psíquico. Entretanto, ela pode promover dificuldades psicológicas e psicossociais, como o isolamento, a insegurança, baixa autoestima, depressão e perturbações na imagem corporal (Luiz, Gorayeb \& Liberatore Júnior, 2010).

A obesidade se insere numa trama etiológica multifatorial, que abrange aspectos hereditários, fisiológicos, socioeconômicos, familiares, culturais e psicológicos (Fisberg et al., 2016; Oliveira \& Almeida, 2013). Esses aspectos têm sido estudados pela literatura, em maior 
ou menor grau, como precipitantes ou perpetuadores desta patologia, e percebe-se uma grande dificuldade para estabelecer o que seria efetivamente um disparador da obesidade e o que se constitui em uma consequência dessa condição. A busca por determinações mostra-se menos produtiva que o estudo mais compreensivo desta patologia, que se apresenta de maneira complexa e intricada para os pesquisadores, profissionais e serviços de saúde. O acúmulo de peso sinaliza um encontro de diversas conjunturas que, associadas, geram esse quadro multifacetado.

\subsection{Obesidade na infância e na adolescência}

A obesidade da criança e do adolescente é um problema crescente de saúde pública brasileira e mundial. Atinge cerca de 340 milhões de indivíduos entre 5 e 19 anos no mundo, sendo considerada pela OMS como um dos maiores desafios para a saúde pública do nosso século (World Health Organization, 2018). De acordo com Abarca-Gómez et. al. (2017), o número total no mundo de crianças e adolescentes obesos com idade entre 5 e 19 anos aumentou mais de dez vezes entre os anos de 1975 a 2016, passando de 11 milhões em 1975 para 124 milhões em 2016. No Brasil, pesquisas epidemiológicas constataram uma prevalência de excesso de peso em crianças e adolescentes entre 10,8 e 33,8\% em diferentes regiões (Tassara, Norton \& Marques, 2010).

Estudos revelam que o excesso de peso na infância aumenta as chances de obesidade na idade adulta, e constitui um fator de risco para diversas comorbidades, como hipertensão arterial, resistência à insulina e doenças cardiovasculares (Starc \& Strel, 2010; Tenorio \& Cobayashi, 2011). Embora fatores genéticos predisponham o desenvolvimento da obesidade, destacam-se hoje como grandes agravantes dessa patologia na faixa etária pediátrica os fatores ambientais e comportamentais, como a falta de atividade física e o aumento do consumo de alimentos mais calóricos (Tenorio \& Cobayashi, 2011). Camargo et al. (2013) apresentam também como fatores relevantes o abandono precoce do aleitamento materno, a utilização frequente de alimentos formulados e processados, assim como o interesse pelos jogos eletrônicos e pela televisão em detrimento de atividades como andar de bicicleta e brincar na rua.

Moraes e Dias (2013) afirmam que a obesidade acarreta diversos prejuízos à vida social da criança e do adolescente, dificultando seus relacionamentos e seu desempenho em atividades em grupo. Além disso, é uma doença à qual não se atribui a mesma dignidade das outras, sendo que nem sempre é levada a sério e pode até mesmo ser tratada como cômica. Os jovens obesos 
são frequentemente discriminados e maltratados pelos colegas e são menos aceitos do que aqueles de peso normal. Isto pode ter um impacto negativo em sua qualidade de vida e prejudicar seu desenvolvimento psíquico e físico, criando um ciclo vicioso que reforça os comportamentos agravantes da obesidade, já que esses jovens tendem a tornar-se mais reclusos ou a evitar as atividades que exponham seu corpo e suas habilidades físicas, como o esporte (Lemes, 2004).

A hostilidade social à obesidade tem crescido muito. A sociedade capitalista, ao incitar o consumo sem limites, dá margem à compulsão e às patologias que sobrevêm deste cenário de excessos; no entanto, estigmatiza e exclui o indivíduo obeso. O corpo e a estética têm hoje uma importância que ultrapassa o cuidado com a saúde, para associar-se a um culto à aparência e ao estabelecimento de padrões opressores de beleza. Novaes (2009) afirma que nosso corpo tem se transformado num objeto de regulação social, e a busca pelo ideal de perfeição física tem trazido grande sofrimento, tornando a relação com o próprio corpo persecutória e desprazerosa. A autora destaca ainda que a imagem negativa da obesidade no imaginário social leva à dificuldade de manutenção do peso normal a ser vista como consequência de preguiça e falta de esforço. Assim, a obesidade não é socialmente entendida como uma patologia, mas como um desleixo que traduziria uma inadequação do relacionamento do indivíduo com seu próprio corpo.

No caso dos adolescentes obesos, as dificuldades se intensificam. O pertencimento é uma questão central para o adolescente, portanto a estigmatização é vivida com intenso sofrimento. Como afirma Ungar (2015), a adolescência é uma etapa da vida que se constitui "num paradigma do entrelaçamento do corporal com o psíquico e com o social" (p. 1). Assim, é fundamental considerar tanto o mundo interno do adolescente quanto sua provisão ambiental e seu momento histórico, social e político, para compreender esta etapa de sua vida. Ungar considera os adolescentes como o grupo que enfrenta os maiores desafios das transformações da sociedade, pois eles as absorvem muito rapidamente e se apropriam dessas mudanças de maneira poderosa. A fixação no corpo e, mais especificamente, em sua aparência externa, é muito instigada pelos veículos de comunicação e tem tido um impacto visível nos adolescentes, que chegam aos consultórios médicos e aos serviços de Psicologia com queixas frequentes relacionadas à alimentação e à imagem corporal. 


\subsection{A família e a obesidade do adolescente}

A obesidade da criança e do adolescente tem sido relacionada às primeiras relações interpessoais do sujeito, ou seja, à relação com seus familiares e, principalmente, com os primeiros cuidadores (Campana, Gomes \& Lerner, 2014). A literatura destaca que dificuldades no vínculo mãe-filho são um elemento eliciador e perpetuador de quadros de obesidade infantil (Mishima-Gomes, Dezan \& Barbieri, 2014). McDougall (1984) afirma que, em face da falta de uma mãe introjetada que cuida e alimenta emocionalmente, o indivíduo obeso busca no mundo externo um substituto não simbolizado, o alimento concreto. Todo afeto ameaçador é, então, descarregado no comportamento alimentar e esta busca se torna compulsiva, já que a falta nunca é reparada.

Mishima e Barbieri (2009) buscaram compreender os psicodinamismos de crianças obesas, ressaltando a ligação emocional entre mães e filhos. Os resultados apontaram para uma experiência de deficiência no holding exercido pelas mães durante o estágio de dependência (Winnicott, 1964/1982), levando ao prejuízo dos filhos na capacidade de simbolização e na expressão da criatividade, assim como a seu apego ao objeto concreto, neste caso o alimento. Miranda (2010) também sugere haver uma relação entre o comer compulsivo e as relações primitivas, indicando que o primeiro pode ser sentido, na obesidade, como um equivalente ao ato de restaurar o bom objeto, uma busca pelo preenchimento da nutrição materna com leite e amor.

A adolescência é um momento crucial para a subjetivação do indivíduo, permeada por remodelamentos e ressignificações corporais, psíquicas e sociais. Jordão (2008) descreve que, enquanto o adolescente passa por uma turbulenta revisão de seus objetos internos, reeditando sentimentos e vínculos primários, seus pais também sofrem com esse processo angustiante e confuso, deparando-se com questões relativas à separação, diferenciação e finitude. $\mathrm{O}$ adolescer de um filho opera, assim, uma alteração marcante da dinâmica familiar, causando frustrações e feridas narcísicas em todos os membros da família. No entanto, esse processo é imprescindível para a construção da subjetividade do adolescente, rumo à sua vida adulta independente.

O lugar que um filho ocupa na fantasmática individual de cada um de seus pais é determinado pelo sistema narcísico parental: a criança, ao nascer, torna-se o representante primário do desejo inconsciente da mãe e do pai (Jordão, 2008). Por isso, há frequentemente uma dupla resistência ao crescimento do filho, por parte dos pais e do próprio adolescente, que deve atuar o desligamento de suas identificações primárias. Novaes (2009) descreve que, para o adolescente, abandonar o corpo do "bebê gorducho" e incorporar as mudanças fisiológicas da 
adolescência, construindo novos processos de escolha e pertencimento, implica abdicar do lugar de objeto narcísico do desejo parental, para buscar novos modelos identificatórios. Esse remanejamento das identificações leva a uma nova apropriação pelo adolescente dos projetos infantis, ou seja, a uma diferenciação progressiva em relação aos sonhos neles projetados pelos pais. Muitas vezes, contudo, o que acontece em algumas famílias é a negação dessa separação e a tentativa de suprimi-la, visando manter o equilíbrio narcísico da família.

Tassara et al. (2010) relatam que a vivência das mães de seus próprios sofrimentos aprisionados pode ser reeditada na relação com os filhos, traduzindo-se em dependência e superproteção e, no caso da obesidade, na preocupação excessiva com a alimentação. Esse modelo de relação mãe-filho, caracterizado pela indiferenciação, contribui para um distanciamento eventual da figura paterna e para uma restrição do movimento ativo e das iniciativas próprias da criança. Mishima-Gomes et al. (2014) também ressaltam a importância da figura paterna no funcionamento psíquico de crianças obesas, indicando que a dificuldade no exercício suficientemente bom da paternidade influenciaria negativamente a maneira como os filhos se relacionam com o mundo compartilhado e os objetos externos.

A dificuldade relativa à diferenciação psíquica entre os membros da família é destacada como um elemento presente nos casos de obesidade do adolescente. Akay, Ozturk, Avcil, Kavurma e Tufan (2015) ressaltam que famílias de jovens obesos mostraram complicações no vínculo afetivo, podendo apresentar um alto grau de envolvimento e indiferenciação entre os membros, ou então um distanciamento pronunciado. Os autores concluíram que o envolvimento insuficiente pode levar os jovens a padrões desordenados de alimentação, enquanto o excesso de envolvimento e a parentalidade intrusiva conduziriam à alimentação excessiva como um mecanismo de regulação emocional; além disso, a alimentação desregrada e descomedida poderia também funcionar como uma tentativa do jovem de estabelecer alguma autonomia frente ao contexto emocional invasivo.

Novaes (2009) destaca que algumas famílias vivem um estado emocional de fusão, em que suas mentes não se encontram individualizadas. Sua história é vivida como uma sucessão linear de eventos experimentados da mesma maneira por todos os indivíduos, negando a heterogeneidade e a diferenciação entre os membros. Vivem uma isomorfia, uma igualdade entre o aparelho psíquico familiar e os diferentes aparelhos psíquicos individuais. Novaes afirma que esta situação pode ser encontrada em famílias de jovens obesos. Neste contexto, a obesidade favorece o desejo inconsciente do adolescente de manter um corpo gordo e infantil, afastando-se do processo de crescimento e de desenvolvimento da sexualidade para não perder 
os pais idealizados da infância. A preocupação da família com o peso e a dieta do jovem, em algumas situações, pode evidenciar para ele seu fracasso em emagrecer, sendo traduzida em seu reverso como resistência a um processo de independência do filho, num imperativo categórico de que nenhuma diferenciação possa existir.

Sanahuja e Cuynet (2011) afirmam que, na adolescência, o legado de todas as identificações individuais e familiares é revisitado, desafiando as bases identitárias do sujeito. Segundo esses autores, a hiperfagia seria uma conduta aditiva que busca controlar uma situação generalizada de mal-estar, em que somente o corpo ajuda a conter a realidade. Uma falta infinita que se sente da presença do outro, mais especificamente da presença do amor do outro, busca ser suprimida pela onipresença da satisfação concreta do corpo, neste caso, por meio do alimento. O vício do sujeito obeso por uma reiteração da experiência corpórea de plenitude responde a demandas impensáveis de preenchimento emocional e afetivo, fruto de um vazio existencial que ele carrega consigo.

A dificuldade de diferenciação do jovem obeso em relação à sua família é ressaltada também em outro estudo de Sanahuja, Schwailbold e Cuynet (2014). Segundo eles, a dependência dos adolescentes obesos em relação aos pais mostra-se forte e a separação identitária, especialmente em relação à mãe, é bastante difícil. Do ponto de vista psicodinâmico, a pesquisa afirma que a obesidade de um indivíduo revela conflitos intrapsíquicos e intersubjetivos, constituindo-se como sintoma transgeracional que denuncia problemas de continência no grupo familiar. Desta forma, o auxílio no processo de diferenciação do jovem em relação aos seus pais pode funcionar como uma base terapêutica no tratamento da obesidade no adolescente.

Ramalho, Lachal, Bucher-Maluschke, Moro e Revah-Levy (2016) assinalam que a obesidade do adolescente não somente aponta para uma dependência do jovem em relação à família, mas pode também intensificá-la, por meio dos conflitos relacionados com o controle da comida e das decisões sobre o que o jovem pode ou não comer. Os autores também consideram, portanto, que as inter-relações entre a dinâmica alimentar e a dinâmica familiar devem ser analisadas no desenvolvimento de estratégias terapêuticas para os adolescentes obesos. Eles ressaltam que a alimentação, em seu sentido mais primário, que remete à amamentação, constitui um ato de amor e cuidado dos pais para com seus filhos. É um processo que implica uma dupla dependência: os pais provam seu amor aos filhos pela alimentação, e os filhos provam seu amor aos pais ao aceitar seu alimento. Numa relação familiar que busca manter essa dependência, a comida pode ser usada para expressar aspectos primitivos desse 
relacionamento, assim como uma necessidade de permanência da família nessa modalidade de relação. A recusa do jovem em cuidar de sua própria alimentação sem a necessidade de regulação e supervisão seria uma forma de assegurar sua dependência em relação aos pais, de forma que existe uma ambivalência afetiva no adolescente obeso: por um lado, ele deseja construir sua autonomia, mas reforça ao mesmo tempo o controle parental pela outorga da gestão de seu comportamento alimentar. A manutenção de uma alimentação desajustada pelo adolescente mantém, então, os pais presentes neste papel de reguladores.

De acordo com Vilhena (1991), o grupo familiar costuma perceber-se como uma unidade psíquica, que não se constituiria apenas como um conjunto dos aparelhos psíquicos individuais de cada um de seus membros, mas como uma psique singular totalizadora, por meio de uma ilusão de fusão numa psique originária. Esta se torna sede dos núcleos simbióticos de cada indivíduo que a integra. Cria-se, deste modo, um "nós" psíquico, nome dado por Vilhena a uma dinâmica que perpetua a parceria e o sentimento de igualdade na identidade do grupo familiar. A obesidade pode funcionar, neste cenário, como um traço identificatório entre os membros da família e como uma forma de preservação dos papéis originários de cada indivíduo no grupo familiar.

O filho obeso, deste modo, seria mantido em seu lugar infantil, devendo para sempre ser responsável por atender ao narcisismo parental. Ao identificar-se com os sonhos (e com os pesadelos) dos pais, o adolescente não pode criar sua própria subjetividade; por outro lado, garante seu lugar inalterado na dinâmica familiar, escapando ao temor da perda do amor dos pais. Todo adolescente tem grandes desafios a superar junto à sua família: uma aproximação íntima em relação ao seu corpo, que será ressignificado; a apropriação de sua história, do passado de sua família; e o afastamento do projeto idealizado pelos pais, para assumir a direção da sua própria vida segundo seus desejos (Jordão, 2008). Já o adolescente obeso, além de todos esses desafios, terá que empreender um movimento em direção à construção de uma subjetividade própria e de um desejo próprio. Para poder afastar-se dos projetos idealizados da família, terá que fabricar um lugar para si mesmo em seu próprio mundo interno, que dê sentido à sua existência fora do desejo parental e da dinâmica psíquica familiar.

\subsection{A intersubjetividade na constituição do psiquismo}

\subsection{Terceiridade e o trabalho do negativo}

\subsection{Alianças inconscientes}

\subsection{Transmissão psíquica geracional}

\subsection{Imagem inconsciente do corpo familiar e obesidade do adolescente}


A utilização de dois instrumentos projetivos grupais, a Genografia Projetiva Familiar (Cuynet, 2015) e a Espaciografia Projetiva Familiar (Cuynet, 2017), tem como propósito realizar um diagnóstico grupal acerca da construção do aparelho psíquico da família, a fim de investigar a sustentação da obesidade como sintoma da constituição psíquica familiar. 


\section{JUSTIFICATIVA}

Pesquisas apontam a importância das relações do sujeito com seus familiares e especialmente com os primeiros cuidadores para a compreensão dos aspectos emocionais do quadro de obesidade infantil e do adolescente. Famílias de jovens obesos têm demonstrado dificuldades nos vínculos afetivos relativas à indiferenciação entre os membros, estados emocionais de fusão e dependência do adolescente em relação aos pais. A literatura relata uma concentração dessa problemática especialmente na relação entre mães e filhos, assim como a existência de um distanciamento ou enfraquecimento das figuras paternas, fatores que têm se demonstrado como eliciadores e perpetuadores dos quadros de obesidade na infância e na adolescência.

A presente investigação se insere nesse contexto, buscando um aprofundamento da compreensão acerca dos motivos da instalação e da manutenção dessas dinâmicas na família. As contribuições da psicanálise contemporânea acerca do início da vida do bebê e dos relacionamentos com seus objetos primordiais, assim como o arcabouço teórico-clínico desenvolvido pela psicanálise vincular, que investiga as formas de transmissão de conteúdos psíquicos entre gerações, enriquecem as possibilidades investigativas acerca dos relacionamentos familiares e são norteadoras desta pesquisa.

Durante a adolescência, o indivíduo passa por um processo de revisão de seus objetos internos e por uma reedição de seus vínculos primários, de forma que seus pais e sua família também sofrem com as mudanças neste período. Trata-se de uma oportunidade para a revisão de conflitos e das dinâmicas entre os membros da família, assim como um momento difícil que leva o grupo familiar a reviver angústias antigas, fazendo com que se depare com um imperativo de transformações em seu tempo presente. Assim, justifica-se a escolha por estudar famílias de adolescentes com um quadro de obesidade. 


\section{OBJETIVOS}

\subsection{Objetivo geral}

A presente pesquisa almeja conhecer a dinâmica psíquica familiar de adolescentes com obesidade e suas famílias, por meio de dois instrumentos projetivos de avaliação psicológica familiar, a Espaciografia Projetiva (Cuynet, 1999) e a Genografia Projetiva (Cuynet, 1998), assim como utilizando-se de entrevistas semiestruturadas direcionadas ao grupo familiar. Por dinâmica psíquica familiar, entende-se a natureza das relações intersubjetivas, dos conteúdos psíquicos transmitidos e compartilhados na família, como são vividos os processos de subjetivação e a relação com o meio externo, assim como o lugar assumido pelo jovem e por cada um dos membros dentro do grupo familiar.

\subsection{Objetivos específicos}

a) Conhecer a dinâmica psíquica grupal de famílias de adolescentes com o diagnóstico de obesidade, com o propósito de investigar se existiriam associações entre essa patologia no jovem e suas relações intersubjetivas familiares;

b) Compreender as relações intersubjetivas nessas famílias, a constituição de seu envelope psíquico grupal e de seu corpo psíquico familiar, observar os lugares assumidos no grupo pelo adolescente e seus familiares, assim como analisar o compartilhamento e a transmissão de elementos psíquicos entre membros e gerações das famílias;

c) Aprofundar a compreensão dos aspectos psíquicos familiares nos quadros de obesidade no adolescente para auxiliar no norteamento de intervenções terapêuticas direcionadas ao adolescente com obesidade e sua família. 


\section{MÉTODO}

\subsection{Método qualitativo}

A presente pesquisa foi desenvolvida a partir da perspectiva clínico-qualitativa de investigação científica. A abordagem qualitativa permite uma compreensão abrangente de fenômenos complexos de natureza social, não passíveis de quantificação (Turato, 2003; Vieira Filho \& Teixeira, 2003), e auxilia no entendimento das relações entre o que se manifesta concretamente e aquilo que não é visível ao olhar comum. Nesse enfoque, que se distancia de um enquadramento matemático dos dados, o pesquisador é o instrumento principal da coleta e do registro de fenômenos, utilizando para isso sua percepção e seus sentidos. Ele significa seu objeto de estudo de maneira compreensiva e interpretativa, oferece escuta e acolhimento às angústias dos participantes da pesquisa e valoriza os aspectos psicodinâmicos mobilizados na relação entre pesquisador e participantes (Turato, 2005). O envolvimento afetivo que ocorre nessa relação é o que possibilita elucidar subentendidos que podem surgir na investigação (Vieira Filho \& Teixeira, 2003).

O foco da pesquisa não recai sobre seu produto final, mas na compreensão do sujeito ou do objeto de estudo (Turato, 2005). Assim, na pesquisa qualitativa não se estabelecem hipóteses prévias acerca dos resultados, sob risco de enrijecimento e parcialidade, e as escolhas feitas inicialmente pelo pesquisador não são decisivas, já que o processo prevê o questionamento constante e a necessidade de reformulações. O pesquisador se coloca, portanto, em unidade com o processo investigativo e a construção do conhecimento, de forma que sua análise dos dados ocorre de forma concomitante à coleta (Barbieri, 2008). Por ressaltar os significados atribuídos aos fenômenos pelo pesquisador, que integra deste modo as informações obtidas, a subjetividade e o simbolismo são definidores dessa abordagem (Minayo, 2012).

Turato (2005) particulariza como um vértice da pesquisa qualitativa o que denomina método clínico-qualitativo, o qual busca compreender os fenômenos psicológicos relacionados às vivências de saúde e doença em seus diferentes ambientes, considerando o meio sociocultural no qual estão inseridos paciente, família e profissionais de saúde. Essa vertente considera todo ser humano como portador de sofrimentos existenciais que devem ser captados pelo pesquisador. Este se coloca numa posição empática, voltado ao sujeito de pesquisa com sua escuta e acolhimento, disposto a compartilhar de suas angústias. Movido pelo desejo de proporcionar ajuda, o investigador utiliza, por fim, seus conhecimentos sistematizados e recursos técnicos para elaborar um diagnóstico e uma análise profunda de seu objeto de estudo. 


\subsubsection{Pesquisa em psicanálise}

A psicanálise foi eleita como referencial teórico-metodológico deste estudo, por permitir ao pesquisador o acesso aos aspectos inconscientes dos fenômenos psíquicos (Aiello-Vaisberg \& Machado, 2004), o que torna possível uma exploração profunda das relações do indivíduo consigo mesmo e com o outro.

Silva e Macedo (2016) recordam as origens empíricas da pesquisa de Freud, que, antes da descoberta do inconsciente, teve sua formação iniciada nas ciências médicas. A aproximação freudiana em direção ao funcionamento da mente humana se fez, em princípio, por meio da investigação de sintomas, o que depois se desenvolveu num método de tratamento. Segundo afirma Conte (2004), o distanciamento de Freud de uma lógica causal e de uma visão consciencialista da compreensão dos fenômenos humanos levou à consolidação da psicanálise como uma nova forma de investigação. A descoberta do inconsciente como seu objeto de estudo, assim como a construção progressiva de um método específico para acessá-lo fizeram com que Freud se afastasse cada vez mais do positivismo científico que imperava em sua época.

Diferentemente das ciências médicas, a psicanálise não possui um objeto de estudo passível de delimitação: o inconsciente se manifesta por meio do discurso do indivíduo, sendo impossível acessá-lo diretamente. Para Birman (2003), a formulação de Freud do conceito de inconsciente subverteu os saberes da época sobre o psiquismo humano, a saber, a psicologia e a psiquiatria. Ele criou, assim, uma nova forma de fazer ciência, cujo rigor se encontra na coerência de sua teoria, de seu método e de sua técnica para com a premissa ética do inconsciente.

A teoria psicanalítica é indissociável de seu método e de sua técnica. A subjetividade do psicanalista está, portanto, intimamente implicada enquanto ele pesquisa, teoriza ou pratica a psicanálise. Conforme aponta Garcia-Roza (2009), as teorias científicas surgem não somente da observação de fatos, mas da busca de um pesquisador por conhecer determinado fenômeno. Assim, sua observação envolve necessariamente um lugar de partida, seu olhar subjetivo que traz consigo seus aportes teóricos e sua visão de mundo, o que possibilita a construção de novas inteligibilidades para o fenômeno pesquisado.

Ao discorrer sobre o método investigativo, Bunge (2018) propõe que, a partir de sua compreensão imperfeita do mundo, o ser humano tenta dominá-lo a fim de tornar sua existência nele mais confortável. Neste processo, constrói para si um mundo artificial, por meio de um crescente corpo de ideias a que chama ciência. Bunge afirma que o homem, ao procurar tornar este conhecimento científico racional, sistemático, exato e verificável, torna-o também falível. 
Em contraposição à ideia de neutralidade almejada pela ciência positivista, contudo, a psicanálise assume o olhar do pesquisador como intrínseco à sua observação, valorizando sua subjetividade como parte imprescindível da construção de conhecimento científico.

Figueiredo e Minerbo (2006) distinguem a pesquisa em psicanálise da pesquisa com o método psicanalítico. Segundo eles, a pesquisa em psicanálise é aquela que utiliza o saber psicanalítico como instrumento teórico, e pode, desta maneira, ser feita por qualquer pesquisador interessado, seja ele um psicanalista, um filósofo ou um historiador. Já a pesquisa em psicanálise com o método psicanalítico requer necessariamente a presença do psicanalista, e não admite uma distância objetiva entre pesquisador, referencial teórico e objeto pesquisado; funciona como uma relação corpo-a-corpo a partir da qual o pesquisador, seu objeto de estudo e a própria psicanálise saem transformados.

Sendo assim, não há espaço neste tipo de pesquisa para uma objetividade que busca apenas verificar ou refutar hipóteses pré-estabelecidas. O pesquisador, na relação com seu objeto de estudo, entrega-se a ele e se deixa fazer por ele, ao mesmo tempo em que continuamente constrói e transforma o próprio objeto pesquisado. Este tipo de pesquisa funciona como um "momento na história de uma relação que não deixa nenhum dos termos tal como era, antes de a própria pesquisa ser iniciada" (Figueiredo \& Minerbo, 2006, p. 260). Este momento captado pela pesquisa é, portanto, irrepetível e singular, o que evidencia ao mesmo tempo os limites e a utilidade dos conhecimentos que podem ser produzidos a partir dela. A busca por confirmações de hipóteses estruturadas, neste contexto, torna estéril o campo relacional entre pesquisador e objeto, cujo potencial é a desconstrução do que foi pré-concebido e criação de novas possibilidades de pensamento.

A procura por certezas acompanha a história dos seres humanos, enquanto membros de uma sociedade e de uma cultura, e enquanto indivíduos. Desde o desenvolvimento da própria ciência até aquele de cada indivíduo, há um movimento constante de busca por verdades e, ao mesmo tempo, de edificação de obstáculos a fim de falsificá-las. Desde que nascemos, somos pesquisadores: observamos o mundo que nos integra e o modificamos a todo momento, sendo também transformados por este contato. Sendo todos pesquisadores, sofremos do mesmo desejo por conhecimento, e também das mesmas quimeras - nossas convicções que muitas vezes nos aprisionam e obstruem o caminho frutífero dos questionamentos.

Bion (1970/1991) trouxe à teoria psicanalítica uma discussão imprescindível acerca da importância do pensamento e, com isso, levou o próprio psicanalista a refletir sobre seu papel na construção - ou obstrução - do conhecimento, assim como na busca pelas verdades ou na 
fabricação de armadilhas para falsificá-las. Ele introduziu na psicanálise o conceito de capacidade negativa, termo que emprestou do poeta Keats e que utiliza para descrever uma possibilidade de existir em meio aos mistérios, às dúvidas e incertezas, sem apressar uma formação de significados e sem fazer esforço para conquistar fatos e razão (Bion, 1970/1991). A partir de um mergulho profundo na atividade do pensamento, Bion propõe uma reflexão sobre a dificuldade humana de conviver com o desconhecido, de suportar o não saber, e os problemas que isso acarreta para a produção de conhecimento. Bion (1957/2013) descreve este processo na situação de análise, a qual, considera como sendo, ela própria, uma manifestação de curiosidade. Analista e paciente se encontram num movimento de busca pela verdade, portanto estão ambos sujeitos às suas falsificações, que podem ser construídas por um, por outro ou pela dupla assim que conteúdos novos ameaçam surgir.

Zimerman (2010) afirma que as formulações de Bion proporcionaram grandes inovações à prática psicanalítica cotidiana, a qual passou a fugir do "princípio da certeza" e enaltecer o “princípio da incerteza” (Zimerman, 2010, p. 147). Neste novo modo de fazer e pensar a psicanálise, o analista não se julga detentor da verdade sobre o seu paciente, considerando a verdade algo sempre relativo e variável. A psicanálise clássica propõe ao paciente a livre associação de ideias, à qual se segue a interpretação pelo analista dos conflitos internos contidos neste material expresso pelo paciente. Conforme afirma Zimerman, Bion sugere que uma interpretação pode ser "certa" em termos de forma, conteúdo e de adequação quanto ao momento em que foi formulada para o paciente; mas isso não significa necessariamente que ela será eficaz. Ou seja, interpretações "corretas” podem ser inócuas e não levar a transformação alguma do paciente. É necessário que o analista se preocupe, portanto, não com a exatidão de suas interpretações, mas com o destino que elas tomam no psiquismo do paciente: ele pode ouvi-la e refletir sobre ela, mas pode também esterilizá-la, esvaziá-la, ou mesmo negá-la totalmente. $\mathrm{O}$ paciente pode concordar com as interpretações, criando um clima de aceitação entre ele e seu analista em que ambos se sentem satisfeitos, e não apresentar mudanças substanciais no tratamento. Isso pode acontecer quando o paciente não deseja realmente tomar conhecimento de si.

Como descreve Zimmer (2013), nos momentos em que novos conteúdos inconscientes começam a emergir na situação analítica, há uma tensão inevitável entre o desejo de compreender melhor e o medo do que ainda não é compreendido. Para evitar o contato com um conteúdo completamente desconhecido, o indivíduo pode se recolher num estado de autossatisfação arrogante, restringindo-se a uma relação interna com aquilo que já é conhecido 
e tratando o que não conhece com condescendência. Nestes momentos, a dupla analítica deve buscar restabelecer uma sensação de curiosidade compartilhada em seu trabalho, assim como uma tolerância para suportar aquela experiência que já pode ser vista ou sentida, mas que ainda não é compreendida.

A capacidade da dupla analítica para receber esses conteúdos desconhecidos ao invés de evitá-los é crucial para o desenrolar do processo analítico. A curiosidade compartilhada que impulsiona a exploração na situação analítica é um estado inerentemente doloroso, no qual o não saber deve ser continuamente tolerado (Zimmer, 2013, p. 408). Desta forma, a curiosidade pode ser facilmente subvertida e transformada num dispositivo para uma afirmação de onisciência de um indivíduo, em conjunto com da projeção de todo o não saber e da incompreensão no outro. Daí a busca de confirmação de hipóteses: o indivíduo busca conformar a realidade observada ao que ele já sabe; e levanta questionamentos cujas respostas ele acredita já conhecer.

Estes movimentos que ocorrem na situação analítica podem ser extrapolados para qualquer atividade de busca por conhecimento. Paciente e analista, grupos de pesquisa ou mesmo a comunidade científica como um todo podem sofrer da criação de ilusões, em que se mantém uma impressão de produtividade e busca por novos conhecimentos, enquanto se realiza de fato um ritual reconfortante que serve para manter uma sensação de onisciência, seja individual, seja compartilhada (Zimmer, 2013, p. 394).

Seja na situação analítica, no desenvolvimento psíquico de um indivíduo ou na pesquisa científica, a construção de conhecimento e a busca pela verdade encontram diversos obstáculos produzidos pelos próprios seres humanos, pesquisadores ou conhecedores em potencial. São armadilhas que funcionam como ataques ao próprio conhecimento a fim de livrar a mente do que lhe é muitas vezes insuportável: a angústia de estar em meio ao desconhecido. A busca por convicções, que se manifesta muitas vezes na pesquisa científica pela necessidade de mensuração, de confirmação e refutação de hipóteses pré-estabelecidas, pode revelar um movimento contrário à busca pelo conhecimento: ela pode sinalizar um engessamento da nossa capacidade de crescimento mental, que tem como motor o acesso ao novo por meio da tolerância do não saber.

A psicanálise tem muito a contribuir com a ciência contemporânea. Primeiramente, por oferecer um conjunto extenso e coerente de descobertas acerca do funcionamento mental humano, construído a partir de um contato constante com a realidade cotidiana de seus psicanalistas e pesquisadores. Mas, principalmente, porque possui recursos internos à sua 
própria teoria e ao seu método que permitem revelar as muitas armadilhas que surgem em seu caminho rumo ao conhecimento. Tais recursos potencializam a habilidade inovadora da psicanálise, afirmando-a como um competente método científico de investigação, tratamento e compreensão do ser humano.

\subsubsection{Estratégia metodológica}

A estratégia metodológica utilizada nesta pesquisa é o estudo de caso, condizente com a abordagem psicanalítica, pois permite uma descrição da complexidade e da particularidade dos fenômenos a serem estudados, de modo que sejam enxergados em suas múltiplas dimensões, e sempre implicados de forma intrínseca ao seu contexto. Esse método propicia ao investigador uma pluralidade de variáveis de interesse e fontes de evidência, enriquecendo ao mesmo tempo a pesquisa e o pesquisador (Yin, 2015).

\subsubsection{Técnicas projetivas na pesquisa psicanalítica}

Em consonância com o projeto maior em que a presente pesquisa está inserida, são utilizadas duas técnicas projetivas para a realização de um diagnóstico familiar. A utilização de instrumentos projetivos para a avaliação da personalidade contribui para uma apreensão profunda e compreensiva do sujeito em conjunto com o referencial teórico-metodológico da psicanálise, já que são técnicas fundamentadas na associação livre, que permitem o acesso aos conteúdos inconscientes dos participantes (Aiello-Vaisberg, 1995). Os instrumentos pouco estruturados para coleta de dados favorecem a construção de sentido pelo próprio participante a partir de seus referenciais pessoais e íntimos, devido à ambiguidade dos estímulos (Barbieri, 2008), o que estimula seu contato consigo próprio e a emergência de conteúdos inconscientes.

De acordo com Anzieu (1986), o caráter projetivo dessas técnicas provém de sua capacidade de trazer à superfície aquilo que se encontra latente na psique do indivíduo, da possibilidade de expulsão de conteúdos internos do sujeito e seu depósito sobre o material, assim como pela associação possível entre as respostas do indivíduo e sua estrutura de personalidade. A expressão desses conteúdos, normalmente dificultada por diversos mecanismos de defesa, é facilitada pelo aspecto indireto das técnicas, por não possuírem significado dado a priori ou formas corretas de execução, e por deixarem lacunas que envolvem o sujeito no processo e estimulam a projeção. 


\subsection{Participantes}

Participaram da amostra desta pesquisa quatro adolescentes com suas respectivas famílias, sendo dois deles do sexo feminino e dois do sexo masculino, sob os seguintes critérios de inclusão: ter idade entre 12 e 18 anos, diagnóstico de obesidade (IMC-por-idade localizado no percentil 97 ou acima, de acordo com os gráficos da OMS, 2009), nível socioeconômico médio ou baixo. Como família, considerou-se o grupo de pessoas que viviam sob o mesmo teto com o adolescente em questão, sendo que participaram da pesquisa apenas os membros que desejaram e puderam estar presentes durante a avaliação. As configurações familiares da amostra foram diversas: nuclear, monoparental e reconstituída.

Os critérios de exclusão utilizados foram: suspeita de patologias psiquiátricas graves do adolescente, adição, anorexia ou bulimia; déficit cognitivo profundo, dificuldades neurológicas, visuais ou verbais que comprometessem a aplicação dos instrumentos. Esses aspectos foram identificados no momento do primeiro contato, a partir do preenchimento das fichas de identificação empregadas na pesquisa, assim como no decorrer da avaliação familiar. Caso alguma família se inserisse nos critérios de exclusão, seria realizada uma entrevista devolutiva explicando as razões do não prosseguimento da coleta de dados. Não houve, no entanto, a necessidade de exclusão de nenhuma família.

No primeiro momento da coleta de dados, buscaram-se participantes que estivessem iniciando tratamento para obesidade no Ambulatório de Nutrologia da Secretaria Municipal de Saúde de Ribeirão Preto. Devido a uma escassez de casos encaminhados a partir desta primeira fonte, optou-se por uma divulgação da pesquisa em redes sociais e pela rede pessoal de contatos da pesquisadora, por meio de uma breve descrição dos objetivos da investigação e do perfil dos participantes buscados. Das quatro famílias participantes, uma delas foi encaminhada pelo Ambulatório de Nutrologia, e três foram recrutadas a partir da divulgação da pesquisa em redes sociais e pela rede pessoal de contatos da pesquisadora.

\subsection{Instrumentos}

Foram aplicadas em grupo, nos participantes desta pesquisa, duas entrevistas semidiretivas, a saber, a Entrevista Sobre a História Familiar e os Hábitos Alimentares e a Entrevista Sobre o Habitat Familiar (Anexos G e I, respectivamente), fornecidas pelos pesquisadores do projeto intercultural "O adolescente obeso face à sua família" e traduzidas do francês para o português pela pesquisadora. Além das entrevistas, foram aplicados dois instrumentos projetivos, a Genografia Projetiva Familiar e a Espaciografia Projetiva Familiar, 
concebidos por Patrice Cuynet $(2015$; 2017), ainda não padronizados para a população brasileira, assim como dois inquéritos, os quais se seguem à aplicação de cada uma das técnicas. Estas duas técnicas projetivas são complementares e permitem obter uma representação da dinâmica inconsciente do grupo familiar.

A Genografia Projetiva Familiar consiste no desenho livre de uma árvore genealógica por todos os membros da família em conjunto, em situação terapêutica ou de diagnóstico familiar. A aplicação da técnica é sempre precedida pela Entrevista Sobre a História Familiar e os Hábitos Alimentares, que introduz temas a serem evocados pela família para a construção de sua árvore genealógica. Busca-se com esta técnica obter uma representação da imagem inconsciente do corpo familiar, realizando uma topografia projetiva do mundo interno da família.

Cuynet e Mariage (2004) afirmam que os processos psíquicos projetivos envolvidos nessa ação têm um efeito regressivo, de forma que os organizadores inconscientes do grupo (como a ilusão, a fantasia e a imagem do corpo) são reativados, e é possível assistir, no momento do desenho, a uma reedição do trabalho de construção do self familiar, por meio da representação na árvore genealógica de um corpo mítico, que conta a história lendária da família.

De acordo com Cuynet (2015), esta técnica funciona como uma expressão da estrutura das alianças psíquicas conscientes e inconscientes que consolidam o espírito de identidade corporal da família, e revela o tipo de relação que cada membro acredita ter com outro. Ao desenhar em conjunto a sua árvore genealógica, o grupo familiar é submetido à necessidade de produzir o seu autorretrato. O desenho favorece, assim, a conscientização do grupo familiar acerca de seu funcionamento, no momento em que a família vê o resultado de seu trabalho conjunto. Desta forma, o desenho da árvore genealógica funciona como uma projeção do aparelho psíquico familiar, fruto de sua intersubjetividade e da interfantasmatização, tornandose um lugar de continência para a experiência grupal da família. Pela sua função de representatividade, exterioriza e torna simbólicas as trocas e as transformações psíquicas vividas no espaço familiar: é um "espelho coletivo" que retorna aos membros da família a imagem da sua totalidade (Cuynet et. al., 2006).

Cuynet e Mariage (2004) descrevem que a aplicação da Genografia Projetiva deve ser realizada com no mínimo duas gerações da família presentes. Uma folha branca é apresentada à família no sentido vertical, visível a todos, e as seguintes instruções são enunciadas: “Desenhem juntos a árvore genealógica da sua família. Vocês podem fazer o desenho de acordo 
com a sua imaginação, e são totalmente livres para dar a ele a forma que quiserem nesta folha. Pedimos que façam seus comentários e que deem suas explicações em voz alta, para que possamos compreender o seu desenho da melhor forma possível. Podem relatar datas de nascimentos, falecimentos, acontecimentos marcantes. Por razões de anonimato, podem substituir os nomes de família por uma letra.”

O desenho deve ser realizado com um pincel atômico preto. Todos os comentários feitos pelos membros da família são registrados pelo aplicador, que deve evitar qualquer reação, comentários e observações, caso a família não se dirija a ele. O processo dura em média 1 hora. Ao final do desenho, é realizado um breve inquérito a respeito das impressões da família em relação à sua produção, questionando também sobre quem se parece mais com o filho adolescente na árvore genealógica apresentada, quem seria a pessoa mais importante daquela árvore e quem estaria mais preocupado com o adolescente naquele momento. A Genografia Projetiva Familiar mostra-se, assim, como um instrumento que possibilita a interpretação da vivência familiar, auxiliando na compreensão da estrutura inconsciente básica da família.

A Espaciografia Projetiva Familiar, por sua vez, propõe o desenho de uma "casa dos sonhos", também realizado por toda a família em conjunto, a partir do qual se procura fazer um diagnóstico da estrutura inconsciente das relações familiares. A aplicação desta técnica é sempre precedida pela Entrevista Sobre o Habitat Familiar, a qual introduz temas a serem evocados pela família para a construção da "casa dos sonhos". Segundo Cuynet (2017), esta técnica foi elaborada numa tentativa de investigar as múltiplas representações emocionais presentes na ideia de casa e habitação: de habitar-se, habitar um outro, habitar com o outro. Este instrumento, concebido para uso clínico-terapêutico ou diagnóstico, busca auxiliar na compreensão da estrutura interna e do funcionamento psíquico da célula familiar, concebida como um corpo psíquico organizado. As relações intersubjetivas do grupo são representadas espacialmente sob a forma de lugares, como zonas simbólicas que carregam de modo consciente ou inconsciente traços da existência de conflitos e ligações afetivas da família.

Conforme propõe Cuynet (2017), a família funciona para o indivíduo como sua primeira entidade psíquica de um Eu unificado. A imagem do corpo familiar traduz esse invólucro, no âmbito da fantasia, em que o grupo familiar se insere, funcionando como um envelope psíquico que aglutina o indivíduo e o grupo familiar. Esta representação das experiências emocionais vividas pela família é retratada no desenho da casa dos sonhos, como um diagrama das relações e alianças entre os membros, que permite a expressão daquilo que é impensável ou se encontra em estado mental bruto acerca das suas vivências primitivas. 
Segundo Cuynet (2017), a espacialização do aparelho psíquico em sua forma coletiva é concretizada principalmente nos objetos da realidade que possuem uma função de continência, como o local de habitação da família. Neste lugar são depositados e replicados os traços das experiências das gerações originárias, atravessando o eixo temporal e atualizando-o no presente. A transmissão psíquica dessas experiências emocionais pode acontecer por meio de atos e comportamentos, da língua, mas também pelas marcas deixadas no âmbito da realidade, e que subsistem no habitat familiar. Cada moradia, seja permanente ou temporária, mostra-se como um símbolo do grupo familiar, que deixa neste ambiente suas marcas relativas aos seus modos de ser e de pensar (Cuynet, 2017).

A aplicação da Espaciografia Projetiva Familiar ocorre após uma breve entrevista acerca do local de habitação da família, a partir da instrução pelo aplicador: "Desenhem em família a casa ideal dos seus sonhos. Podem imaginá-la como quiserem, em forma de uma planta baixa." Como o desenho anterior, este também deve ser realizado com um pincel atômico preto, e todos os comentários feitos pelos membros da família são registrados pelo aplicador, que evita manifestar-se caso a família não se dirija a ele. O processo dura em média uma hora. Ao final do desenho, é realizado um breve inquérito a respeito das impressões da família em relação à sua produção, questionando também sobre os motivos de ela constituir-se como a casa dos sonhos da família, quais seriam os lugares mais importantes naquela casa, se haveria objetos herdados e o que levariam consigo em caso de sua destruição.

Cuynet et al. (2016) assinalam que, por meio dessa construção coletiva de uma casa ideal, a família toma forma nos limites de uma figura, na circunferência de uma imagem corporal inconsciente. Ao desenhar a casa, há a expressão do desejo dos sujeitos de habitar um lugar que os represente. Esse habitat idealizado feito em família funcionaria, portanto, como uma espacialização das relações, um eco da construção da unidade familiar num espaço configurado de acordo com os processos inconscientes. O desenho da "casa dos sonhos", além de ajudar a compreender o modo com que a família o seu lugar de vida, permitindo um acesso à estrutura inconsciente da psique familiar, oferece também uma oportunidade de transformação, dando aos "habitantes" uma possibilidade de reocupar o seu espaço pessoal, sem arriscar o desmoronamento da relação familiar (Cuynet et al., 2016).

Cuynet (2017) afirma que o investimento afetivo do espaço de moradia ocorre por meio de uma projeção narcísica da imagem do corpo dos indivíduos que vivem neste lugar. A partir da função onírica do grupo familiar, da sua capacidade de fantasiar em conjunto, o pesquisador ou terapeuta poderá, por meio da Espaciografia Projetiva, recepcionar o eco da configuração 
dessas alianças psíquicas do grupo familiar, que estão relacionadas a um passado inter e transgeracional compartilhado. Pois a casa, e sobretudo o modo como a família a habita, está conectada a uma memória cultural e histórica específica desse grupo.

A casa é tratada pelo homem como um espaço de conforto, que concentra e defende a intimidade. O convite a desenhar uma casa leva, portanto, a uma projeção dessa vivência íntima que um indivíduo experimenta ao habitar um espaço e ao compartilhá-lo com outros. Neste processo, são evocados momentos arcaicos da construção do eu e da imagem corporal, dos primeiros envelopes psíquicos de continência do indivíduo. Retomando as ideias de Anzieu (1989), Cuynet (2017) sugere que o desenho da casa é uma representação simbólica do envelope psíquico familiar, assim como a pele funciona como um envelope individual, pois proporciona continência. Ao desenhar uma casa, projeta-se a imagem inconsciente do corpo, capaz de suportar a própria intimidade e identidade.

Uma função da casa que é evocada neste processo é a de proteger o grupo contra o ambiente externo hostil. A casa que é destruída ou atacada, como ocorre em situações de guerra, ameaça o sentimento de integridade do grupo, seja este uma família ou, mais amplamente, um povo. O exílio é mais uma forma de potencializar essa desintegração identitária, pois o indivíduo ou o grupo é destituído de suas raízes habitacionais. Assim, ao viver em uma casa, o homem busca segurança e integração em diversas formas, concretas e simbólicas.

Desta forma, Cuynet (2017) considera que, por meio da Espaciografia Projetiva Familiar, é possível evidenciar a ligação entre corpo vivido e espaço pensado, o que leva a um entendimento acerca da conexão entre estrutura inconsciente familiar e a dinâmica do investimento das configurações espaciais, ilustrada pelo grupo em suas produções gráficas.

Devido à importância da influência da família no desenvolvimento do indivíduo, essas técnicas oferecem a possibilidade de uma maior compreensão da dinâmica das relações (Cuynet et al, 2006; Kaës, 2014). As técnicas das quais dispomos até o momento para o diagnóstico e a avaliação familiar são predominantemente focadas no indivíduo, em suas relações de objeto internas ou na inferência destas a partir de suas relações com os objetos externos. Quando utilizadas com a intenção de conhecer e intervir terapeuticamente na dinâmica familiar, é costume aplicá-las individualmente nos membros da família e relacionar os dados obtidos para alcançar uma visão mais global.

Nas técnicas propostas por Cuynet $(2015 ; 2017)$, contudo, a tarefa é apresentada a todos os membros da família em conjunto, ou seja, para que eles a realizem em grupo, o que possibilita o surgimento de dados que não apareceriam nas aplicações individuais, como a 
imagem inconsciente do corpo familiar. Isso possibilita a compreensão da estrutura interna e do funcionamento psíquico da célula familiar. Assim, essas técnicas perpassam os indivíduos e os ultrapassam, possibilitando uma maior compreensão da vivência familiar grupal.

Sendo assim, entende-se que essas técnicas apresentam um grande potencial no auxílio da compreensão das relações familiares e da forma como as alianças inconscientes ocorrem entre os membros da família. São técnicas que acompanham os avanços da teoria psicanalítica, pois englobam as teorias de autores contemporâneos como Kaës (2014), que estudam a família e os vínculos entre os indivíduos, incluindo os avanços da psicanálise no campo do psicodiagnóstico. Essas técnicas conferem maior visibilidade aos processos de transmissão psíquica transgeracional, os quais têm sido muito estudados e discutidos atualmente, podendo auxiliar na compreensão dessas novas ideias acerca da vincularidade e das alianças inconscientes, por meio do acesso às suas manifestações nas relações de uma família.

\subsection{Procedimento}

Inicialmente, com a prévia autorização da Secretaria Municipal de Saúde de Ribeirão Preto e a aprovação do projeto de investigação pelo Comitê de Ética em Pesquisa da Faculdade de Filosofia, Ciências e Letras de Ribeirão Preto da Universidade de São Paulo, processo de número 72589317.6.0000.5407 (Anexo A), realizou-se o contato com a equipe responsável pelo Ambulatório Municipal de Nutrologia da Secretaria de Saúde de Ribeirão Preto. Esse contato teve como intuito apresentar a pesquisa, esclarecer seus objetivos e solicitar a colaboração para a indicação de famílias que poderiam participar do estudo. Posteriormente, foram selecionados, junto à equipe profissional do Ambulatório, casos que se encaixavam nos critérios de inclusão da amostra da pesquisa. Da mesma forma, foram selecionados, de acordo com os critérios de inclusão e exclusão, os casos oriundos da rede de contatos pessoal e social da pesquisadora. O contato com as famílias foi estabelecido por telefone, a fim de apresentar brevemente a pesquisa e realizar o convite para que dela participassem. Em caso de aceite, foi agendado o primeiro encontro na residência dos participantes. Foram contatadas ao todo oito famílias, provenientes do Ambulatório de Nutrologia e de contatos pessoais da pesquisadora, e quatro destas aceitaram participar da pesquisa.

Durante o primeiro encontro com cada família, a pesquisa foi explicada em detalhes, em termos de seus objetivos e procedimentos. Após esclarecidas as dúvidas, foi solicitado o preenchimento, pelo adolescente, de uma Ficha de Identificação (Anexo F), a fim de investigar a existência de critérios de exclusão da amostra que não puderam ser detectados anteriormente. 
Nos casos em que o adolescente apresentasse algum dos critérios de exclusão, seria realizada uma pequena entrevista devolutiva sobre as razões da não continuidade no estudo.

Os participantes maiores de 18 anos formalizaram sua anuência em participar da pesquisa por meio da assinatura do Termo de Consentimento Livre e Esclarecido (TCLE) (Apêndice A). Aos responsáveis pelos participantes menores de 18 anos, foi solicitado que autorizassem sua participação e a do(a) filho (a) pela assinatura de um TCLE específico (Apêndice B). Aos participantes menores de 18 anos, por sua vez, foi solicitado que formalizassem seu acordo em participar da pesquisa por um Termo de Assentimento Livre e Esclarecido (TALE) (Apêndice C). A todos os participantes, solicitou-se que autorizassem ou não o armazenamento dos dados da pesquisa para uso posterior, pelo Termo de Autorização para Armazenamento em Banco de Dados (Apêndice D).

Após essa etapa, foi aplicada nas famílias a Entrevista Sobre a História Familiar e os Hábitos Alimentares (Anexo G); em seguida, no mesmo encontro, foi realizada a Genografia Projetiva (Anexo H). Um segundo encontro foi marcado para a aplicação da Entrevista Sobre o Habitat Familiar (Anexo I), sucedida pela administração da Espaciografia Projetiva (Anexo J). A duração média de cada encontro foi de uma hora e meia. Após a coleta e a análise dos dados, tendo sido finalizado o processo da pesquisa, foi proposta uma entrevista devolutiva para cada família, ainda não realizada. Isto ocorrerá por razões éticas, assim como poderá fornecer uma primeira informação acerca da validade clínica dos instrumentos aplicados, já que não foram ainda padronizados para a população brasileira.

A aplicação dos instrumentos foi realizada nas casas das famílias participantes, em dias e horários acordados com os responsáveis pelos adolescentes, com o material fornecido pela pesquisadora. Foram respeitadas todas as condições básicas necessárias à aplicação de testes psicológicos.

\subsection{Análise de dados}

Inicialmente, realizou-se a interpretação da Entrevista Sobre a História Familiar e os Hábitos Alimentares de cada grupo familiar por meio do método da livre inspeção do material (Trinca, 2013). Esse método consiste na verificação do material clínico coletado em função dos conteúdos e dos processos de cada grupo ou indivíduo participante. Nele não existem roteiros prévios para as interpretações, as quais buscam compreender o que é suscitado diretamente pelo material clínico. Esse procedimento de análise busca realizar uma síntese compreensiva dos aspectos importantes expressos pelos participantes por meio da teoria psicanalítica e da 
experiência clínica do pesquisador. Esse mesmo procedimento de análise foi utilizado para a interpretação dos dados da Entrevista Sobre o Habitat Familiar.

Em seguida procedeu-se à codificação e avaliação dos resultados da Genografia Projetiva Familiar, assim como da Espaciografia Projetiva Familiar, a partir dos guias de análise e interpretação dessas técnicas concebidos por Cuynet $(2015$; 2017) e traduzidos do francês para o português pela pesquisadora (Anexos L e M, respectivamente). Em seguida, a codificação dos significados dos índices propostos nos guias foi associada ao método da livre inspeção do material para a realização de uma interpretação compreensiva, em que foi considerada a experiência vivida pela pesquisadora no contato com as famílias na ocasião das aplicações das duas técnicas projetivas, sendo as informações procedentes dos guias de análise mais um elemento a atentar nesse processo.

Diante disso, a interpretação desses dois instrumentos não se tornou enrijecida devido à existência desses roteiros prévios de análise, tomados como referência em conjunto com as vivências da pesquisadora com seus sujeitos de pesquisa. Utilizou-se o corpo teórico-clínico da psicanálise clássica, contemporânea e vincular como prismas interpretativos para a realização da livre inspeção do material.

Após essas etapas, realizou-se uma síntese diagnóstica interpretativa de cada grupo familiar, integrando as informações das entrevistas e das técnicas projetivas utilizadas. Os casos de todas as famílias foram descritos em sua integralidade no tópico dos Resultados. Por fim, foi elaborada uma síntese interpretativa-compreensiva final de todos os grupos familiares estudados, debatendo as suas semelhanças e diferenças em termos de sua estrutura e dinâmica psíquica, assim como da constituição do corpo psíquico familiar. Esta síntese final foi realizada de forma integrada com o tópico Discussão desta dissertação.

\subsection{Considerações éticas}

Este trabalho foi aprovado pelo Comitê de Ética em Pesquisa da Faculdade de Filosofia, Ciências e Letras de Ribeirão Preto da Universidade de São Paulo, processo de número 72589317.6.0000.5407. A coleta e análise dos dados ocorreram com o devido respeito às exigências estabelecidas pela resolução $n^{0}$ 466/12 do Conselho Nacional de Saúde, que regulamenta a diretrizes básicas para a realização de estudos científicos que envolvam seres humanos (Brasil, 2012). A todos os participantes foi garantida a liberdade de participação, sustentando o seu caráter voluntário, e a possibilidade de desistência e retirada do

consentimento em qualquer etapa da pesquisa. A coleta dos dados ocorreu conforme a 
disponibilidade dos participantes, sem que fossem utilizadas quaisquer técnicas persuasivas visando convencê-los a participar do estudo. Foram garantidos também a ausência de ônus e o sigilo quanto aos resultados, preservando-se a identidade dos participantes no caso de divulgação científica.

Os participantes foram esclarecidos quanto aos objetivos e procedimentos do estudo. Após a certificação de seu entendimento e a clarificação de suas eventuais dúvidas, os participantes maiores de 18 anos formalizaram sua anuência por meio da assinatura do Termo de Consentimento Livre e Esclarecido (Apêndice A). Aos responsáveis pelos participantes menores de 18 anos, foi solicitado que autorizassem sua participação e a dos filhos pela assinatura de um TCLE específico (Apêndice B). Aos participantes menores de 18 anos, por sua vez, foi pedido que formalizassem sua anuência pela assinatura de um Termo de Assentimento Livre e Esclarecido (Apêndice C). Visto que este processo de avaliação levanta questões profundas que podem gerar sentimentos de angústia nos integrantes das famílias participantes, a pesquisadora se propôs a acolhê-los caso ocorresse qualquer situação de sofrimento e, se fosse necessário, a coleta seria interrompida. Não houve, no entanto, nenhuma situação em que esse tipo de apoio tenha sido necessário. Caso fossem constatadas dificuldades psicológicas durante o processo de avaliação, os participantes seriam encaminhados para atendimento psicológico. 
5. RESULTADOS 


\section{CONSIDERAÇÕES FINAIS}

Decifra-me ou devoro-te.

(Machado de Assis)

Nesta pesquisa, buscou-se conhecer a dinâmica psíquica grupal de famílias de adolescentes com o diagnóstico de obesidade, com o propósito de investigar se existiriam associações entre esse quadro de saúde do jovem e suas relações intersubjetivas familiares. Foram utilizados dois instrumentos projetivos, a Genografia Projetiva Familiar e a Espaciografia Projetiva Familiar, assim como entrevistas acerca da história familiar, dos hábitos alimentares e da moradia familiar, a fim de obter uma compreensão abrangente acerca das relações intersubjetivas nas famílias, da constituição de seus contornos psíquicos grupais, dos lugares assumidos no grupo pelo adolescente e seus familiares, assim como do compartilhamento e da transmissão geracional de elementos psíquicos entre os membros da família. Todos os instrumentos foram direcionados ao grupo familiar em conjunto, aplicados em presença de todos os familiares que desejaram participar da investigação, e sua interpretação seguiu os parâmetros propostos por Cuynet (2015, 2017), autor das técnicas projetivas mencionadas, assim como o referencial teórico da psicanálise.

Foi possível observar nas famílias a presença de dinâmicas fusionais, relacionamentos simbióticos e indiferenciação entre os membros, especialmente entre as mães e os filhos, tema que tem sido abordado constantemente na literatura sobre a obesidade infantil e do adolescente. O distanciamento ou enfraquecimento da figura do pai também foi encontrado em todos os casos, assim como um afastamento da família em relação ao mundo externo, confirmando dados presentes na literatura. Além desses elementos, contudo, o discurso das famílias estudadas revelou uma invariante principal: um esforço grupal inconsciente de suprimir das experiências da vida qualquer sensação, percepção e menção à ideia de morte. Há uma dificuldade significativa para realizar lutos, viver separações, viabilizar qualquer movimento de diferenciação entre os membros da família, provocando uma obstrução nos processos de subjetivação deles.

Encontrou-se em todas as famílias um impedimento imperativo à vivência da finitude e dos limites nas experiências mais cotidianas e nas mais fundamentais, o que é passível de conduzir a conjecturas acerca de obstruções ou falhas na vivência edípica. No entanto, o vazio psíquico experimentado por esses jovens estudados, que se estende às suas relações afetivas e à experiência grupal dessas famílias, sugeriu a existência de dificuldades psíquicas mais 
primitivas. As contribuições da psicanálise acerca das relações do indivíduo com seus objetos primordiais, assim como os desenvolvimentos a respeito da transmissão psíquica geracional, possibilitaram um aprofundamento das investigações para além do que tem sido estudado pela literatura sobre as relações familiares nos quadros de obesidade, permitindo criar hipóteses relativas à gênese desse núcleo familiar aglutinado, seu funcionamento e os motivos para sua manutenção.

No amplo contexto emocional de cada família estudada, ressaltam-se a incapacidade e uma recusa inconsciente de viver a perda de seus objetos de amor. A dissolução dos objetos é interditada não apenas pelas psiques individuais, mas como um pacto mantido por toda a família, inviabilizando diversos movimentos psíquicos imprescindíveis à subjetivação. Há uma paralização dos objetos e um movimento de incorporação que os inclui de forma não transformável dentro da mente dos indivíduos. Os processos de simbolização e representação são gravemente perturbados, ocorrendo uma predominância de modos de relacionamento que primam pela inércia e o sedentarismo, como a aglutinação, a contiguidade e a aderência. 


\section{REFERÊNCIAS BIBLIOGRÁFICAS}

Abarca-Gómez, L., Abdeen, Z. A., Hamid, Z. A., Abu-Rmeileh, N. M., Acosta-Cazares, B., Acuin, C., \& Agyemang, C. (2017). Worldwide trends in body-mass index, underweight, overweight, and obesity from 1975 to 2016: a pooled analysis of 2416 population-based measurement studies in 128. 9 million children, adolescents, and adults. The Lancet, 390(10113), 2627-2642.

Adonis (2012). Poemas. Organização e tradução de Michel Sleiman. São Paulo: Companhia das Letras.

Aiello-Vaisberg, T. M. J. (1995). O uso de procedimentos projetivos na pesquisa de representações sociais: Projeção e transicionalidade. Psicologia USP, 6(2), 103-127.

Aiello-Vaisberg, T. M. J., \& Machado, M. C. L. (2008). Pesquisa psicanalítica de imaginários coletivos à luz da teoria dos campos. In J. Monzani \& L. R. Monzani (Orgs), Olhar: Fabio Herrmann - Uma viagem psicanalítica. São Paulo, SP: UFSCar.

Akay, A. P., Ozturk, Y., Avcil, S. N., Kavurma, C. \& Tufan, E. (2015). Relationships between pediatric obesity and maternal emotional states and attitudes. The International Journal of Psychiatry in Medicine, 50(2), 178-190.

Andrade, C. D. de. (2012). Antologia poética. São Paulo: Companhia das Letras.

Anzieu, D. (1986). O conceito de projeção em psicologia. In D. Anzieu (Org.), Os métodos projetivos (pp. 15-34). Rio de Janeiro, RJ Campus.

Anzieu, D. (1989). O Eu-Pele. São Paulo, SP: Casa do Psicólogo.

Assis, M. (1995). Memórias Póstumas de Brás Cubas. São Paulo, SP: Nova Cultural. (Trabalho original publicado em 1881).

Aulagnier, P. (1975). A violência da interpretação: do criptograma ao enunciado. Rio de Janeiro, RJ: Imago.

Barbieri, V. (2008). Por uma ciência-profissão: o psicodiagnóstico interventivo como método de investigação científica. Psicologia em Estudo Maringá, 13(3), 575-584.

Benghozi, P. (2007). La trace et l'empreinte: L'adolescent, héritier porte l'empreinte de la transmission généalogique. Adolescence, 62, 755-777.

Bick, E. (1991). A experiência da pele em relações de objeto arcaicas. In E. B. Spillius (Org.), Melanie Klein hoje: Desenvolvimento da teoria e da técnica (pp. 194-198). Rio de Janeiro, RJ: Imago. (Trabalho original publicado em 1967)

Bion, W. R. (1991). Atenção e interpretação: o acesso científico à intuição em psicanálise e grupos. Rio de Janeiro, RJ: Imago. (Trabalho original publicado em 1970). 
Bion, W. R. (1994). Diferenciação entre a personalidade psicótica e a personalidade nãopsicótica. In W. R. Bion, Estudos psicanalíticos revisados (pp. 55-77). Rio de Janeiro, RJ: Imago.

Bion, W. R. (2004). Elementos de psicanálise (J. Salomão \& P. D. Corrêa, trads.). Rio de Janeiro, RJ: Imago. (Trabalho original publicado em 1963).

Bion, W. R. (2013). On arrogance. The Psychoanalytic Quarterly, 82(2), 277-283. (Trabalho original publicado em 1957).

Bion, W.R. (1959). Attacks on linking. International Journal of Psychoanalysis, 40, 308-315.

Birman, J. (2003). Freud \& a filosofia (Vol. 27). Rio de Janeiro, RJ: Zahar.

Bleger, J. (1975) Simbiosis y Ambigüedad. Buenos Aires: Paidós.

Brandão, J. D. S. (1986). Mitologia grega. Volume I. Petrópolis, RJ: Vozes.

Brasil. Ministério da Saúde. (2012). Resolução $n^{o}$ 466/12 sobre pesquisa envolvendo seres humanos. Brasília, DF: Conselho Nacional de Saúde.

Bunge, M. (2018). La ciencia: su método y su filosofia (Vol. 1). Pamplona: Laetoli.

Caballero, B., \& Popkin, M. (2002). Introduction. In B. Caballero \& M. Popkin (Eds.), The nutritional transition: Diet and disease in the developing world. London: Academic Press.

Camargo, A. P. P. M., Barros Filho, A. A., Antonio, M. A. R. G. M., \& Giglio, J. S. (2013). A não percepção da obesidade pode ser um obstáculo no papel das mães de cuidar de seus filhos. Ciência \& Saúde Coletiva. 18(2), 323-333.

Campana, N. T. C., Gomes, I. C., \& Lerner, R. (2014). Contribuições da clínica da parentalidade no atendimento de um caso de obesidade infantil. Psicologia Clínica, 26(2), 105-119.

Candi, T. S. (2010). O duplo limite: o aparelho psíquico de André Green. São Paulo, SP: Escuta.

Candi, T. S. (2011). Limite e simbolização: a influência das ideias de Winnicott na elaboração do conceito de limite de André Green. Revista Brasileira de Psicanálise, 45(4), 119128.

Canelas Neto, J. M. (2013). Reflexão sobre o vazio dentro da psicanálise: do horror do vazio ao vazio criador de metáforas. Jornal de Psicanálise, 46(85), 127-140.

Castanho, P. (2015). O conceito de alianças inconscientes como fundamento para o trabalho vincular em psicanálise. Estudos Interdisciplinares em Psicologia, 6(2), 92-112.

Centers for Disease Control and Prevention. (2018). Defining childhood obesity. Recuperado em 27 de agosto de 2019, de: https://www.cdc.gov/obesity/childhood/defining.html.

Chatelard, D. S., \& Cerqueira, A. C. (2015). O conceito de simbiose em psicanálise: uma revisão de literatura. Ágora: Estudos em Teoria Psicanalítica, 18(2), 257-271. 
Cintra, E. U. (1999). Em parte alguma o mundo existirá. Revista Latinoamericana de Psicopatologia Fundamental, 2(2), 177-190.

Coelho Junior, N. E. (2015). Figuras da terceiridade na psicanálise contemporânea: suas origens e seus destinos. Cadernos de psicanálise, 37(32), 175-195.

Conte, B. (2004). Reflexões sobre o método e a metodologia em psicanálise. Revista da Sociedade de Psicologia do Rio Grande do Sul, 1(3), 6-10.

Correa, O. B. R. (2000). Eclosão dos vínculos genealógicos e transmissão psíquica. In O. B. R. Correa (Org.), Os avatares da transmissão psíquica geracional (pp. 61-71). São Paulo, SP: Escuta.

Correa, O. B. R. (2003). Transmissão psíquica entre as gerações. Psicologia Usp, 14(3), 3545.

Cuynet P. (1998). L'arbre généalogique en Thérapie Familiale Psychanalytique. Le Divan Familial, 1, 77-91.

Cuynet, P. (1999). La maison familiale. Le Divan Familial, 3, 59-71.

Cuynet, P. (2015). L’arbre généalogique en famille. Médium projectif groupal. Paris: In Press.

Cuynet, P. (2017). La maison de rêve. Image du corps familial et habitat. Paris: In Press.

Cuynet, P., \& Mariage, A. (2004). Le dessin de l'arbre généalogique comme épreuve projective. Le Divan Familial, 2(13), 161-182.

Cuynet, P., Mariage, A., Lami, J. A., Faggion, M., Puthomme, S., \& Vannier, A. (2006). L'arbre généalogique, une création familiale. Le Divan Familial, 17(2), 55-68.

Cuynet, P., Schwailbold, M. A., Sanahuja, A., Bernard, A., Derbal, F., \& Ruet, A. (2016). La "maison de rêve": topique projective du corps familial. Dialogue, 213(3), 53-58.

Durski, L. M., \& Safra, G. (2016). O Eu-pele: contribuições de Didier Anzieu para a clínica da psicanálise. Reverso, 38(71), 107-113.

Eiguer, A. (1985). Um divã para a família. Porto Alegre, RS: Artmed.

Faimberg, H. (2000). SBPdePA Entrevista Haydée Faimberg. Psicanálise: Revista da Sociedade Brasileira de Psicanálise de Porto Alegre, 2 (1), 249-266.

Fédida, P. (1975). Une parole qui ne remplit rien. Nouvelle Revue de Psychanalyse, 11, 91101.

Fédida, P. (1999) Depressão. São Paulo, SP: Escuta.

Ferenczi, S. (1955). On the definition of Introjection. In S. Ferenczi, Final contributions to the problems and methods of Psycho-analysis (pp. 316-318). New York: Brunner Mazel. (Trabalho original publicado em 1912). 
Figueiredo, L. C. (2007). A metapsicologia do cuidado. Psychê, 11(21), 13-30.

Figueiredo, L. C., \& Minerbo, M. (2006). Pesquisa em psicanálise: algumas ideias e um exemplo. Jornal de Psicanálise, 39(70), 257-278.

Fisberg, M., Maximino, P., Kain, J., \& Kovalskys, I. (2016). Ambiente obesogênico: oportunidades de intervenção. Jornal de Pediatria, 92(3), 30-39.

Freud, S. (1974). Totem e Tabu. In S. Freud, Edição standard brasileira das obras psicológicas completas de Sigmund Freud, Vol. XIII, pp. 13-194. Rio de Janeiro, RJ: Imago. (Trabalho original publicado em 1913).

Freud, S. (1976). Além do princípio do prazer. In S. Freud, Edição standard brasileira das obras psicológicas completas de Sigmund Freud, Vol. XVIII. Rio de Janeiro, RJ: Imago. (Trabalho original publicado em 1920).

Freud, S. (1976). Construções em análise. In S. Freud, Edição standard brasileira das obras psicológicas completas de Sigmund Freud, Vol. XXIII. Rio de Janeiro, RJ: Imago. (Trabalho original publicado em 1937).

Freud, S. (2006). As neuropsicoses de defesa. In S. Freud, Edição standard brasileira das obras psicológicas completas de Sigmund Freud, Vol. III. Rio de Janeiro, RJ: Imago. (Trabalho original publicado em 1894).

Freud, S. (2006). Luto e melancolia. In S. Freud, Edição standard brasileira das obras psicológicas completas de Sigmund Freud, Vol. XIV. Rio de Janeiro, RJ: Imago. (Trabalho original publicado em 1917).

Freud, S. (2006). Moisés e o monoteísmo: três ensaios. In S. Freud, Edição standard brasileira das obras psicológicas completas de Sigmund Freud, Vol. XXIII. Rio de Janeiro, RJ: Imago. (Trabalho original publicado em 1939).

Garcia-Roza, L. A. (2009). Freud e o inconsciente. Rio de Janeiro, RJ: Zahar.

Golse, B., \& Bydlowiski, M. (2002). Da transparência psíquica à preocupação materna primária: uma via de objetalização. In L. Corrêa Filho; M. H. Corrêa Girade, \& P.

França (Orgs.), Novos olhares sobre a gestação e a criança até 3 anos: saúde perinatal, educação e desenvolvimento do bebê (pp. 215-221). Brasília, DF: L. G. E. Editora.

Granjon, E. (2000). A elaboração do tempo genealógico no espaço do tratamento da terapia familiar psicanalítica. In O. B. R. Correa (Org.), Os avatares da transmissão psíquica geracional (pp. 17-43). São Paulo, SP: Escuta.

Green, A. \& Donnet, J. L. (1973). L'enfant de ça. Paris: Minuit.

Green, A. (1988). Narcisismo de vida, narcisismo de morte. São Paulo, SP: Escuta.

Green, A. (2010). O trabalho do negativo. Porto Alegre, RS: Artmed. 
Green, A. (2014). ¿Por qué las pulsiones de destrucción o de muerte? Buenos Aires: Amorrortu.

Green, A. (2017). O analista, a simbolização e a ausência no contexto analítico. In A. Green, $A$ loucura privada: psicanálise de casos-limite (pp. 69-101). São Paulo, SP: Escuta.

Gregório, G. D. S. (2018). A (im)possivel perda do objeto perdido: o negativo entre a depressão e a depressividade. (Tese de doutorado, Instituto de Psicologia, Universidade de Brasília, Distrito Federal). Recuperado de https://repositorio.unb.br/handle/10482/34347.

Houzel, D. (2004). As implicações da parentalidade. In L. Solis-Ponton (Org.), Ser pai, ser mãe. Parentalidade: um desafio para o terceiro milênio (pp. 47-53). São Paulo, SP: Casa do Psicólogo.

Instituto Brasileiro de Geografia e Estatística. (2014). Pesquisa Nacional de Saúde 2013. Percepção do estado de saúde, estilos de vida e doenças crônicas. Rio de Janeiro, RJ: IBGE.

Jordão, A. B. (2008). Vínculos familiares na adolescência: nuances e vicissitudes na clínica psicanalítica com adolescentes. Aletheia, 27(1), 157-172.

Kaës, R. (2009). As alianças inconscientes. São Paulo, SP: Ideias \& Letras.

Kaës, R. (2011). Um singular plural: A psicanálise à prova do grupo. São Paulo, SP: Loyola.

Kaës, R. (2014). As alianças inconscientes. São Paulo, SP: Ideias \& Letras.

Klein, M. (1991). Notas sobre alguns mecanismos esquizoides. In M. Klein, Inveja e gratidão e outros trabalhos (1946-1963) (pp. 20-43). Rio de Janeiro. RJ: Imago, (Trabalho original publicado em 1946).

Latzer, Y., \& Stein, D. (2013). A review of the psychological and familial perspectives of childhood obesity. Journal of Eating Disorders, 1(7).

Lebovici, S. (1987). O bebê, a mãe e o psicanalista. Porto Alegre, RS: Artes Médicas.

Lemes, S. O. (2004). Acompanhamento da obesidade na infância e adolescência. In M. Fisberg (Coord.), Atualização em obesidade na infância e adolescência. São Paulo, SP: Atheneu.

Lisondo, A. B. D. (2001). Na simbiose patológica, uma concha autística para dois na psicanálise, nasce o ser e a linguagem. In R. B. Graña \& A. B. S. Piva (Orgs.), $A$ atualidade da psicanálise de crianças: perspectivas para um novo século (pp. 165-180). São Paulo: Casa do Psicólogo.

Lisondo, A. B. D. (2010). Rêverie revisitado. Revista Brasileira de Psicanálise, 44(4), 67-84.

Luiz, G. A. M. A., Gorayeb, R., \& Liberatore Júnior, R. D. R. (2010). Avaliação de depressão, problemas de comportamento e competência social em crianças obesas. Estudos de Psicologia, 27(1). 
Mãe, V. H. (2016). O filho de mil homens. Rio de Janeiro, RJ: Globo Livros.

Mahler, M. (1975/1977). O nascimento psicológico da criança: simbiose e individuação. Rio de Janeiro, RJ: Zahar.

McDougall, J. (1984). The "dis-affected" patient: reflections on affect pathology. Psychoanalytic Quarterly, 53(3), 386-409.

Melo, M. E. (2009). Diagnóstico da obesidade infantil. Associação Brasileira para o Estudo da Obesidade e da Síndrome Metabólica (ABESO). Recuperado em https://abeso.org.br/wp-content/uploads/2019/12/552fe98518b8a.pdf.

Meltzer, D. (1975). Identificação adesiva. Jornal de Psicanálise, 19(38), 40-52.

Meltzer, D. (2017). O claustro: uma investigação dos fenômenos claustrofóbicos. São Paulo, SP: Editora Blucher.

Minayo, M. C. S. (2012). Análise qualitativa: teoria, passos e fidedignidade. Ciência \& Saúde Coletiva, 17(3), 621-626.

Ministério da Saúde. Secretaria de Vigilância em Saúde. Departamento de Análise em Saúde e Vigilância de Doenças Não-Transmissíveis (2019). Vigitel Brasil 2018: vigilância de fatores de risco e proteção para doenças crônicas por inquérito telefônico: estimativas sobre frequência e distribuição sociodemográfica de fatores de risco e proteção para doenças crônicas nas capitais dos 26 estados brasileiros e no Distrito Federal em 2018. Brasília, DF: Ministério da Saúde.

Miranda, M. R. (2010). A complexidade da relação mãe-filha nas patologias dos contrários. In C. A. N. B. Bruno (Ed.), Distúrbios alimentares: uma contribuição da psicanálise (pp. 123-154). Rio de Janeiro: Imago.

Mishima, F. K. T. \& Barbieri, V. (2009). O brincar criativo e a obesidade infantil. Estudos de Psicologia, 14(3), 249-255.

Mishima-Gomes, F. K. T., Dezan, S. Z., \& Barbieri, V. (2014). "Não pode!”: a função paterna e a obesidade Infantil. Psico, 45(2), 176-186.

Moraes, P. M., \& Dias, C. M. S. B. (2013). Nem só de pão se vive: a voz das mães na obesidade infantil. Psicologia: Ciência e Profissão, 33(1), 46-59.

Nietzsche, F. (2017). A gaia ciência. São Paulo, SP: Companhia das Letras. (Trabalho original publicado em 1882.)

Novaes, J. V. (2009). Sobre uma falta que o excesso não cobre: reflexões clínicas acerca de uma jovem obesa e suas relações familiares. Revista Mal-Estar e Subjetividade, IX(4), 12531278 .

Ogden, T. H. (1989). The primitive edge of experience. London: Jason Aronson.

Ogden, T. H. (1996). Os sujeitos da psicanálise. São Paulo, SP: Casa do Psicólogo. 
Ogden, T. H. (2010). Sobre sustentar e conter, ser e sonhar. In T. Ogden, Esta arte da psicanálise: sonhando sonhos não sonhados e gritos interrompidos (pp. 121-138). Porto Alegre, RS: Artmed.

Oliveira, L., \& Almeida, P. (2013). Obesidade: aspectos gerais dos fatores, tratamento e prevenção. Voos Revista Polidisciplinar Eletrônica da Faculdade Guairacá, 4. Recuperado em 5 de maio de 2018, de: http://www.revistavoos.com.br/seer/index.php/voos/article/view/224/03 Vol4.2 VOO $\underline{\text { S2012_CL }}$

Padilha, C. R. M. (2019). Transmissão psíquica das experiências transicionais em três gerações de famílias de crianças obesas. (Dissertação de mestrado, Faculdade de Filosofia, Ciências e Letras de Ribeirão Preto, Universidade de São Paulo, São Paulo). Recuperado de https://teses.usp.br/teses/disponiveis/59/59141/tde-16102019114733/pt-br.php.

Petri, A. (2012, 8 de maio). Maurice Sendak and childhood - we ate it up, we loved it. Washington Post. Recuperado de https://www.washingtonpost.com/blogs/compost/post/maurice-sendak-and-childhood-we-ate-it-up-we-loved-it/2012/05/08/gIQAhfcwAU_blog.html

Piva, A. B. (2006). Fundamentos teóricos e técnicos pa-a uma psicanálise vincular. In A. B. Piva \& cols, Transmissão transgeracional e a clínica vincular (pp. 215-234). São Paulo, SP: Casa do Psicólogo.

Puget, J. (2000). Disso não se fala... Transmissão e memória. In O. B. R. Correa (Org.), Os avatares da transmissão psíquica geracional (pp. 73-87). São Paulo, SP: Escuta.

Pulgarón, E. R. (2013). Childhood obesity: a review of increased risk for physical and psychological comorbidities. Clinical Therapeutics, 35(1), A18-A32.

Ramalho, J. A. M., Lachal, J., Bucher-Maluschke, J. S. N. F., Moro, M. R., \& Revah-Levy, A. (2016). A qualitative study of the role of food in family relationships: an insight into the families of Brazilian obese adolescents using photo elicitation. Appetite, 96, 539-545.

Rehbein, M. P., \& Chatelard, D. S. (2013). Transgeracionalidade psíquica: uma revisão de literatura. Fractal: Revista de Psicologia, 25(3), 563-583.

Roussillon, R. (2008). L'entreje(u) primitif et l'homossexualité primaire "en Double". In R. Roussillon, Le jeu et l'entre-je(u) (pp. 117-134). Paris: P.U.F.

Safranski, R. (2011). Schopenhauer: e os anos mais selvagens da filosofia. São Paulo, SP: Geração Editorial.

Sais, L. A. (2011). Odisseia XIX: Penélope anfitriã. Letras Clássicas, 15, 62-77.

Sanahuja, A., \& Cuynet, P. (2011). Image du corps chez l'adolescent obèse et transmission transgénérationnelle. Le Divan Familial, 27(2), 81-94.

Sanahuja, A., Schwailbold, M. A., \& Cuynet, P. (2014). Maigrir à l'adolescence: d'un processus de décontenance du corps familial à un enveloppement institutionnel. Dialogue, 206(4), 47-59. 
Santos, N. D. T. G., \& Zornig, S. A. J. (2014). Primeiros tempos da maternidade: indiferenciação ou intersubjetividade na relação primitiva com o bebê? Estilos da Clinica, 19(1), 78-90.

Silva, C. M. D., \& Macedo, M. M. K. (2016). O método psicanalítico de pesquisa e a potencialidade dos fatos clínicos. Psicologia: ciência e profissão, 36(3), 520-533.

Starc, G., \& Strel, J. (2010). Tracking excess weight and obesity from childhood to young adulthood: A 12-year prospective cohort study in Slovenia. Public Health Nutrition, 15, $1-7$.

Stern, D. (2004). The present moment in psychotherapy and everyday life. London: Brunner-Mazel.

Tassara, V., Norton R. C., \& Marques, W. E. U. (2010). Importância do contexto sociofamiliar na abordagem de crianças obesas. Revista Paulista de Pediatria, 28(3), 309-14.

Tenorio, A. S., \& Cobayashi, F. (2011). Obesidade infantil na percepção dos pais. Revista Paulista de Pediatria. 29(4), 634-9.

Torok, M., \& Abraham, N. (1995). A casca e o núcleo. São Paulo, SP: Escuta.

Trachtenberg, A. R. C. (2007). A força da transmissão entre gerações e o transgeracional. Psicanálise. 9(2), 341-354.

Trinca, W. (2013). Procedimento de Desenhos-Estórias: formas derivadas, desenvolvimentos e expansões. São Paulo, SP: Vetor.

Turato, E. R. (2003). Tratado da metodologia da pesquisa clínico-qualitativa. Petrópolis, RJ: Vozes.

Turato, E. R. (2005). Métodos qualitativos e quantitativos na área da saúde: definições, diferenças e seus objetos de pesquisa. Revista de Saúde Pública, 39(3), 507-514.

Ungar, V. (2015). Adolescência: A dor de pertencer e a dor de não pertencer. In I JornadaInterface da Psicanálise da Criança e Adolescente com a Psicanálise da Vincularidade de Família e Casal. São Paulo, SP: Sociedade Brasileira de Psicanálise de São Paulo.

Urribarri, F. (2012). André Green: o pai na teoria e na clínica contemporânea. Jornal de Psicanálise, 45(82), 143-159.

Vasconcelos, A. T. N. D., \& Lima, M. C. P. (2015). Considerações psicanalíticas sobre a herança psíquica: uma revisão de literatura. Cadernos de psicanálise (Rio de Janeiro), 37(32), 83-103.

Vieira Filho, N. G., \& Teixeira, V. M. S. (2003). Observação clínica: estudo da implicação psicoafetiva. Psicologia em Estudo, 8(1), 23-29.

Vila, C. M. (2006). La complejidad de lo "femenino" (una mirada neo-kleiniana). Desde el jardin de Freud, (6), 146-159. 
Vilhena, J. (1991). Viver juntos nos mata: Separarmo-nos é mortal. A ilusão grupal e a incapacidade de ficar só. In J. Vilhena (Org.), Escutando a família: Uma abordagem psicanalítica (pp. 11-27). Rio de Janeiro, RJ: Relume Dumará.

Winnicott, D. W. (1975). O brincar e a realidade. Rio de Janeiro, RJ: Imago. (Trabalho original publicado em 1971).

Winnicott, D. W. (1975). O papel de espelho da mãe e da família no desenvolvimento infantil. In D. W. Winnicott, $O$ brincar e a realidade (pp. 153-162). Rio de Janeiro, RJ: Imago. (Trabalho original publicado em 1967).

Winnicott, D. W. (1978). Desenvolvimento emocional primitivo. In D. W. Winnicott, Da pediatria a psicanálise (pp. 269-285). Rio de Janeiro, RJ: Francisco Alves. (Trabalho original publicado em 1945).

Winnicott, D. W. (1982). A criança e o seu mundo. Rio de Janeiro, RJ: Livros Técnicos e Científicos. (Trabalho original publicado em 1964).

Winnicott, D. W. (2000). A preocupação materna primária. In D. W. Winnicott, Da pediatria à psicanálise: obras escolhidas (pp. 399-405). Rio de Janeiro, RJ: Imago. (Trabalho original publicado em 1956).

World Health Organization. (2018). Obesity and overweight. World Health Organization. Recuperado de: http://www.who.int/en/news-room/fact-sheets/detail/obesity-andoverweight.

Xavier, M. O., Bielemann, R. M., Maciel, F. V., Neutzling, M. B., \& Gigante, D. P. (2014). Variação temporal no excesso de peso e Obesidade em adolescentes de escola privada do Sul do Brasil. Revista Brasileira de Atividade Física e Saúde, 19(1), 74-85.

Yin, R. K. (2015). Estudo de caso: Planejamento e métodos. Porto Alegre, RS: Bookman.

Zimerman, D. E. (2010). Os quatro vínculos: Amor, ódio, conhecimento e reconhecimento na psicanálise e em nossas vidas. Porto Alegre, RS: Artmed.

Zimmer, R. B. (2013). Arrogance and surprise in psychoanalytic process. The Psychoanalytic Quarterly, 82(2), 393-412.

Zornig, S. (2012). Construção da parentalidade: da infância dos pais ao nascimento do filho. In C. Piccinini, \& P. Alvarenga (Orgs.), Maternidade e paternidade: a parentalidade em diferentes contextos (pp. 17-35). São Paulo, SP: Casa do Psicólogo.

Zornig, S. M. A. J. (2014). O abuso de substâncias tóxicas na adolescência: uma tentativa de incorporação do objeto?. Ágora: Estudos em Teoria Psicanalítica, 17(SPE), 5162.

Zornig, S. M. A. J. (2015). Clínica dos primórdios e processos de simbolização primários. Psicologia Clínica, 27(2), 121-136. 


\section{APÊNDICES}

\section{APÊNDICE A - Termo de consentimento livre e esclarecido (familiares maiores de 18 anos)}

Você está sendo convidado(a) a participar da pesquisa: Psicodinamismos e imagem inconsciente do corpo familiar em famílias de adolescentes obesos, que está sendo desenvolvida por mim, psicóloga e aluna do curso de mestrado em Psicologia da Faculdade de Filosofia, Ciências e Letras de Ribeirão Preto da Universidade de São Paulo (FFCLRP-USP), sob a orientação da $\operatorname{Prof}^{a}$ Dr $^{\mathrm{a}}$ Valeria Barbieri do Departamento de Psicologia desta mesma faculdade.

Por meio desta pesquisa, pretendemos compreender as relações familiares de adolescentes que apresentam obesidade. Para isto, precisamos da colaboração de adolescentes e suas famílias, e gostaríamos que você participasse deste estudo.

Para participar desta pesquisa você deve estar ciente de que sua participação é voluntária e sua recusa não implicará em prejuízos para você ou sua família. As informações que você fornecer poderão ser apresentadas em eventos científicos e publicadas em periódicos científicos, porém sempre mantendo o seu anonimato, de modo que sua identidade será preservada. Essas informações serão armazenadas em um banco de dados dos pesquisadores.

Caso você aceite este convite, realizaremos dois encontros com você e sua família, em uma sala reservada no Ambulatório Municipal de Nutrologia da Secretaria de Saúde de Ribeirão Preto, em horário de sua conveniência. No primeiro encontro, a pesquisa será explicada a você e sua família, e vocês preencherão uma ficha de identificação. Conforme as respostas, poderão prosseguir para a realização de uma entrevista com você e sua família, em que conversaremos um pouco sobre seus relacionamentos familiares e sua história com a alimentação; em seguida, vocês farão juntos um desenho relacionado à sua história familiar. No segundo encontro, será realizada outra entrevista com você e sua família, em que conversaremos a respeito da relação que vocês têm com sua moradia; por fim, vocês farão juntos outro desenho, relacionado ao tema da moradia familiar. Essas atividades contribuirão para o entendimento sobre suas relações familiares.

Durante cada encontro, será utilizado um gravador de áudio, para termos certeza de que você e sua família foram bem compreendidos. Ao dar seu consentimento, você também estará concordando com o fato de que essas gravações sejam transcritas e que o material produzido seja utilizado para fins de pesquisa, preservando os valores éticos quanto aos dados fornecidos, de acordo com as diretrizes que regem a realização de pesquisas com seres humanos.

No decorrer dos encontros, caso você queira descansar, podemos parar a qualquer momento por algum tempo até que você esteja disposto(a) a continuar. Cada encontro tem uma duração prevista de 60 minutos, podendo variar para mais ou para menos.

Esta pesquisa não prevê benefícios diretos a você, como remuneração ou outra vantagem especial. Providenciaremos o ressarcimento de eventuais despesas que você possa ter, decorrentes da participação nesta pesquisa. Sua participação auxiliará os profissionais de saúde a compreenderem melhor as relações familiares de adolescentes com Obesidade e, a partir dessas informações, esses profissionais poderão auxiliar no aprimoramento dos programas de atenção dirigidos a essa população.

Não há riscos significativos em participar dessa pesquisa. Contudo, algumas questões abordadas podem causar algum tipo de angústia ou desconforto psicológico. Caso isso aconteça, você poderá conversar com a equipe de psicologia do Ambulatório de Nutrologia ou solicitar um encontro com um dos pesquisadores envolvidos no projeto.

Você é livre para desistir de participar da pesquisa a qualquer momento, bastando comunicar se esta for sua vontade. A desistência não implicará em consequências negativas para você, não causará prejuízos ou interrupção nos tratamentos que sua família estiver realizando.

Ao aceitar participar deste estudo, é importante que você saiba que tem direito de receber esclarecimentos antes, durante e após a realização da pesquisa. Se você tiver qualquer dúvida quanto aos procedimentos deste estudo, elas poderão ser esclarecidas a qualquer momento. Basta entrar em contato comigo ou com minha orientadora, por meio dos e-mails carolfpina@gmail.com ou valeriab@ffclrp.usp.br ou pelos telefones (16) 3102-4749 ou (16) 99632-5079, das 9 às 17 horas, de segunda a sexta-feira. O endereço profissional meu e de minha orientadora é: Departamento de Psicologia, Bloco 5, sala 5 da Faculdade de Filosofia, Ciências e Letras de Ribeirão Preto da 
Universidade de São Paulo, situada à Avenida Bandeirantes, 3900, Monte Alegre, 14040-901, Ribeirão Preto-SP.

Este estudo foi aprovado pelo Comitê de Ética em Pesquisa da Faculdade de Filosofia, Ciências e Letras de Ribeirão Preto da Universidade de São Paulo. Caso tenha necessidade de obter algum esclarecimento adicional sobre os aspectos éticos deste estudo, você pode entrar em contato com esse Comitê no seguinte endereço: Comitê de Ética em Pesquisa da Faculdade de Filosofia, Ciências e Letras de Ribeirão Preto - USP, Avenida Bandeirantes, 3900 - Bloco 01 - Prédio da Administração - sala 07 - 14040-901 - Ribeirão Preto-SP - Brasil, com horário de atendimento das $13 \mathrm{~h} 30$ às 17h30, fone: (16) 3315-4811, e-mail: coetp@,ffclrp.usp.br.

Agradecemos a sua atenção e nos colocamos à disposição para os esclarecimentos que você desejar.

Considerando o que foi explicado acima, declaro que:

Fui informado(a) de que a minha participação nesta pesquisa é inteiramente voluntária, podendo ser interrompida a qualquer momento, sem que isso possa acarretar qualquer tipo de consequência negativa para mim. Estou ciente de que minha participação será registrada por meio de gravações de áudio, com o que consinto voluntariamente, desde que as mesmas sejam utilizadas com objetivos de pesquisa. Estou ciente de que a divulgação do material produzido irá resguardar meu anonimato. Estou ciente também de que todo material derivado de minha colaboração será utilizado com objetivo exclusivo de pesquisa e que serão tomados os demais cuidados éticos necessários para preservar meus direitos à intimidade e dignidade pessoal. Fui informado(a) ainda que a pesquisadora responsável por esse projeto poderá realizar apresentações em eventos científicos, bem como publicar os resultados deste estudo em periódicos científicos, respeitando-se os limites éticos aqui afirmados.

Considero que fui esclarecido(a) em minhas dúvidas a respeito deste estudo e estou informado(a) de que tenho a disponibilidade da pesquisadora para prestar esclarecimentos em relação a eventuais dúvidas que possam surgir no decorrer da pesquisa. Também estou ciente de que terei acesso aos resultados deste estudo após sua conclusão, caso eu tenha interesse, e que posso retirar a minha concordância em qualquer etapa da pesquisa.

Considerando o exposto, aceito participar voluntariamente deste estudo.

$\mathrm{Eu}$, (nome do/da participante), recebi uma via assinada deste Termo e tive a possibilidade de lê-lo com atenção antes de firmá-lo, depois do que aceitei participar neste estudo, sabendo que tal participação é livre e inteiramente voluntária.

Data: de de 201

Assinatura do(a) participante:

Assinatura da pesquisadora:

Ana Carolina Fortes Paiva de Pina

Mestranda em Psicologia da FFCLRP-USP

Assinatura da orientadora:

Prof. ${ }^{\text {a }}$ Dr. ${ }^{\text {a }}$ Valeria Barbieri FFCLRP-USP 
APÊNDICE B - Termo de consentimento livre e esclarecido (responsáveis pelos adolescentes menores de 18 anos)

Seu(s) filho(s) está(estão) sendo convidado(s) a participar da pesquisa: Psicodinamismos e imagem inconsciente do corpo familiar em famílias de adolescentes obesos, que está sendo desenvolvida por mim, psicóloga e aluna do curso de mestrado em Psicologia da Faculdade de Filosofia, Ciências e Letras de Ribeirão Preto da Universidade de São Paulo (FFCLRP-USP), sob a orientação da Prof. ${ }^{a}$ Dr. ${ }^{a}$ Valeria Barbieri do Departamento de Psicologia desta mesma faculdade.

Por meio desta pesquisa, pretendemos compreender as relações familiares de adolescentes que apresentam Obesidade. Para isto, precisamos da colaboração de adolescentes e suas famílias, e gostaríamos que você e seu(s) filho(s) participassem deste estudo.

Para participar desta pesquisa você deve estar ciente de que a participação de vocês é voluntária e sua recusa não implicará em nenhum tipo de consequência ou prejuízo para você nem para seu(s) filho(s). As informações que você e seu(s) filho(s) fornecerem poderão ser apresentadas em eventos científicos e publicadas em periódicos científicos, porém sempre mantendo o anonimato, de modo que a identidade de vocês será preservada. Essas informações serão armazenadas em um banco de dados dos pesquisadores.

Caso vocês aceitem este convite, realizaremos dois encontros com você, seu(s) filho(s) e sua família, em uma sala reservada no Ambulatório Municipal de Nutrologia da Secretaria de Saúde de Ribeirão Preto, em horário de sua conveniência. No primeiro encontro, a pesquisa será explicada a você e sua família, e vocês preencherão uma ficha de identificação. Conforme as respostas, poderão prosseguir para a realização de uma entrevista com você e sua família, em que conversaremos um pouco sobre seus relacionamentos familiares e sua história com a alimentação; em seguida, vocês farão juntos um desenho relacionado à sua história familiar. No segundo encontro, será realizada outra entrevista com vocês e sua família, em que conversaremos a respeito da relação que vocês têm com sua moradia; por fim, vocês farão juntos outro desenho, relacionado ao tema da moradia familiar. Essas atividades contribuirão para o entendimento sobre suas relações familiares.

Durante cada encontro, será utilizado um gravador de áudio, para termos certeza de que vocês e sua família foram bem compreendidos. Ao dar seu consentimento, você também estará concordando com o fato de que as gravações realizadas em áudio sejam transcritas e que o material produzido possa ser utilizado exclusivamente para fins de pesquisa, preservando os valores éticos quanto aos dados fornecidos, de acordo com as diretrizes que regem a realização de pesquisas com seres humanos.

No decorrer dos encontros, caso você ou seu(s) filho(s) queira(m) descansar, podemos parar a qualquer momento por algum tempo até que vocês estejam dispostos a continuar. Cada encontro tem uma duração prevista de 60 minutos, podendo variar para mais ou para menos. Esta pesquisa não prevê benefícios diretos a você ou a seu(s) filho(s), como remuneração ou outra vantagem especial. Providenciaremos o ressarcimento de eventuais despesas que você possa ter, decorrentes da participação nesta pesquisa. A participação de vocês auxiliará os profissionais de saúde a compreenderem melhor as relações familiares de adolescentes com obesidade e, a partir dessas informações, esses profissionais poderão auxiliar no aprimoramento dos programas de atenção dirigidos a essa população.

Não há riscos significativos em participar dessa pesquisa. Contudo, algumas questões abordadas podem causar algum tipo de angústia ou desconforto psicológico. Caso isso aconteça, você ou seu(s) filho(s) poderá(ão) conversar com a equipe de psicologia encarregada do atendimento dela ou solicitar um encontro com um dos pesquisadores envolvidos no projeto.

Você e seu(s) filho(s) são livres para desistir de participar da pesquisa a qualquer momento, bastando comunicar se essa for sua vontade. A desistência não implicará em consequências para você, nem causará prejuízos ou interrupção nos tratamentos que seu(s) fillho(s) está(ão) realizando.

Ao aceitar participar deste estudo, é importante que você saiba que tem direito de receber esclarecimentos antes, durante e após a realização da pesquisa. Se você tiver qualquer dúvida quanto aos procedimentos deste estudo, elas poderão ser esclarecidas a qualquer momento. Basta entrar em contato comigo ou com minha orientadora, por meio dos e-mails carolfpina@gmail.com ou valeriab@ffflrp.usp.br ou pelos telefones (16) 3102-4749 ou (16) 99632-5079, das 9 às 17 horas, de segunda a sexta-feira. $\mathrm{O}$ endereço profissional meu e de minha orientadora é: Departamento de Psicologia, Bloco 5, sala 5 da Faculdade de Filosofia, Ciências e Letras de Ribeirão Preto da 
Universidade de São Paulo, situada à Avenida Bandeirantes, 3900, Monte Alegre, 14040-901, Ribeirão Preto-SP.

Este estudo foi aprovado pelo Comitê de Ética em Pesquisa da Faculdade de Filosofia, Ciências e Letras de Ribeirão Preto da Universidade de São Paulo. Caso tenha necessidade de obter algum esclarecimento adicional sobre os aspectos éticos deste estudo, você pode entrar em contato com esse Comitê no seguinte endereço: Comitê de Ética em Pesquisa da Faculdade de Filosofia, Ciências e Letras de Ribeirão Preto - USP, Avenida Bandeirantes, 3900 - Bloco 01 - Prédio da Administração - sala 07 - 14040-901 - Ribeirão Preto-SP - Brasil, com horário de atendimento das $13 \mathrm{~h} 30$ às 17h30, fone: (16) 3315-4811, e-mail: coetp@,ffclrp.usp.br.

Agradecemos a sua atenção e colocamo-nos à disposição para os esclarecimentos que você necessitar.

Considerando o que foi explicado acima, declaro que:

Fui informado(a) de que a participação de meu(s) filho(s) nesta pesquisa é inteiramente voluntária, podendo ser interrompida a qualquer momento, sem que isso possa acarretar qualquer tipo de consequência para ele(s) ou para mim. Estou ciente de que sua participação será registrada por meio de gravações de áudio, com o que consinto, desde que as mesmas sejam utilizadas com objetivos de pesquisa. Estou ciente de que a divulgação do material produzido irá resguardar o anonimato de meu(s) filho(s). Estou ciente também de que todo material derivado de sua colaboração será utilizado com objetivo exclusivo de pesquisa e que serão tomados os demais cuidados éticos necessários para preservar seus direitos à intimidade e dignidade pessoal. Fui informado(a) ainda que a pesquisadora responsável por esse projeto poderá realizar apresentações em eventos científicos, bem como publicar os resultados deste estudo em periódicos científicos, respeitando-se os limites éticos aqui afirmados.

Considero que fui esclarecido(a) em minhas dúvidas a respeito deste estudo e estou informado(a) de que tenho a disponibilidade da pesquisadora para prestar esclarecimentos em relação a eventuais dúvidas que possam surgir no decorrer da participação de meu(s) filho(s) nesta pesquisa. Também estou ciente de que terei acesso aos resultados deste estudo após sua conclusão, caso eu tenha interesse, e que posso retirar minha concordância em qualquer etapa da pesquisa.

Considerando o exposto, aceito participar voluntariamente deste estudo.

$\mathrm{Eu}$, (nome do responsável), recebi uma via deste Termo e tive a possibilidade de lê-lo com atenção antes de firmá-lo, após o que consenti com a participação de meu(s) filho(s) no estudo, sabendo que tal participação é livre e voluntária.

Data: de de 201

Assinatura do(a) participante:

Assinatura da pesquisadora:

Ana Carolina Fortes Paiva de Pina

Mestranda em Psicologia da FFCLRP-USP

Assinatura da orientadora:

\author{
Prof. ${ }^{a}$ Dr. ${ }^{a}$ Valeria Barbieri \\ FFCLRP-USP
}


APÊNDICE C - Termo de assentimento livre e esclarecido (participantes menores de 18 anos)

Você está sendo convidado(a) a participar da pesquisa: Psicodinamismos e imagem inconsciente do corpo familiar em famílias de adolescentes obesos, que está sendo desenvolvida por mim, psicóloga e aluna do curso de mestrado em Psicologia da Faculdade de Filosofia, Ciências e Letras de Ribeirão Preto da Universidade de São Paulo (FFCLRP-USP), sob a orientação da Prof. ${ }^{a}$ Dr. ${ }^{a}$ Valeria Barbieri do Departamento de Psicologia desta mesma faculdade.

Por meio desta pesquisa, pretendemos compreender as relações familiares de adolescentes que apresentam obesidade. Para isto, precisamos da colaboração de adolescentes e suas famílias, e gostaríamos que você participasse deste estudo. Nós já solicitamos a autorização de seus pais para que você possa participar da pesquisa, caso você queira.

Para participar desta pesquisa você deve estar ciente de que sua participação é voluntária e sua recusa não implicará em consequências negativas ou prejuízos para você ou sua família. As informações que você fornecer poderão ser apresentadas em eventos científicos e publicadas em periódicos científicos, porém sempre mantendo o seu anonimato, de modo que sua identidade será preservada. Essas informações serão armazenadas em um banco de dados dos pesquisadores.

Caso você aceite este convite, realizaremos dois encontros com você e sua família, em uma sala reservada no Ambulatório Municipal de Nutrologia da Secretaria de Saúde de Ribeirão Preto, em horário de sua conveniência. No primeiro encontro, a pesquisa será explicada a você e sua família, e vocês preencherão uma ficha de identificação. Conforme as respostas, poderão prosseguir para a realização de uma entrevista com você e sua família, em que conversaremos um pouco sobre seus relacionamentos familiares e sua história com a alimentação; em seguida, vocês farão juntos um desenho relacionado à sua história familiar. No segundo encontro, será realizada outra entrevista com você e sua família, em que conversaremos a respeito da relação que vocês têm com sua moradia; por fim, vocês farão juntos outro desenho, relacionado ao tema da moradia familiar. Essas atividades contribuirão para o entendimento sobre suas relações familiares.

Durante cada encontro, será utilizado um gravador de áudio, para termos certeza de que você e sua família foram bem compreendidos. Ao dar seu consentimento, você também estará concordando com o fato de que as gravações realizadas em áudio sejam transcritas e que o material produzido possa ser utilizado exclusivamente para fins de pesquisa, preservando os valores éticos quanto aos dados fornecidos, de acordo com as diretrizes que regem a realização de pesquisas com seres humanos.

No decorrer dos encontros, caso você queira descansar, podemos, a qualquer momento, parar por algum tempo até que você esteja disposto(a) a continuar. Cada encontro tem uma duração prevista de 60 minutos, podendo variar para mais ou para menos. Esta pesquisa não prevê benefícios diretos a você, como remuneração ou outra vantagem especial. Providenciaremos o ressarcimento de eventuais despesas que você possa ter, decorrentes da participação nesta pesquisa. Sua participação auxiliará os profissionais de saúde a compreenderem melhor as relações familiares dos adolescentes com obesidade e, a partir dessas informações, esses profissionais poderão auxiliar no aprimoramento dos programas de atenção dirigidos a essa população.

Não há riscos significativos em participar dessa pesquisa. Contudo, algumas questões abordadas podem causar algum tipo de angústia ou desconforto psicológico. Caso isso aconteça, você poderá conversar com a equipe de psicologia do Ambulatório de Nutrologia ou solicitar um encontro com um dos pesquisadores envolvidos no projeto. Você é livre para desistir de participar da pesquisa a qualquer momento, bastando comunicar o seu desejo. A desistência não implicará em consequências negativas para você, nem causará prejuízos ou interrupção nos tratamentos que sua família está realizando.

Ao aceitar participar deste estudo, é importante que você saiba que tem direito de receber esclarecimentos antes, durante e após a realização da pesquisa. Se você tiver qualquer dúvida quanto aos procedimentos deste estudo, elas poderão ser esclarecidas a qualquer momento. Basta entrar em contato comigo ou com minha orientadora, por meio dos e-mails carolfpina@gmail.com ou valeriab@fffclrp.usp.br ou pelos telefones (16) 3102-4749 ou (16) 99632-5079, das 8 às 17 horas, de segunda à sexta-feira. $\mathrm{O}$ endereço profissional meu e de minha orientadora é: Departamento de Psicologia, Bloco 5, sala 5 da Faculdade de Filosofia, Ciências e Letras de Ribeirão Preto da Universidade de São Paulo, situada à Avenida Bandeirantes, 3900, Monte Alegre, 14040-901, Ribeirão Preto-SP. 
Este estudo foi aprovado pelo Comitê de Ética em Pesquisa da Faculdade de Filosofia, Ciências e Letras de Ribeirão Preto da Universidade de São Paulo. Caso tenha necessidade de obter algum esclarecimento adicional sobre os aspectos éticos deste estudo, você pode entrar em contato com esse Comitê no seguinte endereço: Comitê de Ética em Pesquisa da Faculdade de Filosofia, Ciências e Letras de Ribeirão Preto - USP, Avenida Bandeirantes, 3900 - Bloco 01 - Prédio da Administração - sala 07 - 14040-901 - Ribeirão Preto-SP - Brasil, com horário de atendimento das $13 \mathrm{~h} 30$ às 17h30, fone: (16) 3315-4811, e-mail: coetp@ffclrp.usp.br.

Agradecemos a sua atenção e colocamo-nos à disposição para os esclarecimentos que você necessitar.

Considerando o que foi explicado acima, declaro que:

Fui informado(a) de que a minha participação nesta pesquisa é inteiramente voluntária, podendo ser interrompida a qualquer momento, sem que isso possa acarretar qualquer tipo de consequência negativa para mim. Estou ciente de que minha participação será registrada por meio de gravações de áudio, com o que consinto voluntariamente, desde que as mesmas sejam utilizadas com objetivos de pesquisa. Estou ciente de que a divulgação do material produzido irá resguardar meu anonimato. Estou ciente também de que todo material derivado de minha colaboração será utilizado com objetivo exclusivo de pesquisa e que serão tomados os demais cuidados éticos necessários para preservar meus direitos à intimidade e dignidade pessoal. Fui informado(a) ainda que a pesquisadora responsável por esse projeto poderá realizar apresentações em eventos científicos, bem como publicar os resultados deste estudo em periódicos científicos, respeitando-se os limites éticos aqui afirmados.

Considero que fui esclarecido(a) em minhas dúvidas a respeito deste estudo e estou informado(a) de que tenho a disponibilidade da pesquisadora para prestar esclarecimentos em relação a eventuais dúvidas que possam surgir no decorrer da pesquisa. Também estou ciente de que terei acesso aos resultados deste estudo após sua conclusão, caso eu tenha interesse, e que posso retirar a minha concordância em qualquer etapa da pesquisa.

Considerando o exposto, aceito participar voluntariamente deste estudo.

$\mathrm{Eu}$,

(nome do/da participante), recebi uma via assinada deste Termo e tive a possibilidade de lê-lo com atenção antes de firmá-lo, depois do que aceitei participar neste estudo, sabendo que tal participação é livre e inteiramente voluntária.

Data: __ de de 201

Assinatura do(a) participante:

Assinatura da pesquisadora:

Ana Carolina Fortes Paiva de Pina

Mestranda em Psicologia da FFCLRP-USP

Assinatura da orientadora:

\author{
Prof. ${ }^{\text {a }}$ Dr. ${ }^{\text {a }}$ Valeria Barbieri \\ FFCLRP-USP
}


APÊNDICE D - Termo de autorização para armazenamento em banco de dados (Todos os participantes)

Entendendo que você aceitou participar da pesquisa Psicodinamismos e imagem inconsciente do corpo familiar em famílias de adolescentes obesos, o propósito deste documento é solicitar sua permissão para que as informações as informações que foram fornecidas nas entrevistas e nos procedimentos com desenhos feitos por você e sua família possam ser guardadas, com vista a constituir o que nós pesquisadores chamamos de "banco de dados". Banco de Dados é o armazenamento de informações de uma pesquisa, como esta que estou realizando, para que essas informações sejam utilizadas, em termos científicos, em outras pesquisas, na mesma área de interesse.

As informações serão armazenadas na Faculdade de Filosofia, Ciências e Letras de Ribeirão Preto, sob a responsabilidade da Professora Valéria Barbieri. Após o término deste estudo, se você concordar, iremos armazenar em um banco de dados as informações que foram fornecidas nas entrevistas e nos procedimentos com desenhos feitos por você e sua família. Isso significa que essas informações serão guardadas para que, no futuro, possam ser integradas com dados da outra pesquisa maior, que permitirá ampliar o nosso conhecimento sobre a obesidade. É importante que você saiba que o uso das suas informações em pesquisas futuras somente será feito com o seu consentimento, sendo que você poderá escolher se deseja ser informado sobre cada nova pesquisa que será feita utilizando esses dados, e se autoriza ou não este uso.

As únicas pessoas que terão acesso a esse banco de dados são os docentes envolvidos na pesquisa e qualquer uso dessas informações por outros pesquisadores somente poderá ser feito dentro do grupo de pesquisa desses professores, sob a responsabilidade deles e com a autorização sua e deles. Da mesma forma que ocorrerá durante a pesquisa, o sigilo quanto à sua identidade será sempre mantido. Solicitamos então que você preencha a questão que consta no final deste Termo de Autorização para Armazenamento em Banco de Dados sobre se autoriza ou não esse armazenamento de suas informações, e se deseja ser informado ou não sobre novas pesquisas que utilizam seus dados.

Caso deseje, você pode ter acesso aos resultados obtidos nesta pesquisa maior; para isso, entre em contato com as pesquisadoras responsáveis por meio dos e-mails valeriab@ffclrp.usp.br ou carolfpina@gmail.com, ou ainda pelos telefones (16)3315-3798 ou (16)99632-5079, das 8 às 17 horas, de segunda à sexta-feira. $\mathrm{O}$ endereço profissional das pesquisadoras é: Departamento de Psicologia, Bloco 5, salas 5 da Faculdade de Filosofia, Ciências e Letras de Ribeirão Preto da Universidade de São Paulo, situada à Avenida Bandeirantes, 3900, Monte Alegre, 14040-901 - Ribeirão Preto - SP.

Diante do exposto, declaro que estou ciente das informações recebidas e que:

( ) Autorizo o armazenamento de minhas informações no banco de dados dos docentes após a conclusão desta pesquisa.

( ) Não autorizo o armazenamento de minhas informações no banco de dados dos docentes após a conclusão desta pesquisa.

( ) Quero ser avisado sempre que meus dados forem utilizados em futuras pesquisas.

( ) Não quero ser avisado quando meus dados forem utilizados em futuras pesquisas.

Data: de de 201

Assinatura do(a) participante:

Assinatura da pesquisadora:

Ana Carolina Fortes Paiva de Pina

Mestranda em Psicologia da FFCLRP-USP

Assinatura da coordenadora do projeto:

Prof. ${ }^{\text {a }}$ Dr. ${ }^{\text {a }}$ Valeria Barbieri (FFCLRP-USP) 


\section{ANEXOS}

ANEXO A - Carta de aprovação do Comitê de Ética em Pesquisa da FFCLRP-USP

Prezado(a) Pesquisador(a),

Comunicamos a V. Sa. que o projeto de pesquisa intitulado "A constituição da imagem inconsciente do corpo familiar na família do adolescente obeso" foi analisado pelo Comitê de Ética em Pesquisa da FFCLRP-USP, em sua $173^{a}$ Reunião Ordinária, realizada em 14.12.2017, e enquadrado na categoria: APROVADO (CAAE n 72589317.6.0000.5407).

Solicitamos que eventuais modificações ou emendas ao projeto de pesquisa sejam apresentadas ao CEP, de forma sucinta, identificando a parte do projeto a ser modificada e suas justificativas. De acordo com a Resolução n466 de 12/12/2012, devem ser entregues relatórios semestrais e, ao término do estudo, um relatório final sempre via Plataforma Brasil.

Atenciosamente,

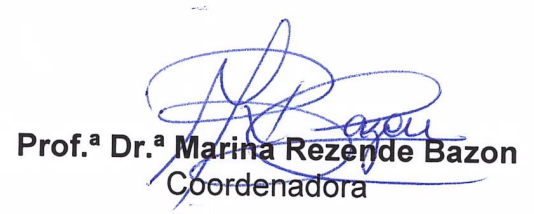

Ao(À) Senhor(a)

Ana Carolina Fortes Paiva de Pina

Programa de Pós-graduação em Psicologia da FFCLRP/USP

CEP - Comitê de Ética em Pesquisa da FFCLRP USP

Fone: (16) 3315-4811 Avenida Bandeirantes, 3900 - bloco 01 da Administração - sala 07
14040-901 - Ribeirão Preto - SP - Brasil

Homepage: http://www.ffclrp.usp.br - e-mail: coetp@ffclrp.usp.br 
ANEXO B -. Declaração de aceite de instituição coparticipante (Secretaria Municipal de Saúde de Ribeirão Preto)

\section{Prefeitura Municipal de Ribeirão Preto}

Estado de São Paulo - Secretaria Municipal da Saúde

OF2299 /2017- CAPP

CV/2017

Ribeirão Preto, 08 de junho de 2017.

Prezado Senhora Orientadora

Informamos que a coordenadora da Comissão de Avaliação Projeto de Pesquisa manifestou a concordância com a coleta de dados do projeto: "A CONSTITUIÇÃO DA IMAGEM INCONSCIENTE DO CORPO FAMILIAR NA FAMÍLIA DO ADOLESCENTE OBESO " sob a orientação do Professora DRA VALERIA BARBIERI no Núcleo de Gestão Assistencial - Ambulatório de Nutrologia.

Sendo assim, declaro estar ciente e concordo com a realização do projeto de pesquisa na Secretaria Municipal da Saúde de Ribeirão Preto-SP.

Informo que a pesquisa somente poderá iniciar quando obtiver a aprovação do Comitê de Ética em Pesquisa da instituição proponente.

Solicito que a pesquisadora encaminhe à Secretaria Municipal da Saúde o Relatório Final ao encerrar a pesquisa.

$$
\begin{aligned}
& \text { Cordialmente, } \\
& \text { Dra. Claudia Siqueira Vassimon } \\
& \text { Coordenadora da Comissão de Avaliação de Projeto de Pesquisa } \\
& \text { da Secretaria Municipal de Saúde de Ribeirão Preto-CAPP }
\end{aligned}
$$

Ilustrissima Senhora

PROFa. DRA VALERIA BARBIERI

ORIENTADORA DO PROJETO DE PESQUISA

FACULDADE DE FILOSOFIA CIÊNCIAS E LETRAS

NESTA 
ANEXO C - Organização Mundial da Saúde - Gráfico de IMC-por-idade: 5 a 19 anos de idade (feminino)

BMI-for-age GIRLS

5 to 19 years (percentiles)

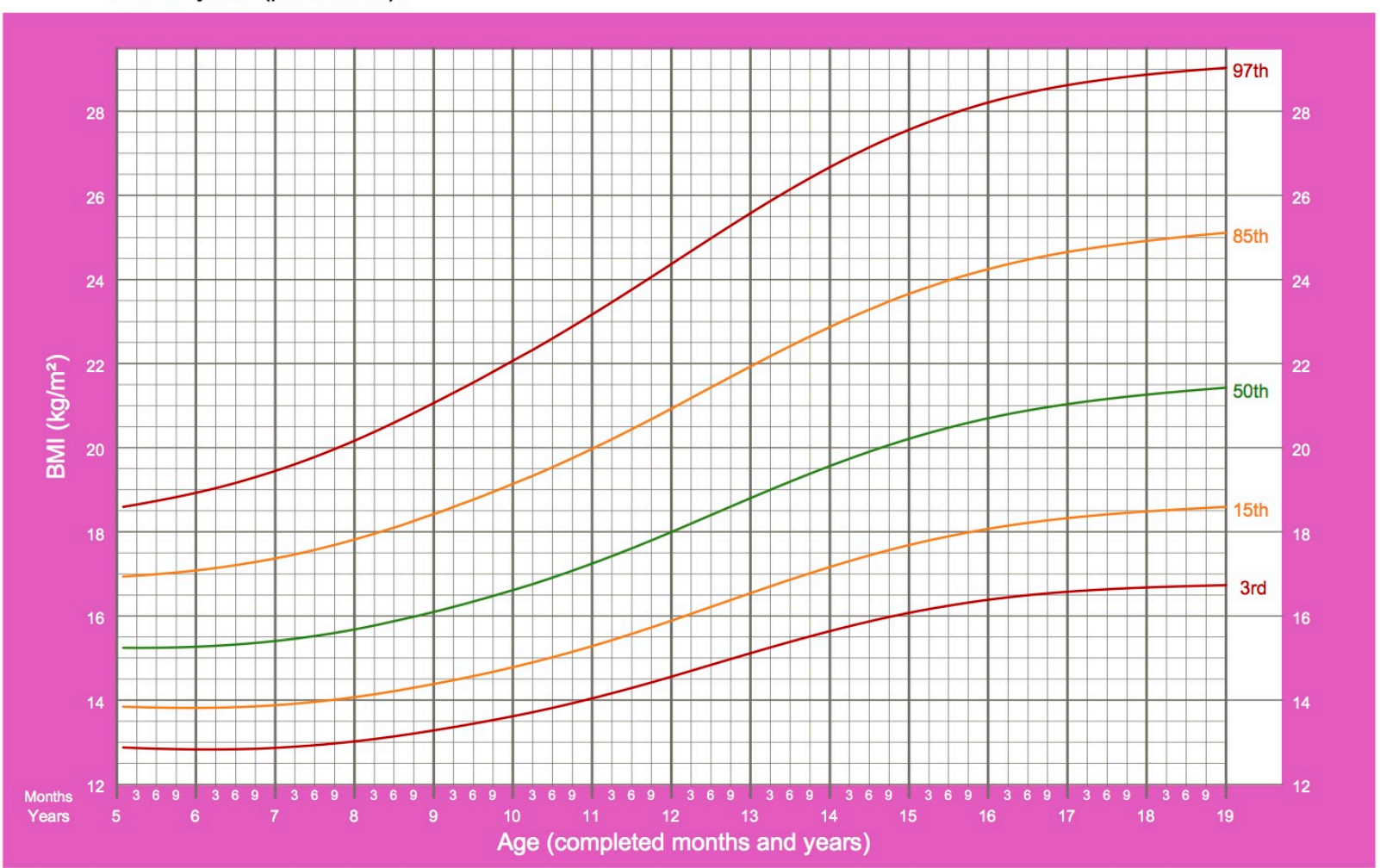

2007 WHO Reference 
ANEXO D - Organização Mundial da Saúde - Gráfico de IMC-por-idade: 5 a 19 anos de idade (masculino)

\section{BMI-for-age BOYS}

5 to 19 years (percentiles)

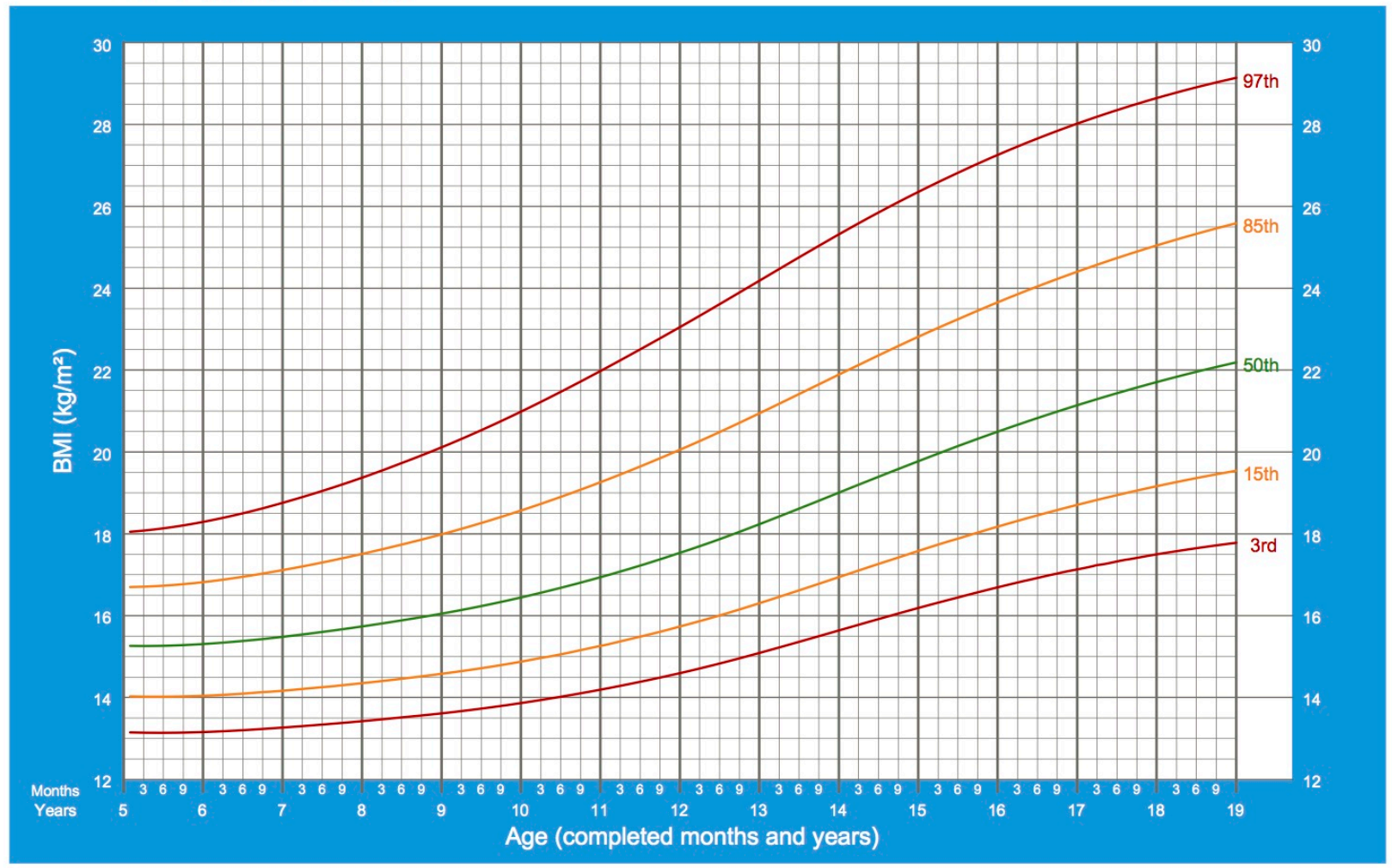

2007 WHO Reference 
ANEXO E - Ficha de Identificação da Família

Nome do Adolescente:

Idade:

Sexo:

Escolaridade:

Peso e altura:

IMC-por-idade:

Ordem do nascimento:

Nome do Pai:

Idade:

Escolaridade:

Profissão:

Peso e altura:

Telefone para contato:

Endereço:

Nome da Mãe:

Idade:

Escolaridade:

Profissão:

Peso e altura:

Telefone para contato:

Endereço:

Irmãos:

\begin{tabular}{|l|l|l|l|l|}
\hline Nome & & & & \\
\hline $\begin{array}{l}\text { Ordem do } \\
\text { nascimento }\end{array}$ & & & & \\
\hline Sexo & & & & \\
\hline Idade & & & & \\
\hline Escolaridade & & & & \\
\hline Profissão & & & & \\
\hline
\end{tabular}




\section{ANEXO F - Entrevista Sobre a História Familiar e Hábitos Alimentares}

Aplicador: Bom-dia. Pedimos que vocês participassem desta investigação com o objetivo de melhor compreender as famílias que buscam atendimento no Ambulatório de Nutrologia e aprofundar o nosso conhecimento sobre da experiência familiar em torno da alimentação. Nós nos encontraremos a fim de nos conhecermos melhor e para que possamos ajudar o melhor possível as famílias que passam pela vivência da Obesidade de um filho adolescente. Com sua permissão, registraremos esta entrevista para facilitar o protocolo da investigação, mas esta gravação permanecerá confidencial e não será utilizada em lugar algum além desta circunstância e sem sua permissão. Vocês têm perguntas ou dúvidas sobre a nossa pesquisa?

Aplicador: Gostaríamos de conhecer como sua família se relaciona com a alimentação, por isso vamos fazer-lhes algumas perguntas, que se referem a todos os membros da sua família aqui presentes. Suas respostas são livres. Vocês todos podem falar e intervir quando desejarem.

Legenda:

$\mathrm{T}$ - Pergunta para Todos

$\mathrm{P}$ - Pergunta para os Pais

F - Pergunta para os Filhos

(I.1) T: Todos estão aqui?

(I.2) T: Quem não pôde vir? Por quê?

(I.3) T: Podem apresentar-se? (Pedir nome, idade, profissão e classe social se não forem fornecidos.)

(I.4) T: Como cada um de vocês está vivendo este processo de buscar atendimento no Ambulatório? (Pergunta especifica para a família dos adolescentes obesos.)

(I.5) T: Como descreveriam as relações entre vocês?

(I.6) T: (Para lembrar coisas mais antigas:) Em qual momento vocês diriam que houve ganho de peso? (Pergunta especifica para a familia dos adolescentes obesos.)

(I.7) T: Em sua opinião, a que isso pode ter se relacionado? (Pergunta especifica para a família dos adolescentes obesos.)

(I.8) T: Como a Obesidade é vivida na família? É possível que alguns sejam afetados mais que outros? (Pergunta específica para a família dos adolescentes obesos.)

(I.9) T: A refeição é um momento importante para a família?

(I.10) T: Quem prepara a comida? Quem decide a refeição? É importante para vocês que todos sejam pontuais às refeições?

(I.11) T: Vocês decidem um menu comum ou cada um come o que deseja? Beliscam durante o dia? Em quais momentos?

(I.12) T: Como acontecem as refeições, qual é o ambiente?

(I.13) T: Alguém já fez regime?

(I.14) T: Vocês tentam controlar seu peso? Como? Têm mais tendência a prestar atenção no que comem ou praticam uma atividade física regular?

(I.15) T: Vocês compartilham atividades em família? Ficam frequentemente juntos?

(I.16) P: Como descreveriam as relações entre seus filhos? F: E vocês, o que acham?

(I.17) P: Expliquem como são compostas suas famílias de origem. De onde vêm?

(I.18) P: A refeição era um momento importante nas suas respectivas famílias de origem? 
(I.19) P: Quem preparava a comida?

(I.20) P: Vocês tinham hábitos à mesa ou expressões recorrentes em torno da refeição?

(I.21) P: Alguns membros da sua família têm, em seu conhecimento, medo da pobreza, da falta ou de passar fome? De ficarem doentes se não comerem frequentemente durante o dia?

(I.22) P: Outros membros da família têm problemas com o peso? Alguém teve algum problema com alimentação (passou fome)? (Específico para famílias de adoelscentes obesos. Para famílias de adolescentes eutróficos, perguntar somente se alguém tem problemas com alimentação.)

(I.23) T: Vocês têm conhecimento de alguém da família que tenha sofrido com condutas de anorexia ou bulimia?

(I.24) P: Como eram as relações na sua família de origem?

(I.25) P: Como descreveriam a sua infância? E sua adolescência?

(I.26) T: Houve acontecimentos marcantes na história da sua família, dos quais vocês estejam cientes? Como se sentem em relação a isso?

(I.27) P: Quais relações vocês têm hoje com a sua família de origem?

(I.28) P: Com que frequência a veem?

(I.29) P: Quais são as relações entre os seus pais e os seus filhos?

(I.30) P: Como se passaram as gravidezes e os nascimentos para cada um de vocês?

(I.31) P: E a amamentação, como se passou? Seu filho (sua filha) bebia bem o leite? Como aconteceu a passagem para as comidas sólidas?

(I.32) P: Como ocorreu a aquisição da higiene?

(I.33) P: Como e por que escolheram os nomes? Quais são os seus outros nomes e de onde vêm?

(I.34) P: Como eram os filhos: entre eles, com vocês, na escola, com os amigos?

(I.35) T: Vocês diriam que alguns acontecimentos marcaram sua vida familiar?

(I.36) F: Vocês sabem como seus pais se conheceram?

(I.37) P: Desde quando vocês são um casal? O que é que fez com que se encontrassem pela primeira vez?

(I.38) P: De que maneira vocês, como um casal, foram aceitos pelas suas famílias? Como podem descrever os princípios ou valores das suas famílias paternas e maternas? 
ANEXO G - Genografia Projetiva Familiar

Aplicador: Para compreender melhor sua organização familiar, peço que desenhem juntos a árvore genealógica da sua família. Vocês podem fazer o desenho de acordo com a sua imaginação, e são totalmente livres para dar a ele a forma que quiserem nesta folha. Pedimos que façam seus comentários e que deem suas explicações em voz alta, para que possamos compreender seu desenho da melhor forma possível. Podem relatar datas de nascimentos, falecimentos, acontecimentos marcantes. Por razões de anonimato, podem substituir os nomes de família por uma letra.

\section{Inquérito:}

( $\mathrm{T}$ - Pergunta para Todos)

T: O que vocês pensam da sua árvore?

T: Vocês diriam que seu filho ou sua filha (referir-se ao adolescente em foco na pesquisa) se assemelha a alguém da família? Fisicamente e em termos de personalidade.

T: Quem seria a pessoa mais importante em toda a família? Por quê?

T: Quem está mais preocupado com o(a) filho(a)? 
ANEXO H - Entrevista Sobre o Habitat Familiar

Aplicador: Para compreender melhor seus hábitos de vida, vamos conversar com vocês sobre a organização do seu espaço familiar, ou seja, como cada um vive dentro da casa.

Legenda:

T - Pergunta para Todos

$\mathrm{P}$ - Pergunta para os Pais

F - Pergunta para os Filhos

(II.1) T: Vocês vivem muito dentro de casa? (Em função das informações da entrevista de anamnese.)

(II.2) T: Em que tipo de moradia vivem? Desde quando?

(II.3) T: Vocês são proprietários ou inquilinos?

(II.4) T: É um lugar novo ou antigo?

(II.5) T: Fizeram reformas? Por quê?

(II.6) P: Quando escolheram sua moradia, o que teve maior peso em sua escolha? A disposição interna ou o aspecto externo, a vista, a vizinhança...?

(II.7) T: Por qual estilo de decoração optaram para seu interior? Por quê?

(II.8) P: Herdaram móveis ou objetos da sua família? O que fizeram com eles? Onde estão?

(II.9) T: Há terreno ao redor da casa?

(II.10) T: Vocês passam tempo na casa? Ela é importante para vocês?

(II.11) T: Vocês têm uma horta? Comem seus próprios legumes? É por preocupação econômica ou por prazer?

(II.12) T: Como vocês viveram suas mudanças?

(II.13) T: Qual pessoa, vocês diriam, é mais apegada à sua moradia? Por quê?

(II.14) T: Qual é o seu cômodo preferido, onde vocês se sentem melhor?

(II.15) T: Vocês ficam frequentemente todos reunidos em casa? Em que lugar da casa? O que fazem lá?

(II.16) T: Existe alguém que passe mais tempo neste lugar do que as outras pessoas?

(II.17) T: Alguém tem a oportunidade de ficar sozinho na casa? Como vivem essa situação?

(II.18) F: Os filhos, têm cada um seu próprio quarto? São eles que cuidam deste quarto?

(II.19) F: Você gosta de ficar no seu quarto? Por quê?

(II.20) T: As portas são frequentemente fechadas?

(II.21) T: Há hábitos na sua família antes de deitar?

(II.22) T: Há alguém que tenha dificuldades para dormir?

(II.23) T: Permanecem muito em casa ou gostam de sair?

(II.24) T: Vocês têm costume de convidar amigos ou preferem ir até a casa deles?

(II.25) T: Que relação vocês têm com seus vizinhos? 
ANEXO I - Espaciografia Projetiva Familiar

Aplicador: Desenhem em família a casa ideal dos seus sonhos. Podem imaginá-la como quiserem, em forma de uma planta baixa.

\section{Inquérito}

( $\mathrm{T}$ - Pergunta para Todos)

T: O que pensam do seu desenho?

T: Por que este desenho se aproxima da casa dos seus sonhos? O que vocês refariam?

T: O que caracteriza uma casa dos sonhos?

T: Qual seria o lugar mais importante nesta casa ideal? (Opinião comum e individual.)

T: Qual seria o objeto a ser levado no caso de destruição da casa? Onde ele estaria?

T: Nesta casa, haveria objetos que procederiam das suas famílias de origem? Onde eles estariam?

T: Qual é a sala onde vocês gostariam de ficar sozinhos? (Colher a opinião de cada um.)

$\mathrm{T}$ : Nesta casa, o que mais define a sua família?

$\mathrm{T}$ : De que materiais é feita esta casa e por quê?

T: Qual é a cor de dentro e por fora?

$\mathrm{T}$ : O que vocês acharam dos nossos encontros? 
ANEXO J - Ficha de Aplicação

Nome:

Data:

Família:

Estão presentes:

Hora do início:

Hora do término:

Aplicador:

Anotar: ordem de realização e reações dos outros membros.

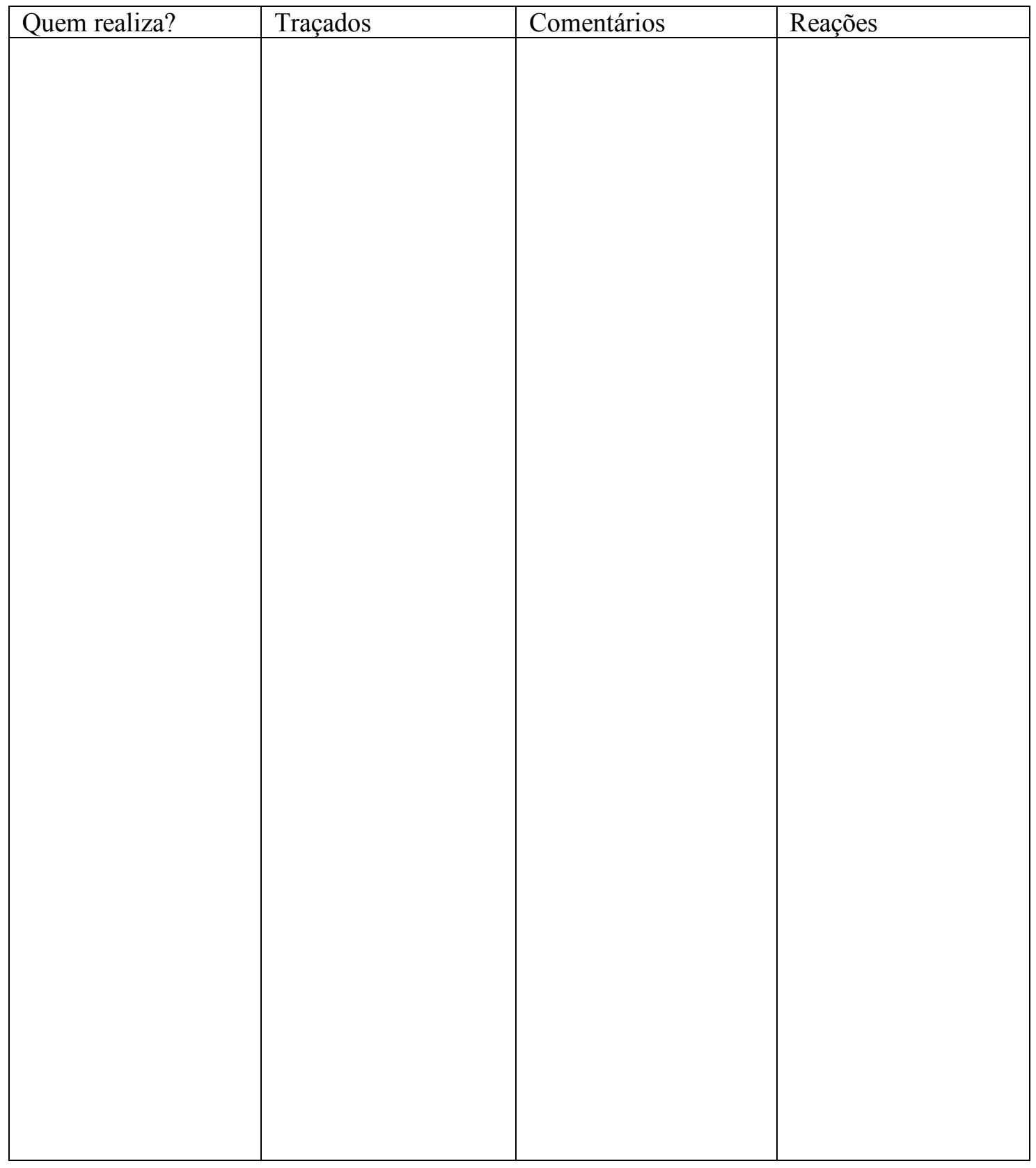



ANEXO K - Guia de cotação e interpretação da Genografia Projetiva Familiar

\begin{tabular}{|c|c|c|}
\hline Item & $\begin{array}{c}\text { Possibilidades e Significado } \\
\text { descritivo }\end{array}$ & Interpretações \\
\hline \multicolumn{3}{|l|}{ 1. Identificação do protocolo } \\
\hline 2. Tentativas de execução & $\begin{array}{l}\text { 1. Primeira tentativa } \\
\text { 2. Segunda tentativa } \\
\text { 3. Terceira tentativa }\end{array}$ & $\begin{array}{l}\text { 1. Capacidade de trabalhar em conjunto } \\
\text { 2. Percepção de um bloqueio; Ato falho ou sinal de uma confusão; Representação de um eu não } \\
\text { integrado. } \\
\text { 3. Pânico e bloqueio. Sinal de angústia. Problema de comunicação. }\end{array}$ \\
\hline 3. Sentido da folha & $\begin{array}{l}\text { 1. Vertical: sentido original } \\
\text { 2. Horizontal: reversão da folha }\end{array}$ & $\begin{array}{l}\text { 1. Concepção de uma verticalidade nas relações de filiação. Filiação diacrônica (a sucessão das } \\
\text { gerações é colocada em evidência). } \\
\text { 2. A descendência está menos presente. Vivem no presente, visão do "aqui e agora". Geração } \\
\text { aplainada. } \\
\text { Sinal de oposição em relação à instrução; Pensamento operatório da família num eixo sincrônico } \\
\text { do "aqui e agora"; Não pensar no peso do passado (evitamento, recusa). }\end{array}$ \\
\hline 4. Espaço ocupado & $\begin{array}{l}\text { 1. Folha inteira: ocupa toda a } \\
\text { superfície da folha. } \\
\text { 2. Padrão: ocupa entre metade e } 3 / 4 \text { da } \\
\text { folha. } \\
\text { 3. Em extensão: ocupa mais de } 3 / 4 \text { da } \\
\text { folha sem preenchê-la totalmente. } \\
\text { 4. Em contração: ocupa menos de } 1 / 4 \\
\text { da folha. }\end{array}$ & $\begin{array}{l}\text { 1. Luta contra o vazio, necessidade de se apoiar sobre as bordas da folha; Expansividade limitada } \\
\text { pelo enquadre da folha; Envelopar-se. } \\
\text { 2. Normalidade; Controle psíquico dos limites; Conformidade. } \\
\text { 3. Lado expansivo e entusiasmado da família; Memória familiar rica; Sinal de dinamismo familiar } \\
\text { e de expressão livre. } \\
\text { 4. Inibição familiar; bloqueio; suspeita de segredos. Na parte superior: reação às tendências } \\
\text { depressivas. Normalidade; controle psíquico dos limites; conformidade. }\end{array}$ \\
\hline $\begin{array}{l}\text { 5. Posição da árvore padrão ou em } \\
\text { contração (verticalmente) }\end{array}$ & $\begin{array}{l}\text { 1. Superior } \\
\text { 2. Central } \\
\text { 3. Inferior }\end{array}$ & $\begin{array}{l}\text { 1. Sinal de otimismo e de confiança; Luta contra a depressão (árvore em contração). } \\
\text { 2. Sinal de conformismo e de controle. Sinal de ansiedade (árvore em contração). } \\
\text { 3. Sinal de depressão, inibição (árvore em contração); Necessidade de apoio (árvore padrão) }\end{array}$ \\
\hline $\begin{array}{l}\text { 6. Posição da árvore padrão ou em } \\
\text { contração (horizontalmente) }\end{array}$ & $\begin{array}{l}\text { 1. Esquerda } \\
\text { 2. Centro } \\
\text { 3. Direita }\end{array}$ & $\begin{array}{l}\text { 1. Família em busca de apoio } \\
\text { 2. Família conformista e sob controle } \\
\text { 3. Família que vai do lado da ação e do futuro }\end{array}$ \\
\hline $\begin{array}{l}\text { 7. Tendência de posição da árvore em } \\
\text { extensão }\end{array}$ & $\begin{array}{l}\text { 1. Esquerda } \\
\text { 2. Centro } \\
\text { 3. Direita }\end{array}$ & $\begin{array}{l}\text { 1. Família em busca de apoio } \\
\text { 2. Família conformista e sob controle } \\
\text { 3. Família que vai do lado da ação e do futuro }\end{array}$ \\
\hline 8. A árvore toca a borda da folha & Sim/Não & Sim: Necessidade de encontrar e de se apoiar sobre limites. \\
\hline 9. O traçado transborda da folha & $\begin{array}{l}\text { 1. No alto } \\
\text { 2. Abaixo } \\
\text { 3. À esquerda } \\
\text { 4. À direita }\end{array}$ & $\begin{array}{l}\text { 1. Impulsividade e Excitação; Eu ideal } \\
\text { 2. Necessidade de apoio } \\
\text { 3. Problemática no lado paterno } \\
\text { 4. Problemática no lado materno, específica ao grupo terapêutico }\end{array}$ \\
\hline 10. Lugar de início do traçado & 1. Superior à Esquerda & 1. Idealização, valorização acompanhada por posição passiva \\
\hline
\end{tabular}




\begin{tabular}{|c|c|c|}
\hline & $\begin{array}{l}\text { 2. Superior ao centro } \\
\text { 3. Superior à direita } \\
\text { 4. Centro à Esquerda } \\
\text { 5. Centro } \\
\text { 6. Centro à Direita } \\
\text { 7. Inferior à Esquerda } \\
\text { 8. Inferior ao Centro } \\
\text { 9. Inferior à Direita }\end{array}$ & $\begin{array}{l}\text { 2. Idealização, valorização afirmadas } \\
\text { 3. Idealizçãao, valorização. Matizado por posição ativa } \\
\text { 4. Equilíbrio matizado por investigação do passado e posição passiva } \\
\text { 5. Ponto de controle e de equilíbrio afirmado } \\
\text { 6. Ponto de controle. Matizado por posição ativa } \\
\text { 7. Regressivo, inibição. Matizado por posição passiva } \\
\text { 8. Regressivo, inibição afirmadas } \\
\text { 9. Regressivo, inibição. Matizado por posição ativa }\end{array}$ \\
\hline 11. Lugar do primeiro nome & $\begin{array}{l}\text { 1. Superior à Esquerda } \\
\text { 2. Superior ao centro } \\
\text { 3. Superior à direita } \\
\text { 4. Centro à Esquerda } \\
\text { 5. Centro } \\
\text { 6. Centro à Direita } \\
\text { 7. Inferior à Esquerda } \\
\text { 8. Inferior ao Centro } \\
\text { 9. Inferior à Direita }\end{array}$ & $\begin{array}{l}\text { 1. Idealização, valorização. Matizado por posição passiva } \\
\text { 2. Idealização, valorização afirmadas } \\
\text { 3. Idealização, valorização. Matizado por posição ativa } \\
\text { 4. Ponto de controle e desequilíbrio. Matizado pela busca do passado e posição passiva } \\
\text { 5. Ponto de controle e busca de equilíbrio } \\
\text { 6. Ponto de controle. Matizado por posição ativa } \\
\text { 7. Inibição, matizada por posição passiva } \\
\text { 8. Regressivo, inibição afirmada } \\
\text { 9. Regressivo, inibição, matizado por posição ativa. Desequilíbrio }\end{array}$ \\
\hline 12. Lugar de fim do desenho & $\begin{array}{l}\text { 1. Superior à Esquerda } \\
\text { 2. Superior ao centro } \\
\text { 3. Superior à direita } \\
\text { 4. Centro à Esquerda } \\
\text { 5. Centro } \\
\text { 6. Centro à Direita } \\
\text { 7. Inferior à Esquerda } \\
\text { 8. Inferior ao Centro } \\
\text { 9. Inferior à Direita }\end{array}$ & $\begin{array}{l}\text { 1. Idealização, valorização. Matizado por posição passiva } \\
\text { 2. Idealização, valorização afirmadas } \\
\text { 3. Idealização, valorização. Matizado por posição ativa } \\
\text { 4. Ponto de controle e desequilíbrio. Matizado por posição passiva } \\
\text { 5. Ponto de controle e de busca do equilíbrio } \\
\text { 6. Ponto de controle. Matizado por posição ativa } \\
\text { 7. Regressivo, inibiçãa. Matizado por posição passiva } \\
\text { 8. Regressivo, inibição afirmada } \\
\text { 9. Regressivo, inibição. Matizado por posição ativa . Desequilíbrio }\end{array}$ \\
\hline 13. Lugar do último nome & $\begin{array}{l}\text { 1. Superior à Esquerda } \\
\text { 2. Superior ao centro } \\
\text { 3. Superior à direita } \\
\text { 4. Centro à Esquerda } \\
\text { 5. Centro } \\
\text { 6. Centro à Direita } \\
\text { 7. Inferior à Esquerda } \\
\text { 8. Inferior ao Centro } \\
\text { 9. Inferior à Direita }\end{array}$ & $\begin{array}{l}\text { 1. Idealização, valorização. Matizado por posição passiva } \\
\text { 2. Idealização, valorização afirmada } \\
\text { 3. Idealização, valorização. Matizado por posição ativa } \\
\text { 4. Ponto de controle e desequilíbrio. Matizado por posição passiva } \\
\text { 5. Ponto de controle e desequilíbrio afirmado } \\
\text { 6. Ponto de controle. Matizado por posição ativa } \\
\text { 7. Regressivo, inibição. Matizado por posição passiva } \\
\text { 8. Regressivo, inibição afirmada } \\
\text { 9. Regressivo, inibição, matizado por posição ativa. Desequilíbrio }\end{array}$ \\
\hline 14. Tipo de família & $\begin{array}{l}\text { 1. Nuclear } \\
\text { 2. Monoparental } \\
\text { 3. Recomposta } \\
\text { 4. Homoparental } \\
\end{array}$ & \\
\hline
\end{tabular}




\begin{tabular}{|c|c|c|}
\hline $\begin{array}{l}\text { 15. Grupo familiar na distribuição } \\
\text { espacial }\end{array}$ & $\begin{array}{l}\text { 1. Reunido: as relações espaciais pais- } \\
\text { crianças sobre a árvore são diretas. } \\
\text { 2. Eclodido: há dispersão da criança e } \\
\text { dos pais. }\end{array}$ & $\begin{array}{l}\text { 1. Existe um Eu unitário da família } \\
\text { 2. Existe um problema de relação ou um problema de identidade, ou de lugar. }\end{array}$ \\
\hline $\begin{array}{l}\text { 16. Posição do pai (grupo familiar } \\
\text { reunido) }\end{array}$ & $\begin{array}{l}\text { 1. Superior à Esquerda } \\
\text { 2. Superior ao Centro } \\
\text { 3. Superior à Direita } \\
\text { 4. Centro à Esquerda } \\
\text { 5. Centro } \\
\text { 6. Centro à Direita } \\
\text { 7. Inferior à Esquerda } \\
\text { 8. Inferior ao centro } \\
\text { 9. Inferior à Direita }\end{array}$ & $\begin{array}{l}\text { A posição do pai = (globalmente função de autoridade). } \\
\text { Matizado por posição na folha mais a posição é baixa menos o pai feito figura de autoridade. }\end{array}$ \\
\hline $\begin{array}{l}\text { 17. Posição da mãe (grupo familiar } \\
\text { reunido) }\end{array}$ & $\begin{array}{l}\text { 1. Superior à Esquerda } \\
\text { 2. Superior ao Centro } \\
\text { 3. Superior à Direita } \\
\text { 4. Centro à Esquerda } \\
\text { 5. Centro } \\
\text { 6. Centro à Direita } \\
\text { 7. Inferior à Esquerda } \\
\text { 8. Inferior ao centro } \\
\text { 9. Inferior à Direita }\end{array}$ & A mãe remonta às funções: simbiótica e de segurança. A matizar em função da posição. \\
\hline $\begin{array}{l}\text { 18. Posição dos filhos (grupo familiar } \\
\text { reunido) }\end{array}$ & $\begin{array}{l}\text { 1. Superior à Esquerda } \\
\text { 2. Superior ao Centro } \\
\text { 3. Superior à Direita } \\
\text { 4. Centro à Esquerda } \\
\text { 5. Centro } \\
\text { 6. Centro à Direita } \\
\text { 7. Inferior à Esquerda } \\
\text { 8. Inferior ao centro } \\
\text { 9. Inferior à Direita }\end{array}$ & $\begin{array}{l}\text { A criança está abaixo dos pais: relação de filiação normal. } \\
\text { Posição narcisista (fetiche) se a criança estiver acima dos pais: auto-engendramento da criança } \\
\text { ou Parentificação. A matizar em função da posição. }\end{array}$ \\
\hline $\begin{array}{l}\text { 19. Lugar da mãe em relação ao pai } \\
\text { (grupo familiar reunido) }\end{array}$ & $\begin{array}{l}\text { 1. Superior } \\
\text { 2. Inferior } \\
\text { 3. Esquerda } \\
\text { 4. Direita }\end{array}$ & $\begin{array}{l}\text { 1. Se a mãe estiver superior em relação ao pai: é a mãe que tem uma função mais importante } \\
\text { 2. Se a mãe estiver inferior em relação ao pai é o pai que exerce uma função mais importante } \\
\text { 3. Se a mãe for situada à esquerda em relação ao pai, ela está numa posição mais passiva } \\
\text { 4. Se a mãe for situada à direita em relação ao pai, ela está numa posição mais ativa }\end{array}$ \\
\hline $\begin{array}{l}\text { 20. Posição do pai (grupo familiar } \\
\text { eclodido) }\end{array}$ & $\begin{array}{l}\text { 1. Superior à Esquerda } \\
\text { 2. Superior ao Centro } \\
\text { 3. Superior à Direita } \\
\text { 4. Centro à Esquerda }\end{array}$ & $\begin{array}{l}\text { 1. Se o pai estiver em posição superior à esquerda em relação à família: está numa posição mais } \\
\text { passiva } \\
\text { 2. Se o pai estiver em posição superior ao centro em relação à família: está numa posição de } \\
\text { controle com uma busca de equilíbrio }\end{array}$ \\
\hline
\end{tabular}




\begin{tabular}{|c|c|c|}
\hline & $\begin{array}{l}\text { 5. Centro } \\
\text { 6. Centro à Direita } \\
\text { 7. Inferior à Esquerda } \\
\text { 8. Inferior ao centro } \\
\text { 9. Inferior à Direita }\end{array}$ & $\begin{array}{l}\text { 3. Se o pai estiver em posição superior à direita em relação à família: está numa posição ativa } \\
\text { 4. Se o pai estiver no centro à esquerda em relação à família: está numa posição de controle } \\
\text { passivo } \\
\text { 5. Se o pai estiver no centro em relação à família: está numa posição de hipercontrole e busca de } \\
\text { equilíbrio } \\
\text { 6. Se o pai estiver no centro à direita em relação à família: está numa posição ativa } \\
\text { 7. Se o pai estiver em posição inferior à esquerda em relação à família: está uma posição passiva, } \\
\text { de submissão e desvalorização } \\
\text { 8. Se o pai estiver numa posição inferior ao centro em relação à família: está numa posição de } \\
\text { submissão controlada } \\
\text { 9. Se o pai estiver numa posição inferior à direita em relação à família: está numa posição de } \\
\text { reação à submissão (luta contra a submissão) }\end{array}$ \\
\hline $\begin{array}{l}\text { 21. Posição da mãe (grupo familiar } \\
\text { eclodido) }\end{array}$ & $\begin{array}{l}\text { 1. Superior à Esquerda } \\
\text { 2. Superior ao Centro } \\
\text { 3. Superior à Direita } \\
\text { 4. Centro à Esquerda } \\
\text { 5. Centro } \\
\text { 6. Centro à Direita } \\
\text { 7. Inferior à Esquerda } \\
\text { 8. Inferior ao centro } \\
\text { 9. Inferior à Direita }\end{array}$ & $\begin{array}{l}\text { 1. Se a mãe estiver em posição superior à esquerda em relação à família: está numa posição mais } \\
\text { passiva } \\
\text { 2. Se a mãe estiver numa posição superior ao centro em relação à família: está numa posição de } \\
\text { controle com busca de equilíbrio } \\
\text { 3. Se a mã̃e estiver em posição superior à direita em relação à família: está numa posição ativa } \\
\text { 4. Se a mãe estiver no centro à esquerda em relação à família: está numa posição de controle } \\
\text { passivo } \\
\text { 5. Se a mãe estiver no centro em relação à família: está numa posição de hipercontrole e busca de } \\
\text { equilíbrio } \\
\text { 6. Se a mãe estiver no centro à direita em relação à família: está numa posição ativa } \\
\text { 7. Se a mãe estiver em posição inferior à esquerda em relação à família: está uma posição passiva, } \\
\text { de submissão e desvalorizção } \\
\text { 8. Se a mãe estiver em posição inferior ao centro em relação à família: está numa posição de } \\
\text { submissão controlada } \\
\text { 9. Se a mãe estiver em posição inferior direita em relação à família: está numa posição de reação } \\
\text { à submissão (luta contra a submissão) }\end{array}$ \\
\hline $\begin{array}{l}\text { 22. Posição dos filhos (grupo familiar } \\
\text { eclodido) }\end{array}$ & $\begin{array}{l}\text { 1. Superior à Esquerda } \\
\text { 2. Superior ao Centro } \\
\text { 3. Superior à Direita } \\
\text { 4. Centro à Esquerda } \\
\text { 5. Centro } \\
\text { 6. Centro à Direita } \\
\text { 7. Inferior à Esquerda } \\
\text { 8. Inferior ao centro } \\
\text { 9. Inferior à Direita }\end{array}$ & $\begin{array}{l}\text { 1. Se a criança estiver em posição superior à esquerda em relação à família: está numa posição } \\
\text { mais passiva } \\
\text { 2. Se a criança estiver em posição superior ao centro em relação à família: está numa posição de } \\
\text { controle com busca de equilíbrio } \\
\text { 3. Se a criança estiver em posição superior à direita em relação à família: está numa posição ativa } \\
\text { 4. Se a criaça estiver no centro à esquerda em relação à família: está numa posição de controle } \\
\text { passivo } \\
\text { 5. Se a criança estiver no centro em relação à família: está numa posição de hipercontrole e busca } \\
\text { de equilíbrio } \\
\text { 6. Se a criança estiver no centro à direita em relação à família: está numa posição ativa }\end{array}$ \\
\hline
\end{tabular}




\begin{tabular}{|c|c|c|}
\hline & & $\begin{array}{l}\text { 7. Se a criança estiver numa posição inferior à esquerda em relação à família: está numa posição } \\
\text { passiva, de submissão e desvalorização } \\
\text { 8. Se a criança estiver em posição inferior ao centro em relação à família: está numa posição de } \\
\text { submissão controlada } \\
\text { 9. Se a criança estiver em posição inferior à direita em relação à família: está numa posição de } \\
\text { reação à submissão (luta contra a submissão) }\end{array}$ \\
\hline 23. Sentido de progressão da árvore & $\begin{array}{l}\text { 1. Horizontal da esquerda à direita } \\
\text { 2. Horizontal da direita à esquerda } \\
\text { 3. Vertical da parte superior à inferior } \\
\text { 4. Vertical da parte inferior à superior } \\
\text { 5. Circular da esquerda para a direita } \\
\text { 6. Circular da direita para a esquerda } \\
\text { 7. Irradiante } \\
\text { Circular: a progressão forma um } \\
\text { círculo que passa por um lado da } \\
\text { árvore e repassa pelo outro. } \\
\text { Irradiante: a progressão parte de um } \\
\text { ponto fixo e se afasta em todas as } \\
\text { direções. }\end{array}$ & $\begin{array}{l}\text { 1 e 2. A horizontalidade dá uma primeira amostra de confusão. Achata as relações de filiação, de } \\
\text { aliança e de transmissão intergeracional. Este modo de construção faz primar as relaços de } \\
\text { alianças e o aqui-e-agora. A horizontalidade favorece os fenómenos de deslocamento (dos papeis) } \\
\text { ou de metonímia. } \\
\text { 3. A verticalidade consiste em admitir a transmissão intergeracional, a presença das relações de } \\
\text { filiaçãa. Filhos/ancestrais na parte superior = heróis da família } \\
\text { 4. Filhos ou os antepassados na parte inferior = fontes de apoio, "carregam a família" } \\
5 \text { e } 6 \text {. O primeiro ramo que engrena o círculo é mais sólido ou mais importante. } \\
\text { 7. Há um ponto narcisista central da família com distanciamento das relações à periferia com } \\
\text { dispersão e mesmo dissociação, dinâmica centrífuga. }\end{array}$ \\
\hline 24. A progressão é alternada? & $\begin{array}{l}\text { Sim: A progressão é simétrica, em vai- } \\
\text { e-vem, de um ramo ao outro e } \\
\text { construída por solavancos. } \\
\text { Não: Construção de um ramo } \\
\text { integralmente seguido de outro. }\end{array}$ & Sim: Preocupação de igualdade entre os ramos e de valorização recíproca \\
\hline 25. Início da alternância pelo ramo & Materno/Paterno & $\begin{array}{l}\text { Se no ramo materno, é a dimensão simbiótica que conta. } \\
\text { Se no ramo paterno, o nome simbólico da família conta. }\end{array}$ \\
\hline 26. Tipo de sucessão & $\begin{array}{l}\text { 1. Ramo paterno para o ramo materno } \\
\text { 2. ramo materno para o ramo paterno }\end{array}$ & O ramo paterno/materno tem influência maior. \\
\hline 27. Desvio geracional & $\begin{array}{l}\text { Sim/Não } \\
\text { Erro na verticalidade da ordem lógica } \\
\text { das geracões. }\end{array}$ & $\begin{array}{l}\text { Sim: Confusão dos lugares e perturbações na temporalidade (problema de filiação). } \\
\text { Não: A diferença intergeracional é reconhecida }\end{array}$ \\
\hline 28. Onde o desvio é constatado & $\begin{array}{l}\text { 1. Filhos-Pais } \\
\text { 2. Filhos-Avós } \\
\text { 3. Filhos-Antepassados } \\
\text { 4. Filhos-Parentes } \\
\text { 5. Pais-Avós } \\
\text { 6. Pais-Antepassados } \\
\text { 7. Avós-Antepassados } \\
\text { 8. Parentes-Avós }\end{array}$ & $\begin{array}{l}\text { Maior ou menor graus de confusão conforme a distância entre gerações que é aproximada pelo } \\
\text { desvio. }\end{array}$ \\
\hline
\end{tabular}




\begin{tabular}{|c|c|c|}
\hline & 9. Parentes-Ancestrais & \\
\hline 29. Por qual familiar começa a árvore & $\begin{array}{l}\text { 1. Filho } \\
\text { 2. Pai } \\
\text { 3. Mãe } \\
\text { 4. Avós paternos } \\
\text { 5. Avós maternos } \\
\text { 6. Antepassados paternos } \\
\text { 7. Antepassados maternos } \\
\text { 8. Parentes paternos } \\
\text { 9. Parentes maternos } \\
\text { 10. Amigos } \\
\text { 11. Animais }\end{array}$ & $\begin{array}{l}\text { Os primeiros personagens terão um valor narcísico familiar de acordo com a sua ordem de } \\
\text { chegada. Se pessoas do exterior }=\text { recusa do sentimento familiar. }\end{array}$ \\
\hline 30. Em qual familiar termina a árvore & $\begin{array}{l}\text { 1. Filho } \\
\text { 2. Pai } \\
\text { 3. Mãe } \\
\text { 4. Avós paternos } \\
\text { 5. Avós maternos } \\
\text { 6. Antepassados paternos } \\
\text { 7. Antepassados maternos } \\
\text { 8. Parentes paternos } \\
\text { 9. Parentes maternos } \\
\text { 10. Amigos } \\
\text { 11. Animais }\end{array}$ & $\begin{array}{l}\text { Termina pela pessoa menos importante. É o elemento mais heterogêneo à família. } \\
\text { Se filho = rejeição ou problema de reconhecimento }\end{array}$ \\
\hline 31. Ordem de sucessão de gerações & $\begin{array}{l}\text { 1. Filhos-Pais-Avós-Antepassados } \\
\text { 2. Antepassados- Avós-Pais-Filhos } \\
\text { 3. Pais-Filhos-Avós } \\
\text { 4. Combinações diversas }\end{array}$ & $\begin{array}{l}\text { 1. As crianças representam uma base narcisista e uma razão de ser da família } \\
\text { 2. Os antepassados são a base narcisista da família. } \\
\text { Os antepassados são idealizados. Marca o peso e a importância da dívida para com os } \\
\text { antepassados. } \\
\text { 3. O objeto casal prima sobre o objeto família. O narcisismo é colocado mais sobre a } \\
\text { representatividade do casal. } \\
\text { 4. Interpretações caso a caso }\end{array}$ \\
\hline 32. Existe contiguidade temporal? & $\begin{array}{l}\text { Sim/Não } \\
\text { Contiguidade temporal: passagem de } \\
\text { um ramo a outro na cronologia da } \\
\text { construção. }\end{array}$ & $\begin{array}{l}\text { Sim: Associações de ideias em relação a certos membros das famílias de um ramo ao outro. } \\
\text { Alianças inconscientes comuns que ligam as pessoas. O transgeracional é evocado } \\
\text { Não: No caso em que há ausência total de uma linhagem familiar. }\end{array}$ \\
\hline 33. Número de contiguidades temporais & De 1 a 25 & $\begin{array}{l}\text { Quanto maior o número, mais alianças inconscientes entre as linhagens, exceto em construção } \\
\text { alternada. }\end{array}$ \\
\hline
\end{tabular}




\begin{tabular}{|c|c|c|}
\hline $\begin{array}{l}\text { 34. Localização da } 1^{\mathrm{a}} \text { contiguidade } \\
\text { temporal }\end{array}$ & & Associação de um ponto comum mais ou menos reprimido entre duas linhagens \\
\hline 35. Tipo de traçado das ligações & $\begin{array}{l}\text { 1. Um traço } \\
\text { 2. Dois traços } \\
\text { 3. Flecha } \\
\text { 4. Pontilhado } \\
\text { 5. Arco } \\
\text { 6. Traço código } \\
\text { 7. Sem ligação }\end{array}$ & $\begin{array}{l}\text { 1. Representa uma ligação } \\
\text { 2. Intensificação da relação } \\
\text { 3. Insistência da relação, agressividade } \\
\text { 4. Relação mal assumida } \\
\text { 5. Ideia de fusão } \\
\text { 6. Personalização simbólica da relação } \\
\text { 7. Ausência de relação ou problema de relação }\end{array}$ \\
\hline 36. Traços de ligação mais utilizados & $\begin{array}{l}\text { 1. Um traço } \\
\text { 2. Dois traços } \\
\text { 3. Flecha } \\
\text { 4. Pontilhado } \\
\text { 5. Arco } \\
\text { 6. Traço código } \\
\text { 7. Sem ligação }\end{array}$ & $\begin{array}{l}\text { 1. Forma da ligação = significado } \\
\text { 2. Intensificação da relação } \\
\text { 3. Insistência da relação = agressividade } \\
\text { 4. Relação mal assumida } \\
\text { 5. ideia de fusão } \\
\text { 6. Personalização simbólica da relação } \\
\text { 7. Ausência de relação ou clivagem, negação da relação }\end{array}$ \\
\hline $\begin{array}{l}\text { 37. Traçado ou zona vazia que separa a } \\
\text { árvore }\end{array}$ & Sim/Não & Sim: Sinal de clivagem. Oposição entre duas partes. \\
\hline 38. Formas que envolvem os personagens & $\begin{array}{l}\text { 1. Quadrado: forma com ângulos } \\
\text { 2. Redondo: toda forma circular } \\
\text { 3. Fluida: forma não geométrica } \\
\text { 4. Sem contorno: sem forma } \\
\text { verdadeira } \\
\text { 5. Símbolos e objetos variáveis }\end{array}$ & $\begin{array}{l}\text { 1. Pensamento sistemático, racional e conformista } \\
\text { 2. Sinal de oralidade Necessidade de um continente para pensamentos } \\
\text { 3. Problema de limite mal definido: indeterminação. Instabilidade. Falta de precisão } \\
\text { 4. Problema de limites. Falta de continência ou de identificação de forma. Não há busca de } \\
\text { proteção. } \\
\text { 5. Sinal do imaginário, simbólico e fantasmatização }\end{array}$ \\
\hline $\begin{array}{l}\text { 39. Ramo paterno em relação ao materno } \\
\text { - Posição }\end{array}$ & $\begin{array}{l}\text { 1. À esquerda na página } \\
\text { 2. À direita na página } \\
\text { 3. Acima } \\
\text { 4. Abaixo }\end{array}$ & $\begin{array}{l}\text { 1. Posição passiva } \\
\text { 2. Posição ativa } \\
\text { 3. Posição dominante } \\
\text { 4. Posição submissa }\end{array}$ \\
\hline $\begin{array}{l}\text { 40. Ramo paterno em relação ao materno } \\
\text { - Extensão }\end{array}$ & $\begin{array}{l}\text { 1. Mais extenso } \\
\text { 2. Igual } \\
\text { 3. Menos extenso }\end{array}$ & $\begin{array}{l}\text { 1. O ramo paterno é mais importante } \\
\text { 2. O ramo paterno é igualitário } \\
\text { 3. O ramo paterno é menos influente }\end{array}$ \\
\hline 41. Área vazia & Sim/Não & Sim: Área de negação ou de não investimento, repressão. \\
\hline 42. Local da área vazia & $\begin{array}{l}\text { 1. Filho } \\
\text { 2. Pai } \\
\text { 3. Mãe } \\
\text { 4. Avós paternos } \\
\text { 5. Avós maternos } \\
\text { 6. Ancestrais do lado paterno }\end{array}$ & \\
\hline
\end{tabular}




\begin{tabular}{|c|c|c|}
\hline & $\begin{array}{l}\text { 7. Ancestrais do lado materno } \\
\text { 8. Parentes do lado paterno } \\
\text { 9. Parentes do lado materno }\end{array}$ & \\
\hline 43. Área rasurada ou escurecida & Sim/Não & $\begin{array}{l}\text { Sim: Repressão, segredos, não dito. Provoca uma reação pelas rasuras e refere-se a diferentes } \\
\text { membros da família (pergunta 44). Sintoma de culpa se no aspecto neurótico. }\end{array}$ \\
\hline 44. Local da área rasurada ou escurecida & $\begin{array}{l}\text { 1. Filho } \\
\text { 2. Pai } \\
\text { 3. Mãe } \\
\text { 4. Avós paternos } \\
\text { 5. Avós maternos } \\
\text { 6. Ancestrais do lado paterno } \\
\text { 7. Ancestrais do lado materno } \\
\text { 8. Parentes do lado paterno } \\
\text { 9. Parentes do lado materno }\end{array}$ & \\
\hline 45. Área sobrecarregada de informação & Sim/Não & Sim: Sinal de um investimento dinâmico ou afetivo, melhor conhecimento. \\
\hline 46. Local da área sobrecarregada & $\begin{array}{l}\text { 1. Filho } \\
\text { 2. Pai } \\
\text { 3. Mãe } \\
\text { 4. Avós paternos } \\
\text { 5. Avós maternos } \\
\text { 6. Ancestrais do lado paterno } \\
\text { 7. Ancestrais do lado materno } \\
\text { 8. Parentes do lado paterno } \\
\text { 9. Parentes do lado materno }\end{array}$ & \\
\hline 47. Contiguidade espacial & Sim/Não & $\begin{array}{l}\text { Sim: Os dois ramos mostram uma ligação inconsciente entre as duas famílias. Ligações estreitas } \\
\text { ou ideia de confusão. O espaço representa as ligações inconscientes entre dois personagens. } \\
\text { Compreensão do desenho em sua configuração formal. Zonas que têm um fantasma inconsciente } \\
\text { em comum. } \\
\text { Em cada ramo (as pessoas que não deveriam estar lado a lado estão) }\end{array}$ \\
\hline 48. Local da contiguidade espacial & $\begin{array}{l}\text { 1. Filho } \\
\text { 2. Pai } \\
\text { 3. Mãe } \\
\text { 4. Avós paternos } \\
\text { 5. Avós maternos } \\
\text { 6. Ancestrais do lado paterno } \\
\text { 7. Ancestrais do lado materno } \\
\text { 8. Parentes do lado paterno } \\
\text { 9. Parentes do lado materno }\end{array}$ & \\
\hline
\end{tabular}




\begin{tabular}{|c|c|c|}
\hline 49. Zona densa de comentários & Sim/Não & $\begin{array}{l}\text { Sim: Sinal positivo de troca, de interfantasmatização, elemento dizível, negativo se são } \\
\text { comentários degradantes. Se adiciona mais do que a informação necessária = reação a um trauma, } \\
\text { mas capazes de falar um com o outro. } \\
\text { Não: Falta de comentários, árvore informativa }\end{array}$ \\
\hline 50. Local da zona densa de comentários & $\begin{array}{l}\text { 1. Filho } \\
\text { 2. Pai } \\
\text { 3. Mãe } \\
\text { 4. Avós paternos } \\
\text { 5. Avós maternos } \\
\text { 6. Ancestrais do lado paterno } \\
\text { 7. Ancestrais do lado materno } \\
\text { 8. Parentes do lado paterno } \\
\text { 9. Parentes do lado materno }\end{array}$ & \\
\hline 51. Zona de bloqueio & $\begin{array}{l}\text { Sim/Não } \\
\text { Áreas que causaram silêncio, um } \\
\text { bloqueio no ritmo de construção do } \\
\text { desenho. }\end{array}$ & $\begin{array}{l}\text { Sim: Choque, área de não dito ou de segredo familiar. Evento traumático. Aparecimento de ponto } \\
\text { de interrogação "lá eu não sei", a produção do discurso deixa de fluir ou se estanca. }\end{array}$ \\
\hline 52. Local da zona de bloqueio & $\begin{array}{l}\text { 1. Filho } \\
\text { 2. Pai } \\
\text { 3. Mãe } \\
\text { 4. Avós paternos } \\
\text { 5. Avós maternos } \\
\text { 6. Ancestrais do lado paterno } \\
\text { 7. Ancestrais do lado materno } \\
\text { 8. Parentes do lado paterno } \\
\text { 9. Parentes do lado materno } \\
\end{array}$ & \\
\hline 53. Zona de eventos marcantes & $\begin{array}{l}\text { Sim/Não } \\
\text { Discurso sobre evento traumático ou } \\
\text { não: morte, acidente, casamento, } \\
\text { nascimento, doença, viagem, } \\
\text { batismo... }\end{array}$ & $\begin{array}{l}\text { Sim: Abrange o intergeracional, a problemática familiar. Evoca a memória da família, promove } \\
\text { a ideologia familiar. }\end{array}$ \\
\hline 54. Local da zona de eventos marcantes & $\begin{array}{l}\text { 1. Filho } \\
\text { 2. Pai } \\
\text { 3. Mãe } \\
\text { 4. Avós paternos } \\
\text { 5. Avós maternos } \\
\text { 6. Ancestrais do lado paterno } \\
\text { 7. Ancestrais do lado materno } \\
\text { 8. Parentes do lado paterno }\end{array}$ & \\
\hline
\end{tabular}




\begin{tabular}{|c|c|c|}
\hline & 9. Parentes do lado materno & \\
\hline 55. Tipo de representação & $\begin{array}{l}\text { 1. Figurativo: artística com a presença } \\
\text { de raízes, ramos } \\
\text { 2. Geométrico: tipo tradicional de } \\
\text { genograma } \\
\text { 3. Misto: mistura de tipo figurativo e } \\
\text { geométrico } \\
\text { 4. Lista: a árvore é na verdade uma } \\
\text { lista de nomes ou pessoas }\end{array}$ & $\begin{array}{l}\text { 1. Figurativo: Predominância dos processos primários, o imaginário predomina. } \\
\text { 2. Geométrico: Pensamento racional, lógico, predominância de processos psíquicos secundários. } \\
\text { 3. Misto: Compromisso encontrado entre princípio do prazer e princípio da realidade, capacidade } \\
\text { de se mover flexivelmente dos processos secundários para os primários e vice-versa. } \\
\text { 4. Lista: Demonstra a falta de relações familiares potencialmente devido a traumas familiares. } \\
\text { Falta de coesão. Confusão de parentesco e diferença de geração. }\end{array}$ \\
\hline $\begin{array}{l}\text { 56. Números de estratos geracionais no } \\
\text { lado paterno }\end{array}$ & $\begin{array}{l}\text { 1. Uma geração } \\
\text { 2. Duas gerações } \\
\text { 3. Três gerações } \\
\text { 4. Quatro gerações } \\
\text { 5. Cinco gerações ou mais } \\
\text { 6. Nenhuma }\end{array}$ & $\begin{array}{l}\text { 1. Uma geração: Vivência no presente imediato, corte das raízes. } \\
\text { 2. Duas gerações: Relações intergeracionais normais. } \\
\text { 3. Três geraços: Relações intergeracionais sólidas } \\
\text { 4. Quatro gerações: Importância dos ancestrais } \\
\text { 5. Cinco gerações ou mais: Peso bloqueador do passado } \\
\text { 6. Nenhuma: Clivagem, negação, repressão }\end{array}$ \\
\hline $\begin{array}{l}\text { 57. Números de estratos geracionais no } \\
\text { lado materno }\end{array}$ & $\begin{array}{l}\text { 1. Uma geração } \\
\text { 2. Duas gerações } \\
\text { 3. Três gerações } \\
\text { 4. Quatro gerações } \\
\text { 5. Cinco gerações ou mais } \\
\text { 6. Nenhuma }\end{array}$ & $\begin{array}{l}\text { 1. Uma geração: Vivência no presente imediato, corte das raízes. } \\
\text { 2. Duas gerações: Relações intergeracionais normais. } \\
\text { 3. Três gerações: Relações intergeracionais sólidas } \\
\text { 4. Quatro gerações: Importância dos ancestrais } \\
\text { 5. Cinco geraçôs ou mais: Peso bloqueador do passado } \\
\text { 6. Nenhuma: Clivagem, negação, repressão }\end{array}$ \\
\hline $\begin{array}{l}\text { 58. Números de ramificações no lado } \\
\text { paterno }\end{array}$ & & $\begin{array}{l}\text { Mais ramificações = relações mais complexas. } \\
\text { Nenhuma diferença significativa entre os ramos materno e paterno }\end{array}$ \\
\hline $\begin{array}{l}\text { 59. Números de ramificações no lado } \\
\text { materno }\end{array}$ & & $\begin{array}{l}\text { Mais ramificações = relações mais complexas. } \\
\text { Nenhuma diferença significativa entre os ramos materno e paterno }\end{array}$ \\
\hline $\begin{array}{l}\text { 60. Número total de pessoas } \\
\text { representadas }\end{array}$ & & Pessoas simbolicamente presentes na família, mesmo que não sejam conhecidas. \\
\hline 61. Número total de pessoas conhecidas & & Memória objetiva, consciente, sinal de boa memória e controle da família. \\
\hline $\begin{array}{l}\text { 62. Número de pessoas integradas à } \\
\text { família por aliança }\end{array}$ & & $\begin{array}{l}\text { "Vínculo de aliança" sinal da capacidade da família para se abrir ao exterior + capacidade de } \\
\text { integração (enriquecer-se com o exterior), sinal de flexibilidade e normalidade. } \\
\text { Contrariamente = autarquia, narcisismo }\end{array}$ \\
\hline 63. Pertencimento cultural & Cidade/estado/país de origem & \\
\hline 64. Tipo de família & $\begin{array}{l}\text { 1. Família não separada } \\
\text { 2. Família separada recomposta }\end{array}$ & \\
\hline
\end{tabular}




\begin{tabular}{|c|c|c|}
\hline & $\begin{array}{l}\text { 3. Família separada não recomposta } \\
\text { 4. Família monoparental }\end{array}$ & \\
\hline 65. Pais presentes na aplicação & $\begin{array}{l}\text { 1. Somente o pai } \\
\text { 2. Somente a mãe } \\
\text { 3. Pai e mãe } \\
\text { 4. Nenhum }\end{array}$ & \\
\hline 66. Lugar da aplicação & $\begin{array}{l}\text { 1. Cozinha } \\
\text { 2. Sala de estar } \\
\text { 3. Sala de jantar } \\
\text { 4. Quarto } \\
\text { 5. Escritório } \\
\text { 6. Corredor } \\
\text { 7. Outro }\end{array}$ & \\
\hline $\begin{array}{l}\text { 67. Mudança de lugar no curso da } \\
\text { aplicação }\end{array}$ & Sim/Não & Sim: pode ser um sinal de instabilidade, a analisar, situação excepcional. \\
\hline 68. Animais vivem com a família & Sim/Não & $\begin{array}{l}\text { Sim: em conexão com a questão 83, os animais são representados no desenho? } \\
\text { Dimensão emocional compensatória, parte reprimida da família. }\end{array}$ \\
\hline 69. Duração da aplicação em minutos & $\begin{array}{l}\text { Média: } 43,7 \mathrm{~min} \\
\text { Entre } 20 \text { e } 60 \mathrm{~min}: \text { normal }\end{array}$ & $\begin{array}{l}\text { Tempo rápido: resistência ao teste. Problema de auto-representação, defensivo, operatório. } \\
\text { Tempo longo: lado obsessivo, ideia de não esquecer ninguém. } \\
\text { Tempo muito longo: ideia de dívida, vínculo de lealdade, existência de culpa em caso de } \\
\text { esquecimento. }\end{array}$ \\
\hline 70. Profissão do pai & $\begin{array}{l}\text { 1. Sem atividade } \\
\text { 2. Operário } \\
\text { 3. Empregado } \\
\text { 4. Média gerência } \\
\text { 5. Gerência sênior } \\
\text { 6. Agricultor } \\
\text { 7. Artesão } \\
\text { 8. Profissional liberal } \\
\text { 9. Aposentado }\end{array}$ & \\
\hline 71. Profissão da mãe & $\begin{array}{l}\text { 1. Sem atividade } \\
\text { 2. Operário } \\
\text { 3. Empregada } \\
\text { 4. Média gerência } \\
\text { 5. Gerência sênior } \\
\text { 6. Agricultora } \\
\text { 7. Artesã } \\
\text { 8. Profissional liberal } \\
\text { 9. Aposentada }\end{array}$ & \\
\hline
\end{tabular}




\begin{tabular}{|c|c|c|}
\hline 72. Quem desenha a árvore & $\begin{array}{l}\text { 1. Pai } \\
\text { 2. Mãe } \\
\text { 3. Filho } \\
\text { 4. Ancestral } \\
\text { 5. Avós } \\
\text { 6. Parentes }\end{array}$ & $\begin{array}{l}\text { Interessante conhecer o lugar ocupado pela criança e pelos idosos na família. } \\
\text { Quem desenha: tem um papel condutor, assume o que sabe e se impõe, força motriz. } \\
\text { Se é o filho: parentificação. }\end{array}$ \\
\hline \multicolumn{3}{|l|}{$\begin{array}{l}\text { 73. Se é uma criança, qual é sua } \\
\text { classificação nos irmãos }\end{array}$} \\
\hline 74. Se é uma criança, qual é seu sexo & $\mathrm{M} / \mathrm{F}$ & \\
\hline 75. Quem dirige o desenho & $\begin{array}{l}\text { 1. Pai } \\
\text { 2. Mãe } \\
\text { 3. Filho } \\
\text { 4. Ancestral } \\
\text { 5. Avós } \\
\text { 6. Parentes }\end{array}$ & Função de autoridade, de poder fálico. \\
\hline \multicolumn{3}{|l|}{$\begin{array}{l}\text { 76. Se é uma criança, qual é sua } \\
\text { classificação nos irmãos }\end{array}$} \\
\hline 77. Se é uma criança, qual é seu sexo & $\mathrm{M} / \mathrm{F}$ & \\
\hline 78. Alguém comenta sobre o desenho & Sim/Não & \\
\hline 79. Quem comenta & $\begin{array}{l}\text { 1. Pai } \\
\text { 2. Mãe } \\
\text { 3. Filho } \\
\text { 4. Ancestral } \\
\text { 5. Avós } \\
\text { 6. Parentes }\end{array}$ & $\begin{array}{l}\text { Posição de crítica ou justificativa. Coloca-se como superego: Poder de desqualificação ou } \\
\text { valorização, de acordo com a natureza das observações. }\end{array}$ \\
\hline \multicolumn{3}{|l|}{$\begin{array}{l}\text { 80. Se é uma criança, qual é sua } \\
\text { classificação nos irmãos }\end{array}$} \\
\hline 81. Se é uma criança, qual é seu sexo & $\mathrm{M} / \mathrm{F}$ & \\
\hline 82. Tipo de comentários & $\begin{array}{l}\text { 1. Ansiosos } \\
\text { 2. Desvalorizadores } \\
\text { 3. Moderadores } \\
\text { 4. Valorizadores }\end{array}$ & $\begin{array}{l}\text { Ansiosos: busca por se fazer compreender, falta de autoconfiança, medo de julgamento. } \\
\text { Desvalorizadores: autodestrutivo, autodepreciativo, sentimento de fracasso, autopunitivo. } \\
\text { Moderadores: procura de compromisso, soluções e suporte. } \\
\text { Valorizadores: otimismo, ideal narcisista, grandiosidade }\end{array}$ \\
\hline 83. Animais presentes no desenho & Sim/Não & $\begin{array}{l}\text { Sim: Necessidade de representar o animal, ele faz parte da família. Um elemento reprimido } \\
\text { pertencente à família, o animal representa as partes imaturas da família. Um duplo narcisista, } \\
\text { serve para curar as deficiências emocionais, compensar pelos seres ausentes na família. }\end{array}$ \\
\hline
\end{tabular}


ANEXO L - Guia de cotação e interpretação da Espaciografia Projetiva Familiar

\begin{tabular}{|c|c|c|}
\hline Item & Possibilidades e Significado descritivo & Interpretações \\
\hline \multicolumn{3}{|l|}{ 1. Identificação do protocolo } \\
\hline 2. Existe uma planta interior & Sim/Não & \\
\hline 3. Tipo de família & $\begin{array}{l}\text { 1. Família não separada } \\
\text { 2. Família separada recomposta } \\
\text { 3. Família nuclear estendida (por um } \\
\text { parente ou incluindo um dos avós.) } \\
\text { 4. Família monoparental } \\
\text { 5. Família homoparental }\end{array}$ & \\
\hline $\begin{array}{l}\text { 4. Composição da família que vive } \\
\text { sob o mesmo teto }\end{array}$ & $\begin{array}{l}\text { 1. Pais } \\
\text { 2. Sogros } \\
\text { 3. Filhos } \\
\text { 4. Parentes } \\
\text { 5. Avós }\end{array}$ & \\
\hline \multicolumn{3}{|l|}{ 5. Número de filhos na família } \\
\hline $\begin{array}{l}\text { 6. Especificar a idade do ou dos } \\
\text { filhos }\end{array}$ & $\begin{array}{l}\text { 1. } 3 \text { anos ou menos } \\
\text { 2. De } 3 \text { a } 5 \text { anos } \\
\text { 3. De } 6 \text { a } 12 \text { anos } \\
\text { 4. Mais de } 12 \text { anos } \\
\end{array}$ & \\
\hline 7. Especifique o parentesco & $\begin{array}{l}\text { 1. Tio } \\
\text { 2. Tia } \\
\text { 3. Primo(a) } \\
\text { 4. Sobrinho } \\
\text { 5. Sobrinha } \\
\text { 6. Outros }\end{array}$ & \\
\hline 8. Participantes no experimento & $\begin{array}{l}\text { 1. Pai } \\
\text { 2. Mãe } \\
\text { 3. Sogros } \\
\text { 4. Filhos } \\
\text { 5. Parentes } \\
\text { 6. Avô } \\
\text { 7. Avó }\end{array}$ & \\
\hline $\begin{array}{lr}\text { 9. Especifique a idade } & \text { da(s) } \\
\text { criança(s) participante(s) } & \text { no } \\
\text { experimento } & \\
\end{array}$ & $\begin{array}{l}\text { 1. } 3 \text { anos ou menos } \\
\text { 2. De } 3 \text { a } 5 \text { anos } \\
\text { 3. De } 6 \text { a } 12 \text { anos } \\
\end{array}$ & \\
\hline
\end{tabular}




\begin{tabular}{|c|c|c|}
\hline & 4. Mais de 12 anos & \\
\hline $\begin{array}{l}\text { 10. Especificar quais parentes } \\
\text { participam do experimento }\end{array}$ & $\begin{array}{l}\text { 1. Tio } \\
\text { 2. Tia } \\
\text { 3. Primo (a) } \\
\text { 4. Sobrinho } \\
\text { 5. Sobrinha } \\
\text { 6. Outros }\end{array}$ & \\
\hline 11. Tipo de habitação & $\begin{array}{l}\text { 1. Apartamento } \\
\text { 2. Casa } \\
\text { 3. Outro }\end{array}$ & \\
\hline $\begin{array}{l}\text { 12. Se } \\
\text { especifique: }\end{array}$ & & \\
\hline 13. Idade do alojamento & $\begin{array}{l}\text { 1. Novo } \\
\text { 2. Antigo }\end{array}$ & $\begin{array}{l}\text { 1. Ligado a uma fantasia narcisista de auto-construção, auto-engendramento, vivendo no aqui e agora } \\
\text { 2. Necessidade de apoio no passado }\end{array}$ \\
\hline 14. Estilo de mobiliário & $\begin{array}{l}\text { 1. Antigo } \\
\text { 2. Móveis de família } \\
\text { 3. Misto } \\
\text { 4. Moderno }\end{array}$ & $\begin{array}{l}\text { O tipo de mobiliário evoca a parte interna do envelope familiar. } \\
\text { 1. Evoca valores conformistas, com necessidade de segurança } \\
\text { 2. Evoca o vínculo e a herança direta dos antepassados (memória familiar) } \\
\text { 4. Desejo de cortar-se do passado, ao extremo, fazer como "tábula rasa" }\end{array}$ \\
\hline $\begin{array}{l}\text { 15. Categoria socioprofissional da } \\
\text { mãe }\end{array}$ & $\begin{array}{l}\text { 1. Agricultor } \\
\text { 2. Comerciante, Artesão, Chefe de } \\
\text { Empresa } \\
\text { 3. Quadro. Profissão Intelectual Superior } \\
\text { 4. Profissão Intermediária } \\
\text { 5. Empregado } \\
\text { 6. Trabalhador } \\
\text { 7. Desempregado } \\
\text { 8. Estudante } \\
\text { 9. Inativo } \\
\text { 10. Outro }\end{array}$ & \\
\hline $\begin{array}{l}\text { 16. Categoria socioprofissional do } \\
\text { pai }\end{array}$ & $\begin{array}{l}\text { 1. Agricultor } \\
\text { 2. Comerciante, Artesão, Chefe de } \\
\text { Empresa } \\
\text { 3. Quadro. Profissão Intelectual Superior } \\
\text { 4. Profissão Intermediária } \\
\text { 5. Empregado } \\
\text { 6. Trabalhador } \\
\text { 7. Desempregado } \\
\text { 8. Estudante } \\
\text { 9. Inativo } \\
\end{array}$ & \\
\hline
\end{tabular}




\begin{tabular}{|c|c|c|}
\hline & 10. Outro & \\
\hline \multicolumn{3}{|l|}{ 17. Origens familiares } \\
\hline 18. A família é: & $\begin{array}{l}\text { 1. Proprietária } \\
\text { 2. Locatária }\end{array}$ & $\begin{array}{l}\text { 1. Aquisição de um envelope, apoio sobre o envelope } \\
\text { 2. Envelope flutuante }\end{array}$ \\
\hline 19. Lugar do experimento & $\begin{array}{l}\text { 1. Sala de jantar } \\
\text { 2. Sala de estar } \\
\text { 3. Cozinha } \\
\text { 4. Quarto de dormir } \\
\text { 5. Quarto do filho } \\
\text { 6. Outro }\end{array}$ & $\begin{array}{l}\text { Dependendo da localização, isso nos diz sobre o grau de permeabilidade do envelope familiar, a } \\
\text { capacidade da família para se expor ao exterior ou não, seu nível defensivo: } \\
\text { 1. A sala de jantar, lugar oficial onde somos estamos mais representados. } \\
\text { 2. A sala de estar: oferece uma imagem de representação oficial, mas é um lugar mais caloroso que a } \\
\text { sala de jantar. O nível defensivo da família é flexível. } \\
\text { 3. A cozinha é um lugar mais amigável (local de oralidade) que mostra um nível defensivo bastante } \\
\text { baixo na família. } \\
\text { 4. O quarto é um lugar muito íntimo e reservado para alguns membros da família autorizados a entrar. }\end{array}$ \\
\hline \multicolumn{3}{|l|}{ 20. Se outro, especifique: } \\
\hline $\begin{array}{l}\text { 21. Duração de execução da } \\
\text { planta-baixa (em minutos) }\end{array}$ & & Quanto menor o tempo, mais defensiva está a família, menos investida na tarefa. \\
\hline 22. Sucesso na & $\begin{array}{l}\text { 1. Primeira tentativa } \\
\text { 2. Segunda tentativa }\end{array}$ & $\begin{array}{l}\text { 1. Capacidade de trabalhar em conjunto. } \\
\text { 2. Riscado: Ação falha é assumida pela família, tipo de defesa neurótica: denegação. } \\
\text { Devolução: Ação falha não é assumida, defesa do tipo negação, dificuldade na representação de si. }\end{array}$ \\
\hline 23. Quem desenha & $\begin{array}{l}\text { 1. Pai } \\
\text { 2. Mãe } \\
\text { 3. Filho } \\
\text { 4. Outro (sogro, sogra) }\end{array}$ & Dependendo da pessoa, isso indica quem assume o papel de porta-voz ou líder na família. \\
\hline $\begin{array}{l}\text { 24. Se outra pessoa que desenha } \\
\text { num segundo momento, } \\
\text { especifique }\end{array}$ & & $\begin{array}{l}\text { Quem traz uma função de suporte, de alívio, "a boa palavra". Precisa demonstrar sua utilidade na } \\
\text { família. Ou uma maneira de desqualificar o outro, necessidade de controle ou proteção do pacto } \\
\text { denegativo familiar (Kaës, Ruffiot) }\end{array}$ \\
\hline 25. Quem mais desenha? & $\begin{array}{l}\text { 1. Pai } \\
\text { 2. Mãe } \\
\text { 3. Filho } \\
\text { 4. Outro }\end{array}$ & Indica um grau de envolvimento familiar, pessoa que assume um papel de porta-voz dentro da família. \\
\hline $\begin{array}{l}\text { 26. Se é um dos filhos quem mais } \\
\text { desenha, especifique o sexo }\end{array}$ & $\begin{array}{l}\text { 1. M } \\
\text { 2. F }\end{array}$ & $\begin{array}{l}\text { A criança representa a parte inconsciente dos pais (comissionada), ou é atribuída à criança um papel e } \\
\text { um lugar (por exemplo, criança parentificada, inversão geracional). } \\
\text { Primazia do gênero masculino ou feminino. }\end{array}$ \\
\hline $\begin{array}{l}\text { 27. Se é uma criança que desenha } \\
\text { mais, qual é seu lugar dentre os } \\
\text { irmãos }\end{array}$ & & $\begin{array}{l}\text { A ordem dos lugares está ou não em correlação com a implicação? O filho mais velho tem um papel } \\
\text { de porta-voz? } \\
\text { Se o caçula substitui o mais velho: inversão dos estatutos. }\end{array}$ \\
\hline 28. Quem dirige & $\begin{array}{l}\text { 1. Pai } \\
\text { 2. Mãe } \\
\text { 3. Filho }\end{array}$ & $\begin{array}{l}\text { A pessoa que dirige é aquela que tem um papel dinâmico, motor, de autoridade ou dominante na } \\
\text { família. Quando é criança: há parentificação (inversão de geraçoses). }\end{array}$ \\
\hline
\end{tabular}




\begin{tabular}{|c|c|c|}
\hline & 4. Outro & \\
\hline \multicolumn{3}{|l|}{$\begin{array}{l}\text { 29. Se outro que dirige, } \\
\text { especifique }\end{array}$} \\
\hline $\begin{array}{l}\text { 30. Se é um dos filhos que dirige, } \\
\text { especifique o sexo }\end{array}$ & $\begin{array}{l}\text { 1. M } \\
\text { 2. } \mathrm{F}\end{array}$ & \\
\hline $\begin{array}{l}\text { 31. Se é um dos filhos que dirige, } \\
\text { qual é seu lugar dentre os irmãos }\end{array}$ & & $\begin{array}{l}\text { É interessante conhecer o lugar ocupado pela criança na família, a ordem dos lugares é respeitada ou } \\
\text { não? Se o mais novo ocupa o lugar do mais velho: inversão dos estatutos. }\end{array}$ \\
\hline 32. Quem comenta mais & $\begin{array}{l}\text { 1. Pai } \\
\text { 2. Mãe } \\
\text { 3. Filho } \\
\text { 4. Outro }\end{array}$ & $\begin{array}{l}\text { A pessoa que comenta tem uma posição de crítica, de julgamento moral, que cumpre uma função de } \\
\text { superego familiar. Pode ter uma função de suporte do vínculo (comentário de apoio, re-narcisante, } \\
\text { como uma função de proibição, rígida, desqualificadora. } \\
\text { A natureza da intervenção do comentarista (julgamento benevolente ou negativo) pode ser indicativa } \\
\text { do respeito ou não do pacto denegativo da família pela pessoa que desenhou. } \\
\text { Comentários positivos ou negativos também são um indicador do nível de ilusão grupal. }\end{array}$ \\
\hline \multicolumn{3}{|l|}{$\begin{array}{l}\text { 33. Se é outro que comenta mais, } \\
\text { especifique }\end{array}$} \\
\hline $\begin{array}{l}\text { 34. Se é um dos filhos que mais } \\
\text { comenta, especifique o sexo }\end{array}$ & $\begin{array}{l}\text { 1. } \mathrm{M} \\
\text { 2. } \mathrm{F}\end{array}$ & \\
\hline \multicolumn{3}{|l|}{$\begin{array}{l}\text { 35. Se é um dos filhos que mais } \\
\text { comenta, especifique seu lugar } \\
\text { dentre os irmãos }\end{array}$} \\
\hline 36. Posição da folha & $\begin{array}{l}\text { 1. Vertical } \\
\text { 2. Horizontal }\end{array}$ & $\begin{array}{l}\text { 1. Sinal de conformismo. } \\
\text { 2. Necessidade de dominar a tarefa alterando o que foi solicitado de antemão. Reação de oposição à } \\
\text { instrução, quer por causa de um pânico ou para se colocar contra o examinador. Movimento } \\
\text { ansiogênico. Falta de segurança interna. } \\
\text { - Cf. "devolução" no Rorschach ou teste da árvore (Stora) }\end{array}$ \\
\hline $\begin{array}{l}37 . \text { Posição geral da } \\
\text { gráfica na página } \\
\text { gração } \\
\text { decorações incluídas) }\end{array}$ & $\begin{array}{l}\text { 1. Esquerda Superior } \\
\text { 2. Esquerda ao Centro } \\
\text { 3. Superior à Direita } \\
\text { 4. Centro à Esquerda } \\
\text { 5. Centro } \\
\text { 6. Centro à Direita } \\
\text { 7. Inferior à Esquerda } \\
\text { 8. Inferior ao Centro } \\
\text { 9. Inferior à Direita }\end{array}$ & $\begin{array}{l}\text { 1. Luta antidepressiva pela excitação. Retração, ansiedade, defesa reacional. Necessidade de apoio no } \\
\text { passado. } \\
\text { 2. Superior: luta antidepressiva pela excitação. } \\
\text { Centro: sistematismo, necessidade de segurança, ansiedade, insegurança emocional, organização, } \\
\text { busca de autocontrole. } \\
\text { 3. Superior: Luta antidepressiva por excitação } \\
\text { Direita: Necessidade de movimento, agir do lado do futuro (instabilidade e busca por autocontrole) } \\
\text { Noção de ação (ambição, desejo de comandar, impor-se aos outros) } \\
\text { 4. Centro: Conformidade, controle, luta contra uma certa insegurança, sistematismo } \\
\text { Esquerda: peso do passado. } \\
\text { 5. Sinal de conformidade e controle. Sistematização, ansiedade: pode ser reativo à insegurança } \\
\text { emocional. } \\
\text { 6. Família que vai para o lado da ação e o futuro. }\end{array}$ \\
\hline
\end{tabular}




\begin{tabular}{|c|c|c|}
\hline & & $\begin{array}{l}\text { 7. Sinal de depressão e necessidade de escoramento. Ambivalência com a mãe e ausência do pai. } \\
\text { Ansiedade. } \\
\text { 8. Sinal de depressão, insegurança emocional e necessidade de escorar. Sinal de conformidade e } \\
\text { controle. Submissão. } \\
\text { 9. Inferior: impressão de não-valor, insuficiência, impressão de abandono. Sinal de depressão e } \\
\text { necessidade de suporte. Busca de apoio em uma imagem ou função paterna. }\end{array}$ \\
\hline $\begin{array}{l}\text { 38. Superfície ocupada pelo } \\
\text { desenho (casa e decorações } \\
\text { incluídas) } \\
\text { Permite estudar especialmente o } \\
\text { nível de segurança interna da } \\
\text { família e informa sobre seu grau } \\
\text { defensivo. }\end{array}$ & $\begin{array}{l}\text { 1. Menos de } 1 / 4 \text { da página } \\
\text { Família em contração } \\
\text { 2. Padrão } \\
\text { 3. Toda a folha } \\
\text { Família em expansão }\end{array}$ & $\begin{array}{l}\text { 1. Corpo aglutinado, família em contração ou retração para garantir sua segurança. Inibição } \\
\text { Vontade de se esconder, defesa, sinal de insegurança. Não-expressão de si. Fragilidade narcísica. } \\
\text { 2. Normalidade } \\
\text { 3. Família em expansão. Família que se mostra extrovertida, otimista, que se espalha, família } \\
\text { transbordante, exuberante. }\end{array}$ \\
\hline $\begin{array}{l}\text { 39. Área ocupada somente pela } \\
\text { casa }\end{array}$ & $\begin{array}{l}\text { 1. Menos de } 1 / 4 \text { da página } \\
\text { 2. Padrão: desenho que ocupa uma } \\
\text { superfície entre } 1 / 4 \mathrm{e}^{3 / 4} \text { da folha } \\
\text { 3. Folha inteira: desenho de } 3 / 4 \text { ou mais da } \\
\text { superfície da folha }\end{array}$ & $\begin{array}{l}\text { 1. Inibição. Pobreza imaginária. Deficiência na segurança interna. Corpo aglutinado, família em } \\
\text { contração ou retração para garantir sua segurança. } \\
\text { 2. Normalidade } \\
\text { 3. Expansão. Dimensão egocêntrica, narcísica, foco no eu-familiar. }\end{array}$ \\
\hline $\begin{array}{l}\text { 40. A folha foi usada em frente e } \\
\text { verso para representar várias } \\
\text { partes ou pavimentos da casa }\end{array}$ & Sim/Não & $\begin{array}{l}\text { Sim: Necessidade de expressar o eu-familiar usando todas as possibilidades e mostrando todos os } \\
\text { aspectos da casa. Necessidade de lugar: expansão egocêntrica (auto narcisista) ou inclinação obsessiva } \\
\text { (necessidade de explicar, justificar pela adição de elementos da casa). }\end{array}$ \\
\hline $\begin{array}{l}\text { 41. As bordas da folha constituem } \\
\text { os limites da planta interna }\end{array}$ & Sim/Não & $\begin{array}{l}\text { Sim: Família que não possui seus próprios limites, é a folha que os impõe (objeto externo). Busca por } \\
\text { apoio no objeto folha, sinal de operação anaclítica. Para a família cujo desenho toca a borda da folha: } \\
\text { desrespeito aos limites. } \\
\text { Não: Controle mais operante, a família concede seu próprio enquadre sem buscar a folha como suporte. } \\
\text { Capacidade de auto-escoramento. }\end{array}$ \\
\hline 42. Tipo de traço mais frequente & $\begin{array}{l}\text { 1. Traço simples } \\
\text { 2. Traços duplos } \\
\text { 3. Traços pontilhadas } \\
\text { 4. Traços sombreados } \\
\text { 5. Traços rasurados } \\
\text { 6. Área escurecida } \\
\text { 7. Traço contínuo que contorna o } \\
\text { conjunto } \\
\text { 8. Traços diversos }\end{array}$ & $\begin{array}{l}\text { O traço é o que conecta e separa. Traço em termos de limite, de vínculo e barreira de para-excitação. } \\
\text { 1. Normalidade } \\
\text { 2. Traduz a necessidade de fortalecer os limites do envelope familiar (defesas rígidas). Reforço das } \\
\text { defesas para assegurar o envelope familiar ligado a um ego frágill. } \\
\text { 3. Zonas porosas, sinal de quebra e fragilidade do envelope familiar. } \\
\text { 4. Defesas paradoxais: zonas abertas e fechadas ao mesmo tempo. Sinal de inquietação e agressividade. } \\
\text { Noções de esconder, coçar, entrincheirar e proteger. Para-excitação descontínua que não cumpre } \\
\text { plenamente sua função de proteção. } \\
\text { 5. Equivalente a lapso ou erro. Os atos falhos da família são postos em evidência. } \\
\text { 6. Angústia, descarga de afetos. Não-ditos, segredos. Desejo de revelação barrado por mecanismos de } \\
\text { repressão da culpa. } \\
\text { 7. Bons limites. Traduz um envelope familiar sólido, boa continência do self familiar, com uma } \\
\text { adequação das defesas relacionadas à para-excitação. }\end{array}$ \\
\hline
\end{tabular}




\begin{tabular}{|c|c|c|}
\hline & & $\begin{array}{l}\text { 8. Sinal de variações de defesas que podem entrar em extremos, flutuações. } \\
\text { Significado negativo: envelope familiar instável } \\
\text { Significado Positivo: riqueza do envelope familiar }\end{array}$ \\
\hline $\begin{array}{l}\text { 43. Existem traços específicos } \\
\text { para cômodos internos? }\end{array}$ & Sim/Não & $\begin{array}{l}\text { Sim: Para ser analisado de acordo com o simbolismo do lugar. } \\
\text { Cozinha: relacionada à oralidade } \\
\text { Sala de jantar: local oficial de representação da família (imagem narcisista) } \\
\text { Sala de estar: um lugar intermediário para representação e convivência } \\
\text { Quarto dos pais: Lugar de Sexualidade "Permitido" } \\
\text { Quarto das crianças: lugar regressivo e intimista } \\
\text { Quarto de brinquedos: lugar regressivo, brincalhão, imaginário } \\
\text { Quarto de hóspedes: lugar da recepção da ligação com o exterior } \\
\text { Banheiro: intimidade do corpo, analidade } \\
\text { Sala de múltiplas funções: local de transição, lugar não local } \\
\text { Escritório: lugar intelectual } \\
\text { Porão: lugar de repressão, conotação do corpo relacionada às funções do corpo arcaico } \\
\text { Sótão: lugar de memória } \\
\text { Varanda: lugar paradoxal (dentro e fora ao mesmo tempo) } \\
\text { Ateliê: local de conserto, do "fazer", analidade } \\
\text { Garagem: lugar em conexão com o exterior } \\
\text { Quarto anônimo: lugar de indiferenciação, lugar impensável } \\
\text { Outro: corredor, hall: lugar não lugar, (lugar de "inter-dição") }\end{array}$ \\
\hline 44. Quais? & & Interpretar de acordo com o simbolismo \\
\hline 45. Se sim a 43: quais cômodos? & & Para ser interpretado de acordo com o lugar \\
\hline 46. Forma geral & $\begin{array}{l}\text { 1. Quadrada } \\
\text { 2. Oval } \\
\text { 3. Mista } \\
\text { 4. Indeterminada }\end{array}$ & $\begin{array}{l}\text { 1. De um ponto de vista positivo: envelope familiar continente e estruturado. } \\
\text { De um ponto de vista negativo: pode indicar uma falta de imaginário familiar. Rigidez das defesas } \\
\text { 2. Regressivo, refere-se ao continente materno. Originalidade. Pode referir-se a uma especificidade } \\
\text { cultural. } \\
\text { Repressão da agressividade. } \\
\text { 3. Flexibilidade psíquica alternando estrutura masculina (quadrada, triangular) e estrutura feminina } \\
\text { (oval). } \\
\text { 4. Positivo: imaginário rico, interfantasmatização. } \\
\text { Negativo: eclosão, fragmentação, insegurança, desintegração interna da família. Revela falta de } \\
\text { continência do envelope familiar. }\end{array}$ \\
\hline 47. Tipo de casa & $\begin{array}{l}\text { 1. Realista } \\
\text { 2. Artística } \\
\text { 3. Fantástica }\end{array}$ & $\begin{array}{l}\text { 1. Imaginação empobrecida. Pensamento operacional. Resistência à instrução. } \\
\text { 2. Imaginação rica, mas sem perder o sentido da realidade. } \\
\text { 3. A pulsionalidade domina a realidade, a dominação da fantasia que deforma a estrutura clássica do } \\
\text { envelope. }\end{array}$ \\
\hline 48. Estrutura da casa & $\begin{array}{l}\text { 1. Compacta: o desenho da casa forma um } \\
\text { bloco unificado. }\end{array}$ & 1. Imagem do corpo familiar unitário, a estrutura mais comum. Envelope familiar continente. \\
\hline
\end{tabular}




\begin{tabular}{|c|c|c|}
\hline & $\begin{array}{l}\text { 2. Aglomerada: a casa é construída por } \\
\text { sucessivas adições de partes colocadas } \\
\text { lado a lado. Processo de construção de } \\
\text { uma unidade pela adição de matéria, mas } \\
\text { dando uma sensação de consistência pela } \\
\text { massa aglutinada. } \\
\text { 3. Fragmentada: várias partes espalhadas } \\
\text { na folha sem ligação entre elas. }\end{array}$ & $\begin{array}{l}\text { 2. Falha na continência compensada por uma relação adesiva dos sucessivos envelopes familiares. } \\
\text { Início de percepção de uma massa para uma possível unidade primordial (elementos sincréticos). } \\
\text { 3. Imagem do corpo explodido, dinâmica de dispersão ou partição. Ausência de continência do } \\
\text { envelope familiar. }\end{array}$ \\
\hline 49. Tipo de representação & $\begin{array}{l}\text { 1. Planta 2D } \\
\text { 2. Planta 3D } \\
\text { 3. Representação exterior (fachada) } \\
\text { 4. Transparência (Interior visto pela } \\
\text { transparência) }\end{array}$ & $\begin{array}{l}\text { 1. Tipo mais comum de representação. (Nossa imaginação funciona em 2D.) } \\
\text { 2. Busca estética, artística, mas na maioria das vezes trata-se de desenhar de casa externa, sem acesso } \\
\text { à interioridade. Evoca a nossa realidade. Implica a profundidade de campo. } \\
\text { Intuição de uma interioridade (a noção de continência é expressa). } \\
\text { 3. Dificuldade de acesso à interioridade da família, tipo de defesas em falso-self (primazia da aparência } \\
\text { ou superficialidade) } \\
\text { 4. Confusão entre o interior e o exterior. } \\
\text { Para-excitação falha não protege a intimidade psíquica. } \\
\text { Destaca o impulso escópico (voyeurismo, exibicionismo) } \\
\text { Evidência do corpo, infantilidade e imaturidade. }\end{array}$ \\
\hline 50. Número de andares & & $\begin{array}{l}\text { Representação antropomórfica do corpo do edifício. Andares elevados marcam a presença da psique } \\
\text { elaborada. O piso térreo evoca o corporal. } \\
\text { - Pavimento sob o teto: instâncias psíquicas dominantes, lugar de memória, reflexões ou ordem } \\
\text { - } 1^{\circ} \text { andar: o eu corporal da família, local de vida } \\
\text { Porão: fundação inconsciente da personalidade, ancoragem nas funções somáticas do corpo. } \\
\text { De baixo para cima: do menos controlado para o mais controlado. }\end{array}$ \\
\hline 51. Presença de cômodos idênticos & Sim/Não & $\begin{array}{l}\text { Sim: não há diferenciação. Estereotipias, corpo comum: pólo isomórfico predominante. } \\
\text { Não: boa capacidade de diferenciação: pólo homomórfico predominante. }\end{array}$ \\
\hline \multicolumn{3}{|l|}{ 52. Quais cômodos? } \\
\hline \multicolumn{3}{|l|}{$\begin{array}{l}\text { 53. Se há outros cômodos } \\
\text { idênticos, especifique }\end{array}$} \\
\hline $\begin{array}{l}\text { 54. Em que esses cômodos são } \\
\text { idênticos? }\end{array}$ & $\begin{array}{l}\text { 1. Uso } \\
\text { 2. Forma } \\
\text { 3. Superfície } \\
\text { 4. Mobiliário }\end{array}$ & $\begin{array}{l}\text { Qualifica a indiferenciação } \\
\text { A superfície e a forma serão sinais do nível arcaico de isomorfismo, enquanto o uso e o mobiliário são } \\
\text { formas mais elaboradas, mais próximas do nível de consciência. } \\
\text { Forma e superfície: âmbito do continente } \\
\text { Uso e mobília: âmbito do conteúdo }\end{array}$ \\
\hline 55. Processo de construção & $\begin{array}{l}\text { 1. Centrípeta } \\
\text { 2. Centrífuga }\end{array}$ & $\begin{array}{l}\text { 1. Habilidade de auto-continência da família, envelope familiar sólido, a menos que o quadro toque as } \\
\text { bordas da folha (ver item 41). A família tem naturalmente a necessidade de dispor um enquadre que } \\
\text { lhe dê auto-continência, a fim de aliviar a ansiedade gerada pela folha em branco e pelas instruções. } \\
\text { 2. Negativo: família em expansão, em busca de limites. Defeito de continência, perda de coesão. Tipo } \\
\text { de defesa: luta contra o vazio. }\end{array}$ \\
\hline
\end{tabular}




\begin{tabular}{|c|c|c|}
\hline & & Positivo: abertura ao exterior, riqueza fantasmática. \\
\hline $\begin{array}{l}\text { 56. Qual é o primeiro elemento } \\
\text { desenhado }\end{array}$ & $\begin{array}{l}\text { 1. Contorno, janelas, telhado, porta de } \\
\text { entrada (elementos da fachada) } \\
\text { 2. Cômodos internos } \\
\text { 3. Elementos de circulação interior } \\
\text { (corredores, escadas, elevador) } \\
\text { 4. Objetos interiores (móveis, quadros, } \\
\text { objetos decorativos) } \\
\text { 5. Elementos exteriores }\end{array}$ & $\begin{array}{l}\text { 1. Promove um continente antes de um conteúdo (eu-pele, cf: Anzieu), revelando boa habilidade de } \\
\text { para-excitação (envelope familiar continente e protetor). } \\
\text { 2. Revela uma falha de continência do envelope familiar, menos proteção pelo acesso direto à } \\
\text { privacidade (a qualificar de acordo com o cômodo desenhado primeiro) } \\
\text { 3. Revela uma falha de continência do envelope familiar. } \\
\text { Destaque às alianças psíquicas entre os membros. } \\
\text { Lugares de conversação: o que é dito entre } 2 \text { portas. } \\
\text { 4. Revela uma falha de continência do envelope familiar: } \\
\text { Inversão do continente e do conteúdo. A superfície da inscrição é posta em evidência (cf. Eu-pele de } \\
\text { Anzieu). Sinal de personalização. Objeto icônico, egocêntrico, sagrado que contém a totalidade o } \\
\text { desenho, concentra qualquer elemento de continência. Paradigma da metonímia. } \\
\text { 5. Defesa, a família começa com o que envolve menos, pelo mais social, colocar-se em representação. }\end{array}$ \\
\hline $\begin{array}{l}\text { 57. Por quem é desenhado o } \\
\text { primeiro elemento }\end{array}$ & $\begin{array}{l}\text { 1. Pai } \\
\text { 2. Mãe } \\
\text { 3. Filho } \\
\text { 4. Avós } \\
\text { 5. Parentes } \\
\text { 6. Sogros } \\
\end{array}$ & Papel do porta-voz ou portado-sintoma da família. \\
\hline $\begin{array}{l}\text { 58. Qual é o último elemento } \\
\text { desenhado }\end{array}$ & $\begin{array}{l}\text { 1. Contorno, janelas, telhado, porta de } \\
\text { entrada (elementos da fachada) } \\
\text { 2. Cômodos internos } \\
\text { 3. Elementos de circulação interior } \\
\text { (corredores, escadas, elevador) } \\
\text { 4. Objetos interiores (móveis, quadros, } \\
\text { objetos decorativos) } \\
\text { 5. Elementos exteriores } \\
\text { 6. Assinatura }\end{array}$ & $\begin{array}{l}\text { Refere-se à dinâmica de fechamento do desenho } \\
\text { (Ver a questão 55) }\end{array}$ \\
\hline $\begin{array}{l}\text { 59. Por quem é o último elemento } \\
\text { desenhado? }\end{array}$ & $\begin{array}{l}\text { 1. Pai } \\
\text { 2. Mãe } \\
\text { 3. Filho } \\
\text { 4. Avós } \\
\text { 5. Parentes } \\
\text { 6. Sogros }\end{array}$ & $\begin{array}{l}\text { Papel de monitoramento, controle } \\
\text { Vontade de existir } \\
\text { Qualificar de acordo com a dinâmica do desenho }\end{array}$ \\
\hline $\begin{array}{l}\text { 60. Existe um espaço indefinido } \\
\text { (vazio, buraco) }\end{array}$ & Sim/Não & Evoca o impensável (transgeracional), segredo \\
\hline $\begin{array}{l}\text { 61. Qual é o primeiro cômodo } \\
\text { desenhado }\end{array}$ & & $\begin{array}{l}\text { Lugar de preocupação significativa de sua função ou lugar inconsciente na dinâmica familiar. É } \\
\text { importante ver onde este cômodo está localizado espacialmente. }\end{array}$ \\
\hline
\end{tabular}




\begin{tabular}{|c|c|c|}
\hline \multicolumn{3}{|l|}{$\begin{array}{l}\text { 62. Se outro primeiro cômodo, } \\
\text { especifique }\end{array}$} \\
\hline $\begin{array}{l}\text { 63. Por quem é desenhado o } \\
\text { primeiro cômodo }\end{array}$ & $\begin{array}{l}\text { 1. Pai } \\
\text { 2. Mãe } \\
\text { 3. Filho } \\
\text { 4. Avós } \\
\text { 5. Parentes } \\
\text { 6. Sogros } \\
\end{array}$ & Papel do porta-voz ou porta-sintoma da família \\
\hline $\begin{array}{l}\text { 64. Qual é a último cômodo } \\
\text { desenhado }\end{array}$ & & $\begin{array}{l}\text { É importante ver onde este cômodo está localizado espacialmente (na periferia ou no centro?) para dar } \\
\text { sentido a ele. } \\
\text { Ideia de fechar o desenho }\end{array}$ \\
\hline \multicolumn{3}{|l|}{ 65. Se outro, especifique } \\
\hline $\begin{array}{l}\text { 66. Quem desenha o último } \\
\text { cômodo }\end{array}$ & $\begin{array}{l}\text { 1. Pai } \\
\text { 2. Mãe } \\
\text { 3. Filho } \\
\text { 4. Avós } \\
\text { 5. Parentes } \\
\text { 6. Sogros }\end{array}$ & $\begin{array}{l}\text { Papel de monitoramento, controle } \\
\text { Vontade de existir } \\
\text { Qualificar de acordo com a dinâmica do desenho }\end{array}$ \\
\hline 67. Qual é o maior cômodo & & $\begin{array}{l}\text { Importante para o grupo familiar. Para ser analisado de acordo com o simbolismo do lugar (ver item } \\
43 \text { ) }\end{array}$ \\
\hline \multicolumn{3}{|l|}{ 68. Se outro, especificar } \\
\hline 69. Qual é o menor cômodo & & Para ser analisado de acordo com o cômodo: lugar pouco investido, ou que evoca a intimidade \\
\hline \multicolumn{3}{|l|}{ 70. Se outro, especificar } \\
\hline $\begin{array}{l}\text { 71. Qual cômodo contém mais } \\
\text { itens }\end{array}$ & & $\begin{array}{l}\text { Cômodo mais investido ou mais vivo. Analisar de acordo com o simbolismo do lugar. Evoca as } \\
\text { camadas de inscrição (Anzieu). Objetos são ligações simbólicas }\end{array}$ \\
\hline \multicolumn{3}{|l|}{ 72. Se outro cômodo, especificar } \\
\hline $\begin{array}{l}\text { 73. Qual cômodo contém o menor } \\
\text { número de objetos }\end{array}$ & & $\begin{array}{l}\text { Desinvestimento } \\
\text { Cômodos vazios: Pobreza imaginária, pensamento operativo, pouco investimento de relações objetais. } \\
\text { Sinal de depressão. Desvitalização. }\end{array}$ \\
\hline \multicolumn{3}{|l|}{ 74. Se outro cômodo, especificar } \\
\hline $\begin{array}{l}\text { 75. Que cômodo(s) contém objetos } \\
\text { herdados da linhagem paterna }\end{array}$ & & Lugar da história familiar inter e transgeracional no lado paterno, dominante ou isolado? \\
\hline \multicolumn{3}{|l|}{ 76. Se outro quarto especificar } \\
\hline $\begin{array}{l}\text { 77. Que cômodo(s) contém objetos } \\
\text { herdados da linhagem materna }\end{array}$ & & Lugar da história familiar inter e transgeracional no lado materno, dominante ou isolado? \\
\hline \multicolumn{3}{|l|}{ 78. Se outro cômodo, especifique } \\
\hline $\begin{array}{l}\text { 79. Qual é o cômodo onde é } \\
\text { agradável ficarem juntos? }\end{array}$ & & $\begin{array}{l}\text { Fantasia do corpo comum: lugar de fusão entre os membros, a interpretar de acordo com o simbolismo } \\
\text { do lugar, e respeito à lei da proibição do incesto. }\end{array}$ \\
\hline
\end{tabular}




\begin{tabular}{|c|c|c|}
\hline & & Revela a existência e a qualidade da ilusão grupal. \\
\hline 80. Se outro cômodo, especificar & & A especificar de acordo com o simbolismo do cômodo \\
\hline $\begin{array}{l}\text { 81. Qual é o cômodo onde o pai } \\
\text { gosta de ficar sozinho? }\end{array}$ & & $\begin{array}{l}\text { Cômodo que assume significado em conexão com a função paterna. Lugar de personalização da função } \\
\text { paterna. } \\
\text { O cômodo onde gostamos de ficar sozinhos evoca a função autoerótica, no âmbito pulsional. }\end{array}$ \\
\hline 82. Se outro cômodo, especificar & & A especificar de acordo com o simbolismo do cômodo \\
\hline $\begin{array}{l}\text { 83. Qual é a cômodo onde a mãe } \\
\text { gosta de ficar sozinha? }\end{array}$ & & $\begin{array}{l}\text { Cômodo que assume significado em conexão com a função materna } \\
\text { Lugar de personalização da função materna } \\
\text { O cômodo onde gostamos de ficar sozinhos evoca a função autoerótica, no âmbito pulsional }\end{array}$ \\
\hline 84. Se outro cômodo, especificar & & A especificar de acordo com o simbolismo do cômodo \\
\hline $\begin{array}{l}\text { 85. Qual é o cômodo onde o } \\
\text { filho(a) gosta de ficar sozinho? }\end{array}$ & & $\begin{array}{l}\text { Possibilidade de estar sozinho ou autônomo. } \\
\text { Capacidade da família de privilegiar o modo diferenciado de se relacionar. } \\
\text { O cômodo onde gostamos de ficar sozinhos evoca a função autoerótica, no âmbito pulsional }\end{array}$ \\
\hline 86. Se outro cômodo, especificar & & A especificar de acordo com o simbolismo do cômodo \\
\hline $\begin{array}{l}\text { 87. Existe um cômodo } \\
\text { permanentemente ocupado por } \\
\text { avós ou outra pessoa da família? }\end{array}$ & Sim/Não & $\begin{array}{l}\text { Existência de várias gerações sob o mesmo teto. } \\
\text { Não há separação. Solidariedade fusional. } \\
\text { Representação forte do intergeracional. } \\
\text { A configuração dos cômodos indica a qualidade das relações geracionais. }\end{array}$ \\
\hline $\begin{array}{l}\text { 88. Em qual cômodo dá a porta da } \\
\text { frente }\end{array}$ & & $\begin{array}{l}\text { Porta de entrada: papel da fronteira entre o interior e o exterior. Interpretar de acordo com o significado } \\
\text { simbólico do cômodo: se é uma cômodo de recepção (lógico) ou se é um cômodo íntimo (ilógico) }\end{array}$ \\
\hline 89. Se outro, especificar & & \\
\hline $\begin{array}{l}\text { 90. Ausência de porta interior: em } \\
\text { que cômodo }\end{array}$ & & $\begin{array}{l}\text { A ausência de uma porta remove a intimidade da cômodo, mas também sua especificidade. Problema } \\
\text { da diferenciação de espaços. Revela um corpo familiar comum indiferenciado. }\end{array}$ \\
\hline 91. Se outro, especificar & & \\
\hline 92. Ausência de corredor & Sim/Não & $\begin{array}{l}\text { Sim: Ausência de circulação de fantasia, comunicação entre lugares, de ligações. Revela } \\
\text { indiferenciação (pólo isomórfico familiar predominante) } \\
\text { Não: Lugares de passagem, de circulação, espaços de transição, entre-dois }\end{array}$ \\
\hline 93. Ausência de porta de entrada & Sim/Não & $\begin{array}{l}\text { Sim: Informa sobre as dificuldades de comunicação com o exterior, funcionamento defensivo } \\
\text { autárquico. } \\
\text { Pode ser relativizado, se existir um quarto de hóspedes. } \\
\text { Não: Local oficial de contato com o mundo }\end{array}$ \\
\hline 94. Ausência de janelas & Sim/Não & $\begin{array}{l}\text { Sim: Informa sobre a abertura para o mundo exterior. Coloca em questão a qualidade do envelope: a } \\
\text { falta de janelas pode evocar a constituição de um "envelope carapaça" pela família. Por outro lado, o } \\
\text { excesso de janelas pode implicar um enfraquecimento do envelope, o que promove confusão } \\
\text { interior/exterior. A dimensão escópica enfatiza a questão de ver e ser visto, a intimidade em relação ao } \\
\text { mundo exterior. Questão do voyeurismo e exibicionismo. } \\
\text { Não: Vínculo com a realidade }\end{array}$ \\
\hline
\end{tabular}




\begin{tabular}{|c|c|c|}
\hline $\begin{array}{l}95 . \quad \text { Outra } \text { abertura não } \\
\text { convencional (a. acesso de luz, } \\
\text { claraboias; b. túnel, portão, } \\
\text { orifício) }\end{array}$ & & $\begin{array}{l}\text { - Originalidade } \\
\text { a. Manifestação da pulsão de vida; mas, ao extremo, muita luz é despersonalizante. } \\
\text { Defesa reacional à depressão (deixar entrar a luz). Defesa fóbica contra ansiedade, o escuro. Negação } \\
\text { de limites. Onipresença (estar em mais de um lugar ao mesmo tempo). Ausência de fronteiras. } \\
\text { b. Túnel, porta do animal de estimação, orifício: necessidade oculta de proteção. Ligação com o } \\
\text { inconsciente. }\end{array}$ \\
\hline 96. Escadaria interior & Sim/Não & $\begin{array}{l}\text { Sim: A escada é uma representação da relação entre gerações. } \\
\text { Capacidade de fazer conexões flexíveis. Capacidade de mudar de nível psíquico, movendo-se de uma } \\
\text { instância para outra. } \\
\text { Associação entre a experiência física e a experiência psíquica. } \\
\text { Não: Compartimentalização psíquica, se há ausência de escadas (aproximação entre as instâncias } \\
\text { psíquicas: cf. andares) }\end{array}$ \\
\hline 97. Escada e/ou elevador exterior & Sim/Não & $\begin{array}{l}\text { Sim: Defesa contra ficar preso. Ambivalência em torno da capacidade de continência da casa. } \\
\text { Necessidade ansiosa de uma saída de emergência. }\end{array}$ \\
\hline 98. Elementos anexos à casa & $\begin{array}{l}\text { 1. Garagem } \\
\text { 2. Ateliê } \\
\text { 3. Jardim } \\
\text { 4. Horta } \\
\text { 5. Piscina } \\
\text { 6. Nenhum } \\
\text { 7. Outro edifício (cf. 98) }\end{array}$ & $\begin{array}{l}\text { Qualificar conforme a presença ou ausência de um plano interior. } \\
\text { Os anexos são expansões do corpo (sonhos não realizados). } \\
\text { Os elementos contíguos: prolongamento narcísico do corpo familiar para reforçar a para-excitação (eu- } \\
\text { pele), extensão narcísica. } \\
\text { Os elementos à distância da casa: reforçam a dimensão objetal, autonomia em relação ao corpo } \\
\text { familiar. }\end{array}$ \\
\hline 99. Se outro edifício, especificar & & Interpretar de acordo com a problemática da família \\
\hline 100. Decorações exteriores & Sim/Não & $\begin{array}{l}\text { Abertura ao exterior, imaginário a qualificar de acordo com a presença ou não de um plano interior. } \\
\text { Imagem narcisista que a família expõe. }\end{array}$ \\
\hline $\begin{array}{l}\text { 101. Se outras decorações, } \\
\text { especificar }\end{array}$ & & Interpretar de acordo com a problemática da família \\
\hline $\begin{array}{l}\text { 102. Existem indicações de } \\
\text { posição geográfica? }\end{array}$ & Sim/Não & $\begin{array}{l}\text { Sim: Necessidade de pontos de referência (de identidade, emocionais, relacionais). Questões espaciais } \\
\text { referem-se às problemáticas simbólicas do lugar na família. A família precisa se apoiar sobre o } \\
\text { ambiente externo. }\end{array}$ \\
\hline $\begin{array}{l}\text { 103. A família desenhou a sua casa } \\
\text { atual? }\end{array}$ & Sim/Não & $\begin{array}{l}\text { Sim: Conformidade, apoio ao real, resistência às instruções, imaginação empobrecida, pensamento } \\
\text { operacional, estereotipia. } \\
\text { Não: Capacidade de fantasiar, criatividade, imaginação expandida, aceitação de instruções, } \\
\text { compensação da realidade }\end{array}$ \\
\hline $\begin{array}{l}\text { Para a leitura dos seguintes itens: } \\
\text { interpretar de acordo com a } \\
\text { estrutura inconsciente da } \\
\text { organização familiar (narcisista, } \\
\text { anaclítica, edipiana) }\end{array}$ & & $\begin{array}{l}\text { Narcisista: busca de um duplo de si mesmo, de uma idealização (casa ideal, perfeita, que se parece com } \\
\text { eles) } \\
\text { Casa percebida como uma torre de marfim: autarquia, ideia de superioridade. } \\
\text { Anaclítica: busca de um apoio na casa, a família sofre a falta, aceita buscar complementaridade em sua } \\
\text { casa (ex: precisa de segurança em toda a casa, "uma casa sólida") }\end{array}$ \\
\hline
\end{tabular}




\begin{tabular}{|c|c|c|}
\hline & & $\begin{array}{l}\text { Casa percebida como refúgio: ideia de proteção. } \\
\text { Edipiana: família que está em castração. Casa serve para destacar o sucesso social, a casa como um } \\
\text { exemplo de sucesso fálico. Idéia de luta, rivalidade: "melhor que", sedução (para seduzir alguém) }\end{array}$ \\
\hline $\begin{array}{l}\text { 104. Se não: Em que a casa é } \\
\text { imaginária? }\end{array}$ & & Fornece informações sobre temas (desejos e medos imaginários) fantasmáticos da família \\
\hline $\begin{array}{l}\text { 105. O que a família pensa de seu } \\
\text { desenho? } \\
\text { (Considere a opinião do grupo e } \\
\text { não a opinião individual) }\end{array}$ & $\begin{array}{l}\text { 1. Muito satisfeita } \\
\text { 2. Satisfeita } \\
\text { 3. Sem opinião } \\
\text { 4. Pouco satisfeita } \\
\text { 5. Muito insatisfeita } \\
\text { 6. Sem acordo comum }\end{array}$ & $\begin{array}{l}\text { O que as famílias pensam sobre o desenho é sua própria representação de si mesmas. } \\
\text { Mede o grau de autossatisfação de sua produção. } \\
\text { Especifica a qualidade da ilusão grupal. } \\
\text { 6. Discordância no grupo, corpo familiar rachado. }\end{array}$ \\
\hline 106. A que se referem? & $\begin{array}{l}\text { 1. Solidez } \\
\text { Respostas: parede, telhado, quadro, } \\
\text { fundação } \\
\text { 2. Decoração } \\
\text { Respostas: móveis, quadros, cores, } \\
\text { objetos. } \\
\text { 3. Espaço, circulação } \\
\text { Respostas: porta, escada, espaços } \\
\text { intermediáros (corredores) variação das } \\
\text { proporções dos cômodos. } \\
\text { 4. Experiência sensorial } \\
\text { Respostas relacionadas à experiência } \\
\text { bruta, à sensação corporal, tudo o que está } \\
\text { perto do corpo: "jacuzi", "piscina", } \\
\text { "sauna", "lareira", "aquecimento", } \\
\text { "painéis solares", "fonte", "banheira", } \\
\text { "ventilador", "ar condicionado" } \\
\text { 5. Espaços de organização } \\
\text { Armários, despensa, adega } \\
\text { 6. Nada para refazer } \\
\text { 7. Refazer tudo }\end{array}$ & $\begin{array}{l}\text { Possibilita avaliar as necessidades e a fragilidade da imagem do corpo em seus níveis básicos, erógenos } \\
\text { e funcionais. } \\
\text { 1. Qualifica a imagem do corpo básico (imagem de segurança, mapa topográfico de Dolto, 1984). } \\
\text { Necessidade de fortalecer os limites do envelope familiar (barreira de para-excitação) (Anzieu). Avalia } \\
\text { a qualidade da continência da família. } \\
\text { 2. As respostas de decoração servem ao nível de apego aos objetos. Evocam a camada interna da } \\
\text { inscrição simbólica (Anzieu), os afetos, mas também à relação objetal. Identidade comum } \\
\text { insatisfatória, daí a necessidade de retrabalhar a representação da imagem da família. } \\
\text { 3. As respostas de Espaço-Circulação atendem ao nível dinâmico da imagem do corpo funcional ("que } \\
\text { traz à ação e que estabelece relações com seu ambiente", Dolto, 1984). Conscientização de uma barreira } \\
\text { de comunicação entre os membros da família. A presença de corredor e escada e controle com as portas } \\
\text { sinalizam uma boa circulação psíquica entre os membros. Uma nota sobre a necessidade de mais } \\
\text { 'armários, armazenamento ", o que implica uma noção de inclusão. O armário é um lugar paradoxal, } \\
\text { que implica não desejarmos ser incomodados por um objeto, mas guardá-lo ("um interior dentro do } \\
\text { interior", Cuynet, 2013). } \\
\text { 4. As respostas "Experiências sensoriais" servem ao nível pulsional da imagem do corpo erógeno } \\
\text { ("lugar em que prazer e desprazer erotizam a relação com o outro", Dolto, 1984). Se há uma fixação } \\
\text { importante na experiência corporal: evoca uma falha de mentalização, favorável ao terreno das doenças } \\
\text { psicossomáticas. Tendência a relações fusionais, clima incestuoso, presença mais ou menos forte da } \\
\text { lei. } \\
\text { 5. Processo de repressão para manter a homeostase familiar } \\
\text { 6. Autossatisfação revela a ilusão narcísica grupal dentro da família. Imaginação empobrecida. Rigidez } \\
\text { psíquica. } \\
\text { 7. Eu-ideal familiar opressivo (insatisfação ligada a um ideal nunca satisfeito). Baixa autoestima do } \\
\text { "eu familiar" melancólico. Superego: coloca-se numa experiência de fracasso. }\end{array}$ \\
\hline $\begin{array}{l}\text { 107. Onde é o lugar mais } \\
\text { importante na folha }\end{array}$ & $\begin{array}{l}\text { 1. Em volta } \\
\text { 2. Exterior } \\
\text { 3. Sem escolha comum }\end{array}$ & $\begin{array}{l}\text { Avalia o nível de segurança interna da família. } \\
\text { Quanto mais a escolha estiver na periferia, menor o nível de agrupamento e a segurança interna será } \\
\text { baixa. }\end{array}$ \\
\hline
\end{tabular}




\begin{tabular}{|c|c|c|}
\hline & $\begin{array}{l}\text { 4. Interior } \\
\text { 5. Outro }\end{array}$ & $\begin{array}{l}\text { A resposta "a casa inteira" apontaria para um processo de não-discriminação e, portanto, de não- } \\
\text { diferenciação. } \\
\text { 1. Deslocamento do eu-familiar para a periferia do self familiar. Excesso de investimento do limite. } \\
\text { Discordância, estado-limite, paradoxalidade. } \\
\text { 2. Falta de continência do envelope familiar. Impossibilidade do grupo para permanecer em casa. } \\
\text { Efeito da despersonalização da família (ela não se reconhece na casa). } \\
\text { 3. Ausência de espírito de grupo, falta de coesão: nenhuma ilusão grupal. } \\
\text { 4. Possibilidade de projetar a interioridade e intimidade no grupo familiar, revelando um nível } \\
\text { suficiente de segurança interna da família. } \\
\text { 5. O significado depende do simbolismo do cômodo. }\end{array}$ \\
\hline 108. Se outro, especificar & & $\begin{array}{l}\text { De acordo com o simbolismo do lugar. } \\
\text { Pátio: lugar paradoxal, tanto de dentro quanto de fora, revelando uma fuga da família para o } \\
\text { relacionamento com outros. }\end{array}$ \\
\hline $\begin{array}{l}\text { 109. Qual é o lugar mais } \\
\text { importante da casa }\end{array}$ & & $\begin{array}{l}\text { Localização relacionada à sua funcionalidade. Evoca a identidade. A escolha do lugar seria indicativa } \\
\text { do investimento pulsional da família e da fixação ou não em certas etapas: Oral, anal, pré-edípica, pré- } \\
\text { genital, fálica. } \\
\text { As respostas permitem igualmente: } \\
\text { - Estudar o polo predominante na família (isomorfismo/homomorfia) em função do símbolo do cômodo } \\
\text { (individual ou coletivo). } \\
\text { - Medir o nível de angústia (ruptura ou sufocamento, fusão) } \\
\text { - Se a escolha comum se refere a um espaço individual: relação paradoxal, tendência à confusão. }\end{array}$ \\
\hline \multicolumn{3}{|r|}{ 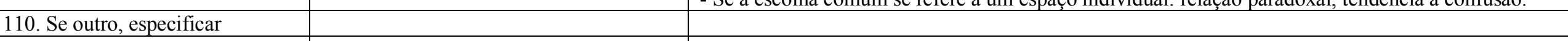 } \\
\hline $\begin{array}{l}\text { 111. O que caracteriza sua família } \\
\text { neste desenho da casa }\end{array}$ & $\begin{array}{l}\text { 1. Manutenção } \\
\text { Exemplos de respostas: "O quadro", } \\
\text { "estrutura metálica", "Arquitetura", "A } \\
\text { solidez" } \\
\text { 2. Continência } \\
\text { Exemplos de respostas: "Conforto", } \\
\text { "Atmosfera calorosa", "Todos } \\
\text { participaram", "Estar perto de uma mesa", } \\
\text { "Nós não estamos separados", "Sofá } \\
\text { grande", "Recantos e fendas" } \\
\text { 3. Para-excitação e filtragem } \\
\text { Proteção de casa (paredes, janelas, } \\
\text { portas), espessura de parede } \\
\text { "Bom isolamento" etc. } \\
\text { 4. Individualização } \\
\text { Lugares personalizados para cada um }\end{array}$ & $\begin{array}{l}\text { Este item se refere a como a família se define e à qualidade do envelope familiar. As categorias de } \\
\text { interpretação propostas referem-se às funções do eu-pele familiar (ver Anzieu), sabendo que cada uma } \\
\text { pode ter uma polaridade negativa ou positiva. Exemplos de respostas são dadas em cada categoria (uma } \\
\text { resposta pode corresponder a várias funções). } \\
\text { 1. Respostas que evocam elementos estruturais: ideia de suporte, solidez } \\
\text { 2. O que mantém as pessoas juntas, o que fornece um envelope. } \\
\text { 3. Evoca as capacidades de filtragem e proteção, a ideia de deixar entrar o que é bom e manter fora o } \\
\text { que é ruim } \\
\text { 4. Reconhecimento da individualidade de cada pessoa pelos lugares identificados } \\
\text { 5. Consenso, conexão entre todos os membros em um fundo familiar comum que os unifica: é o âmbito } \\
\text { emocional que conecta, "nós gostamos de ficar juntos" } \\
\text { 6. Enriquecimento de se sentir junto, fortalece o self familiar, não evoca a sexualidade } \\
\text { 7. Enriquecimento de se sentir junto, fortalece o self familiar, não evoca a sexualidade } \\
\text { 8. Evoca a camada de inscrição (decoração interior: objetos de decoração, móveis, fotos) } \\
\text { Ideia de personalização do habitat interior, memória histórica }\end{array}$ \\
\hline
\end{tabular}




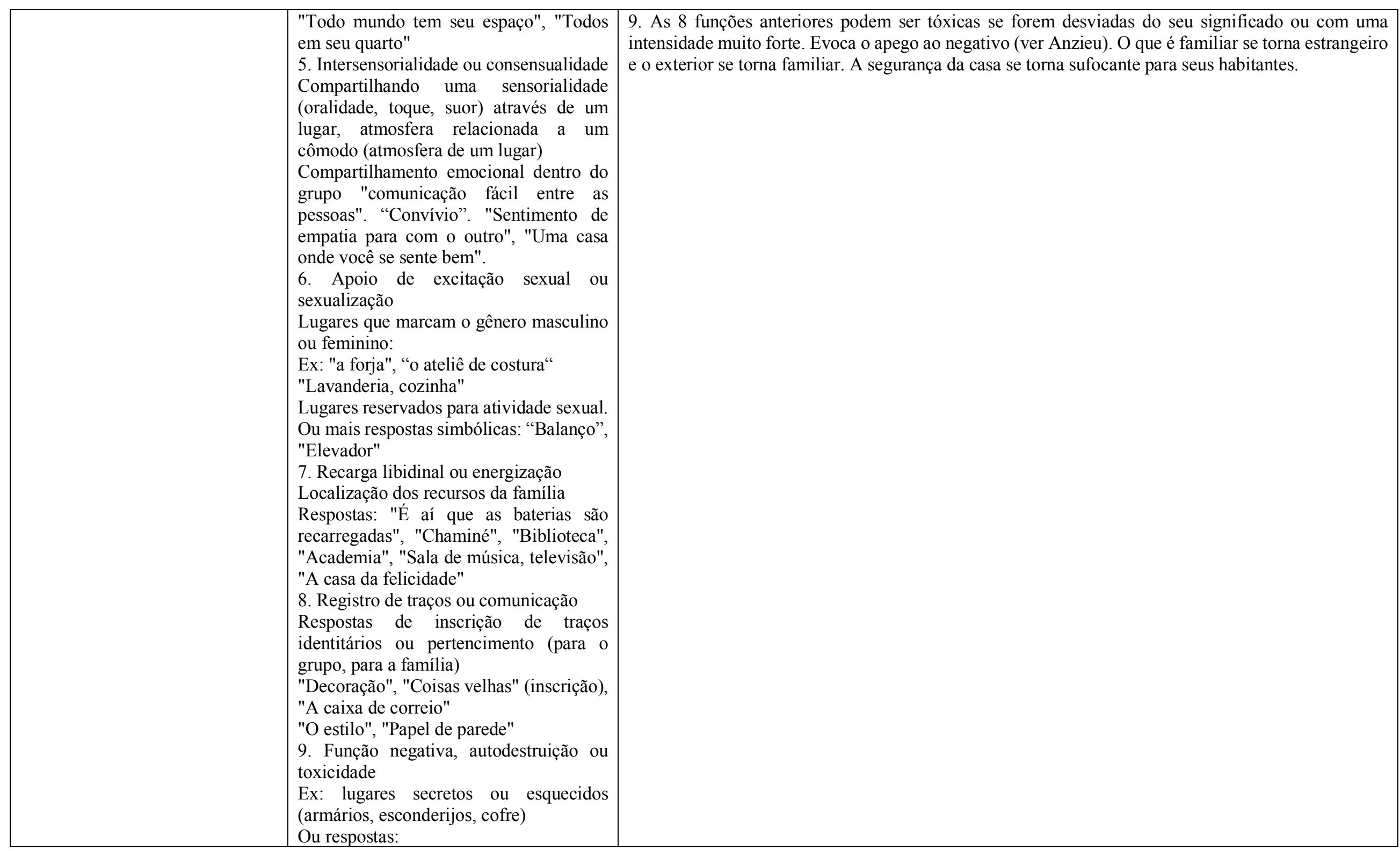




\begin{tabular}{|c|c|c|}
\hline & $\begin{array}{l}\text { "Casa podre por dentro" "bomba-relógio" } \\
\text { "ruína", "triste", "esta casa nos culpa", } \\
\text { "desordem" }\end{array}$ & \\
\hline $\begin{array}{l}\text { 112. De que materiais esta casa } \\
\text { seria feita e por quê }\end{array}$ & $\begin{array}{l}\text { 1. Sólido } \\
\text { 2. Macio e resistente } \\
\text { 3. Frágil }\end{array}$ & $\begin{array}{l}\text { Este item relativo aos materiais evoca o conceito e qualidade de para-excitação, e ajuda a avaliar a } \\
\text { qualidade do envelope grupal familiar, a necessidade compensatória ou não sentida pela família. } \\
\text { Interpretação da flexibilidade ou não do envelope grupal segundo o discurso da família. } \\
\text { 1. Família anaclítica: busca de uma base segura e de um envelope que funciona como carapaça em } \\
\text { reação a um baixo nível de segurança interna. } \\
\text { Família narcisista: sólida na imagem da força familiar. } \\
\text { 2. Experiência calorosa pela madeira e flexibilidade do envelope. } \\
\text { 3. Fragilidade do envelope, originalidade, singularidade Envelope evanescente: eu inconsistente. } \\
\text { Paradoxalmente: eu sólido e grandioso, que não precisa de proteção ou abrigo (dormindo sob as } \\
\text { estrelas) (família narcisista, nômade) }\end{array}$ \\
\hline $\begin{array}{l}\text { 113. Qual é a cor desta casa por } \\
\text { fora (acordo do grupo familiar em } \\
\text { uma cor) }\end{array}$ & $\begin{array}{l}\text { 1. Cor escura } \\
\text { 2. Cor clara } \\
\text { 3. Cor pastel } \\
\text { 4. Cor viva }\end{array}$ & $\begin{array}{l}\text { 1. Estudo da pulsionalidade e da afetividade } \\
\text { As cores referem-se à camada de inscrição (Anzieu). A cor exterior escolhida está relacionada à } \\
\text { representação social que a família deseja dar a si mesma. Estudo de um tom depressivo ou não. } \\
\text { Escuro: Valência Depressiva. Particularidade do preto: mortal } \\
\text { 2. Leve noção de sentimentalismo. } \\
\text { Particularidade do branco: afeto Afetividade, com vazio e transparência, ideia de assepsia } \\
\text { 3. Cor pastel: discrição, pouca afirmação } \\
\text { 4. Cor viva: assertividade franca, agressividade, advertência }\end{array}$ \\
\hline $\begin{array}{l}\text { 114. Qual é a cor desta casa por } \\
\text { dentro }\end{array}$ & $\begin{array}{l}\text { 1. Cor escura } \\
\text { 2. Cor clara } \\
\text { 3. Cor pastel } \\
\text { 4. Cor viva }\end{array}$ & $\begin{array}{l}\text { A cor interior escolhida refere-se ao tom interno afetivo (a experiência interna do self familiar refere- } \\
\text { se à pulsionalidade da família). } \\
\text { Para interpretar esta questão, é interessante focar no contraste interno/externo: } \\
\text { - Se existe coerência entre o interior e o exterior: homogeneidade } \\
\text { - Se há discordância, bipolaridade do humor: um excesso de cor clara no exterior é uma defesa contra } \\
\text { uma depressão interna. As cores brilhantes no interior referem-se a uma forte pulsionalidade escondida } \\
\text { por um exterior opaco. Estudo de um tom depressivo ou não. } \\
\text { Escuro: Valência Depressiva. Particularidade do preto: mortal. } \\
\text { Particularidade do branco: Problema de um desafeto, noção de vazio e transparência, ideia de assepsia } \\
\text { Cor pastel: pouca auto-confiança } \\
\text { Cor brilhante: afirmação franca e pulsionalidade mal controlada }\end{array}$ \\
\hline $\begin{array}{l}\text { 115. Imagine um desastre em sua } \\
\text { casa, qual seria o objetivo de } \\
\text { salvar primeiro? (Um objeto em } \\
\text { comum) }\end{array}$ & $\begin{array}{l}\text { 1. Objeto herdado } \\
\text { Objetos de gerações anteriores (álbuns de } \\
\text { fotos, árvore genealógica, caixa de } \\
\text { música) } \\
\text { 2. Objeto adquirido } \\
\text { Computador, televisão (objetos modernos } \\
\text { adquiridos pela família) }\end{array}$ & $\begin{array}{l}\text { 1. Evidencia a família em uma situação crítica ou de emergência. Avalia sua capacidade de responder } \\
\text { ou pensar a perda. } \\
\text { Dependendo do objeto escolhido, diferentes significados podem ser pensados: } \\
\text { - se de ordem atual e utilitária } \\
\text { - de ordem emocional } \\
\text { - se da ordem da memória e da identidade } \\
\text { 2. Missão e peso dos mitos familiares. Lealdade, identidade apoiada no passado }\end{array}$ \\
\hline
\end{tabular}




\begin{tabular}{|c|c|c|}
\hline & $\begin{array}{l}\text { 3. Objeto de suporte identitário } \\
\text { Documentos de identidade, documentos } \\
\text { administrativos } \\
\text { 4. Objeto neutro } \\
\text { Objetos sem valor sentimental } \\
\text { 5. Objeto de utilidade } \\
\text { Colchão, geladeira, fogão } \\
\text { 6. Objeto afetivo } \\
\text { Fotos, joias, objetos investidos de carinho } \\
\text { 7. Impossibilidade de responder }\end{array}$ & $\begin{array}{l}\text { Proteger o eu familiar nestas realizações atuais } \\
\text { 3. Proteger a identidade simbólica e social } \\
\text { 4. Operacional, afastada dos afetos } \\
\text { 5. Operacional, concreto } \\
\text { 6. Salvaguardar o vínculo de apego objetal (em relação a alguém } \\
\text { 7. Evidência de fragilidade na família. Risco de colapso psíquico subjacente. } \\
\text { Naufrágio, perda impensável ou pânico. }\end{array}$ \\
\hline $\begin{array}{l}\text { 116. Onde este objeto estaria no } \\
\text { desenho? }\end{array}$ & & $\begin{array}{l}\text { O objeto está localizado em um ponto estratégico da casa, em um dos quartos mais investidos pela } \\
\text { família? Estaria escondido ou à vista de todos? Podemos considerar que quanto mais o objeto é } \\
\text { colocado longe do centro na casa, menos valioso ou protegido seria. }\end{array}$ \\
\hline 117. Especifique o local, se outro & & \\
\hline $\begin{array}{l}\text { 118. Qual é a qualidade essencial } \\
\text { de uma casa para você? }\end{array}$ & $\begin{array}{l}\text { 1. Manutenção } \\
\text { 2. Continência } \\
\text { 3. Para-excitação e filtragem } \\
\text { 4. Individualização } \\
\text { 5. Intersensorialidade ou consensualidade } \\
\text { 6. Apoio de excitação sexual ou } \\
\text { sexualização } \\
\text { 7. Recarga libidinal ou energização } \\
\text { 8. Registro de traços ou comunicação } \\
\text { 9. Função negativa, autodestruição ou } \\
\text { toxicidade }\end{array}$ & $\begin{array}{l}\text { Estar atento a essa questão é importante. Ele fornece informações sobre: } \\
\text { - A ideologia familiar (grandes princípios, eu-ideal) } \\
\text { - A problemática, as ansiedades, as defesas da família, o que faz falta à família (busca por reparo, } \\
\text { preenchimento) } \\
\text { - A função continente ou não do envelope (necessidade de segurança, ideia de continência, envelope) } \\
\text { As interpretações desses itens, portanto, implicam as diferentes categorias do eu-pele. } \\
\text { 1. Evoca elementos estruturais: ideia de suporte, espaço funcional } \\
\text { 2. Evoca o envelope sólido delimitado. Material das paredes. } \\
\text { 3. Evoca as capacidades de filtragem e proteção, refúgio. } \\
\text { 4. Reconhecimento da individualidade de cada um, protege seus assuntos privados. } \\
\text { 5. Consenso entre todos os membros, eles formam corpo, cumplicidade, solidariedade. } \\
\text { 6. Evoca o corpo sexual dos membros, intimidade, a diferença sexual é marcada. } \\
\text { 7. Enriquecimento de se sentir junto, fortalece a identidade da famélia, não se evoca a sexualidade. } \\
\text { 8. Evoca a camada de inscrição (decoração interior: quadros, móveis, objetos). Idéia de personalização, } \\
\text { herança e memória } \\
\text { 9. As } 8 \text { funções anteriores podem ser tóxicas se forem desviados do seu significado ou intensidade } \\
\text { muito forte. Evoca o apego ao negativo (D. Anzieu) }\end{array}$ \\
\hline
\end{tabular}

